\title{
Cercospora zeae-maydis: ESPORULAÇÃO, DIVERSIDADE MORFO-GENÉTICA E REAÇÃO DE LINHAGENS DE MILHO
}

KÁTIA REGIANE BRUNELLI

Tese apresentada à Escola Superior de Agricultura "Luiz de Queiroz", Universidade de São Paulo, para obtenção do título de Doutor em Agronomia, Área de Concentração: Fitopatologia.

PIR A C I C A B A

Estado de São Paulo - Brasil

Agosto - 2004 


\section{Cercospora zeae-maydis: ESPORULAÇÃO, DIVERSIDADE MORFO-GENÉTICA E REAÇÃO DE LINHAGENS DE MILHO}

KÁTIA REGIANE BRUNELLI

Engenheiro Agrônomo

Orientador: Prof. Dr. LUIS EDUARDO ARANHA CAMARGO

Tese apresentada à Escola Superior de Agricultura "Luiz de Queiroz", Universidade de São Paulo, para obtenção do título de Doutor em Agronomia,

Área de Concentração:

Fitopatologia.

PIR A C I C A B A

Estado de São Paulo - Brasil

Agosto - 2004 


\section{Dados Internacionais de Catalogação na Publicação (CIP) DIVISÃO DE BIBLIOTECA E DOCUMENTAÇÃO - ESALQ/USP}

Brunelli, Kátia Regiane Cercospora zeae-maydis: esporulação, diversidade morfo-genética e reação de linhagens de milho / Kátia Regiane Brunelli. - - Piracicaba, 2004.

105 p. : il.

Tese (doutorado) - - Escola Superior de Agricultura Luiz de Queiroz, 2004.

Bibliografia.

1. Cercosporiose 2. Esporulação 3. Fungo fitopatogênico 4. Marcador molecular 5. Milho 6. Resistência genética vegetal I. Título

CDD 633.15

"Permitida a cópia total ou parcial deste documento, desde que citada a fonte - O autor" 
Aos meus "barulhentos" sobrinhos:

Isabela, Ana Carolina, Igor e Daniel

por encherem a vida de sons e cores

\section{Ofereço}

A meus pais, Manoel e Geni, pela presença e amor Dedico 


\section{AGRADECIMENTOS}

A Deus por estar comigo em todos os momentos.

À minha família, em especial a meus país Manoel e Geni, por transformarem nossa casa em um porto seguro.

Ao Prof. Dr. Luis Eduardo Aranha Camargo pelos anos de orientação, e pelo exemplo de dedicação científica e acadêmica.

Aos meus amigos Cândido Athayde Sobrinho, Rodrigo Rodrigues Matiello e Leonardo Sousa Cavalcanti pelas produtivas "discussões" científicas, pela cumplicidade e por tornarem eterna nossa amizade.

Às amigas Maria Teresa Gomes Lopes, Ana Paula Matoso Teixeira e Nilza Patrícia Ramos pela prontidão em compartilhar seus conhecimentos.

À Ana Carolina Fazza pelo auxílio na condução dos experimentos e a Daniel Rosa pelo auxílio nas análises de diversidade.

À Cláudia Vitorello pelo estímulo profissional e auxílio na elaboração do summary.

Aos colegas do Laboratório de Genética Molecular do Departamento de Fitopatologia: Daniela, Célia, Maria Teresa, Mariana, Rodrigo, Viviane, Ana Paula, Nilza Patrícia, Adriana, Alessandra, Paulo, Ana Carolina, Regina, Cláudia, Jorge, 
Herberte, Flávia, Maeli, Alice, Giovana, Maria Cristina, Osmar, Camila, Marcelo, Alessandra, Raphaelle, Ademir, Thayne, Juliana, Daniel, Sandra, Reinaldo e Fátima pela amizade e por tornarem tão alegre nosso ambiente de trabalho.

Aos colegas do curso de pós-graduação em Fitopatologia pelos bons momentos compartilhados.

Aos professores do Departamento de Fitopatologia da ESALQ-USP pelos ensinamentos e colaborações ao desenvolvimento deste trabalho.

Aos funcionários do Departamento de Fitopatologia Maria Heloisa, Fernanda, Rodolfo, Marina, Jefferson, Sr. Pedro, Marisa, Sílvia e Edivaldo pela amizade, ajuda e disponibilidade durante os anos que ali passei.

Aos Prof. Drs. Renzo Von Pinho (UFLA), Edward Brasil (UFG) e Cláudio Lopes (ESALQ-USP) pelas linhagens utilizadas neste estudo.

Ao Dr. Larry D. Dunkle da Purdue University (USA) pela gentileza em enviar os isolados padrões de Cercospora.

Ao Eng. Agrônomo Roberto V. Carvalho (Dow AgroSciences) por ser sempre solícito em contribuir para este trabalho.

À $\operatorname{Dr}^{a}$ Gisèle Maria Fantin e ao Dr. Aildson Pereira Duarte pelo envio de material vegetal para isolamento do fungo.

À Empresa de Sementes DowAgroSciences Ltda. por disponibilizar o campo experimental para a realização de parte deste trabalho.

À CAPES pela concessão da bolsa de estudo.

À ESALQ pelos anos de formação profissional. 


\section{SUMÁRIO}

Página

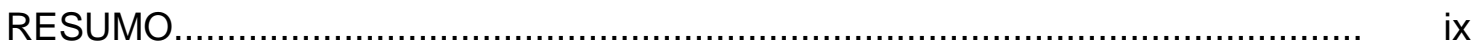

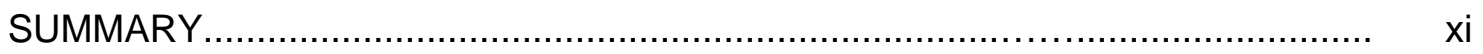

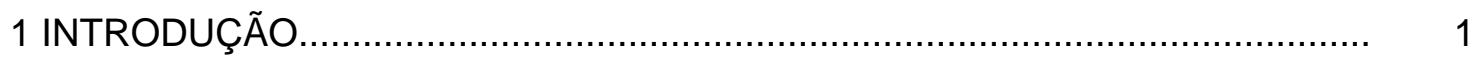

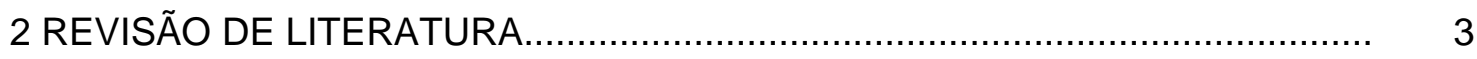

2.1 A cultura do milho no Brasil ............................................................. 3

2.2 A importância da mancha de cercospora e sintomatologia .......................... 4

2.3 Etiologia e condições predisponentes ..................................................... 5

2.4 Diversidade genética e morfológica de Cercospora zeae- maydis - os

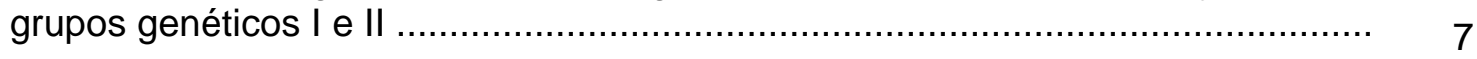

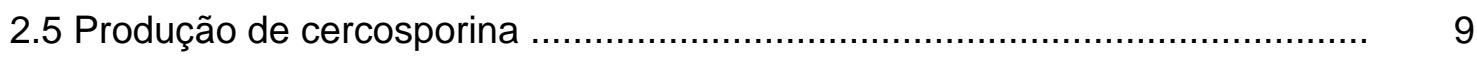

2.6 O fenômeno da conidiação microcíclica ................................................. 10

2.7 Controle da doença ..................................................................... 12

2.8 Métodos moleculares para detecção de diversidade genética ...................... 13

3 EFEITO DO MEIO DE CULTURA E DO REGIME DE LUZ NA ESPORULAÇÃO DE Cercospora zeae-maydis ............................................ 16

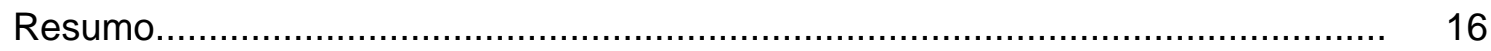

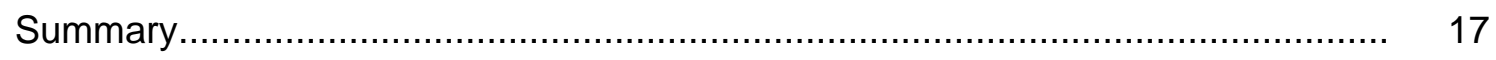

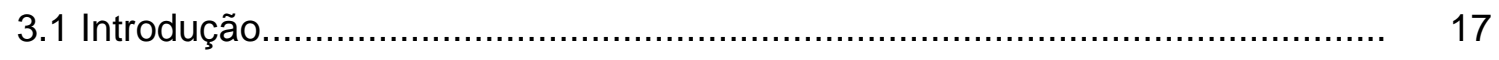

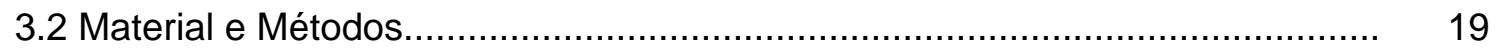

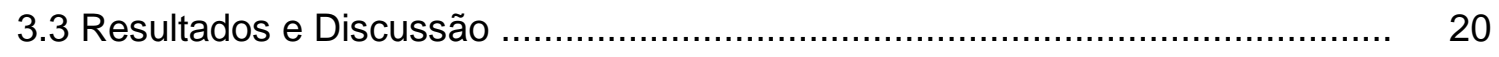

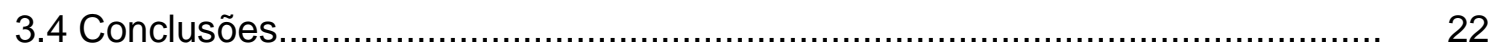

4 REAÇÃO DE LINHAGENS ENDOGÂMICAS DE MILHO A Cercospora zeae-

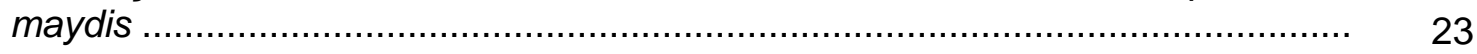

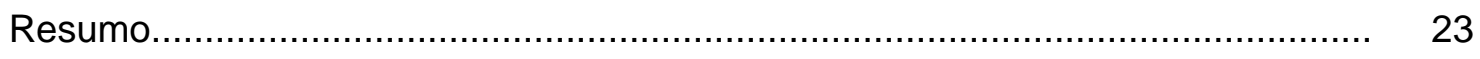

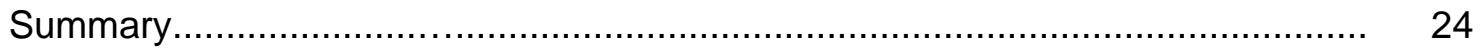




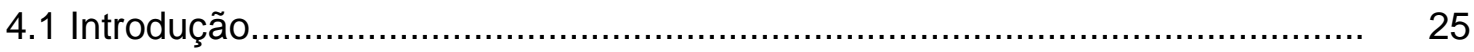

4.2 Material e Métodos.................................................................. 26

4.3 Resultados e Discussão.................................................................... 28

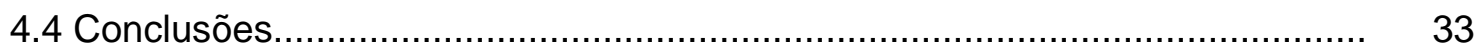

5 CARACTERIZAÇÃO MORFOLÓGICA E MOLECULAR DE ISOLADOS BRASILEIROS DE Cercospora zeae-maydis ................................................... 34

Resumo

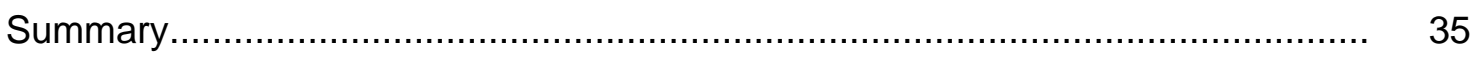

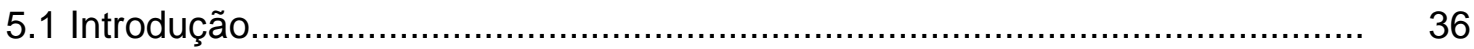

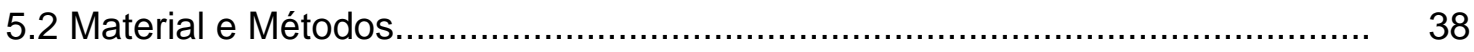

5.2.1 Isolamento e cultivo de C. zeae-maydis ............................................... 38

5.2.2 Isolamento do DNA ........................................................................ 38

5.2.3 Digestão da região ITS-5.8S do rDNA com enzimas de restrição ............... 39

5.2.4 Análise da variabilidade genética através de marcadores AFLP ................. 40

5.2.5 Análise morfométrica de conídios e de produção de cercosporina ............. 41

5.3 Resultados ................................................................................ 42

5.3.1 Análise das regiões ITS e 5.8S do rDNA por RFLP ................................. 42

5.3.2 Análise da variação genética através de marcadores AFLP ...................... 44

5.3.3 Análise morfométrica de conídios e de produção de cercosporina .............. 48

5.3.4 Distribuição geográfica dos grupos de C. zeae-maydis no território

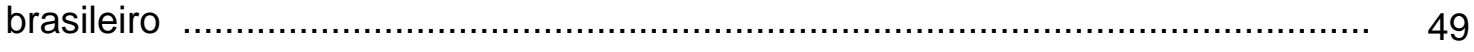

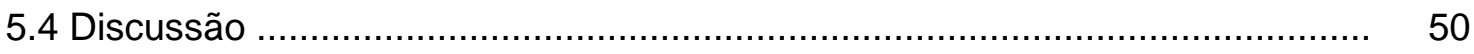

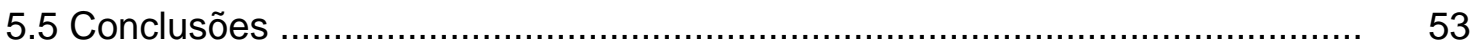

6 ANÁLISES MICROSCÓPICAS DA GERMINAÇÃO, PENETRAÇÃO E CONIDIAÇÃO MICROCÍCLICA DE Cercospora zeae-maydis ............................. 54

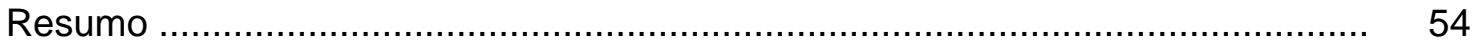

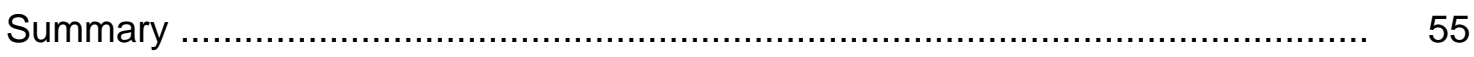

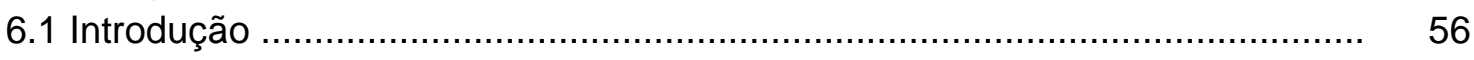

6.2 Material e Métodos ......................................................................... 58

6.2.1 Germinação dos conídios e penetração de C. zeae-maydis em folhas de milho

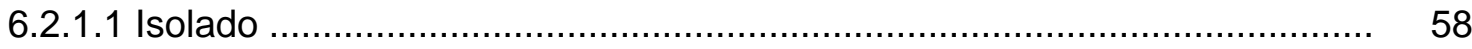

6.2.1.2 Material vegetal ........................................................................ 59

6.2.1.3 Inoculação, coleta das folhas e observação ao microscópio eletrônico de varredura

6.2.2 Conidiação microcíclica em isolados de C. zeae-maydis ........................... 61

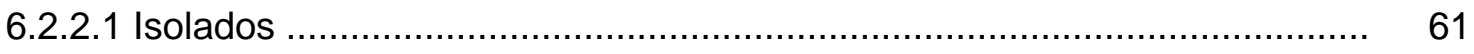

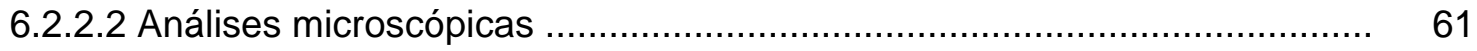

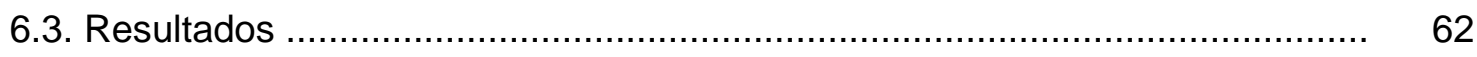

6.3.1 Germinação e penetração de C. zeae-maydis em folhas de milho ............. 62

6.3.2 Conidiação microcíclica em isolados de C. zeae-maydis .......................... 64 


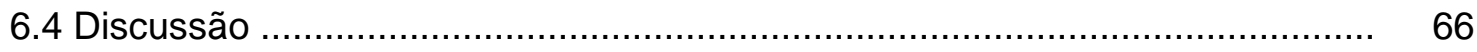

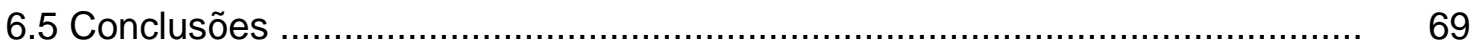

7 AGRESSIVIDADE DE ISOLADOS DE Cercospora zeae-maydis A LINHAGENS DE MILHO ….............................................................. 70

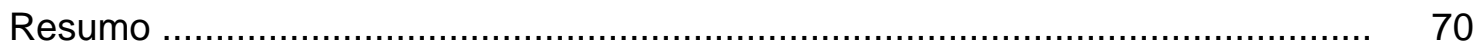

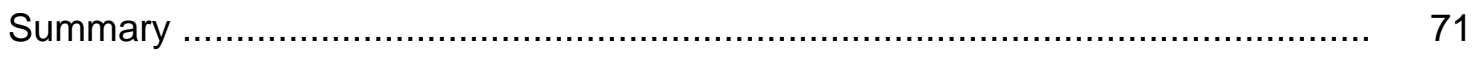

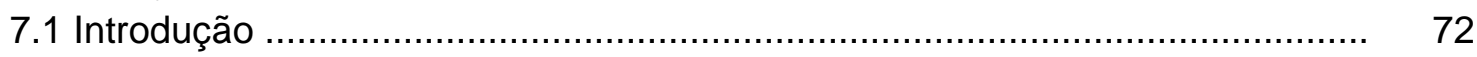

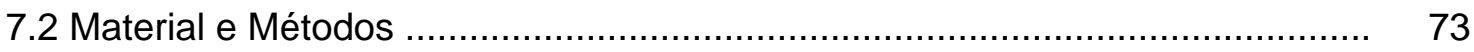

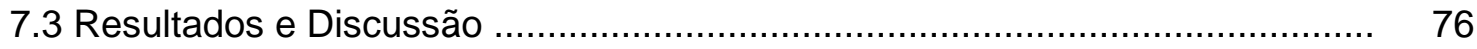

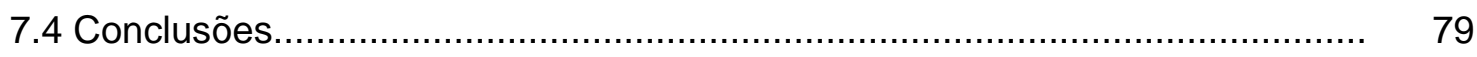

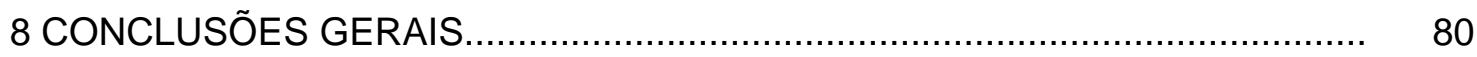

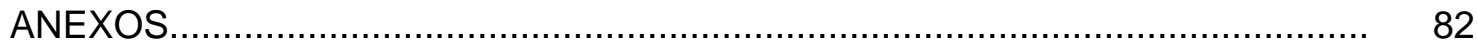

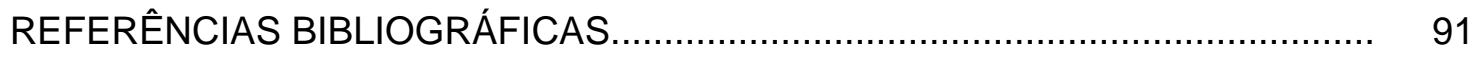




\title{
Cercospora zeae-maydis: ESPORULAÇÃO, DIVERSIDADE MORFO-GENÉTICA E REAÇÃO DE LINHAGENS DE MILHO
}

\author{
Autora: KÁTIA REGIANE BRUNELLI \\ Orientador: Prof. Dr. LUIS EDUARDO ARANHA CAMARGO
}

\section{RESUMO}

A incidência e severidade da mancha de cercospora, causada por Cercospora zeae-maydis Tehon \& Daniels, aumentou significativamente em território brasileiro a partir do ano 2000, sendo hoje considerada uma das principais doenças foliares da cultura do milho. Mesmo assim, poucos estudos com este patossistema foram realizados no Brasil. Este trabalho teve por objetivo determinar meio de cultura e regime luminoso para adequada esporulação de C. zeae-maydis, estudar a reação de um grupo de 118 linhagens endogâmicas de milho quanto a resistência ao patógeno em dois ambientes distintos (Indianópolis-MG e Jardinópolis-SP), observar aspectos microscópicos da esporulação, germinação e penetração em hospedeira 
suscetível e avaliar diferenças morfológicas, genéticas e de agressividade entre isolados coletados na região centro-sul do país. Os resultados indicaram que a melhor esporulação do fungo foi obtida em meio V8 e suco de tomate temperado quando submetidos a fotoperíodo 12/12h (luz/escuro). Quanto a reação das linhagens à doença, foi possível verificar interação diferencial significativa entre genótipo de milho e os dois ambientes, indicando que fatores ambientais ou patogênicos, distintos entre os locais, podem ter contribuído para os discrepantes comportamentos de alguns genótipos. Também foi possível verificar elevado nível de resistência em 12 linhagens em ambos locais, demonstrando a existência de genótipos mais estáveis para resistência com possibilidade de uso em programas de melhoramento da cultura. Através da análise do padrão de restrição gerado pela digestão da região ITS-5.8S do rDNA, de 104 locos AFLP e de mensurações morfométricas dos conídios, foi possível verificar a existência de dois grupos geneticamente distintos de $C$. zeae-maydis em território brasileiro. Estes são relatados na literatura como grupos I e II ou espécies afins (siblings species). Estes grupos foram detectados em todos os locais de coleta do território brasileiro, com exceção de Goiás, onde o grupo I não foi observado. Quanto aos aspectos microscópicos deste patógeno, foi possível verificar que sob condições ambientais adequadas a germinação dos esporos ocorre 13 horas após o contato do esporo com a hospedeira, e a penetração, via estômato, tem início 16 horas após a inoculação. Também foi observado o fenômeno da conidiação microcíclica nos isolados brasileiros. Vinte e seis por cento daqueles pertencentes ao grupo I produziram microconídios, enquanto nenhum do grupo II apresentou esta característica. Deste modo, este é o primeiro relato da existência deste fenômeno no grupo I e ausência no grupo II. Estes estudos demonstram que a população brasileira de $C$. zeae-maydis se assemelha àquelas existentes nos Estados Unidos e na África, com a prevalência dos dois grupos genéticos. 


\title{
Cercospora zeae-maydis: sporulation, morfological- genetic diversity, and reaction in maize lines
}

\author{
Author: KÁTIA REGIANE BRUNELLI \\ Adviser: Prof. Dr. LUIS EDUARDO ARANHA CAMARGO
}

\section{SUMMARY}

The incidence and severity of cercospora leaf spot, caused by Cercospora zeae-maydis Tehon \& Daniels, increased significantly in Brazil in 2000 , being considered today one of the major leaf disease of the crop. Despite this, few researches about the pathosystem come being carried in Brazil. The aims of this work were to identify the suitable culture media and light conditions for sporulation of C. zeae-maydis; to study the reaction of 118 mayze genotypes to pathogen in two different locations (Indianópolis - Minas gerais State and Jardinópolis - São Paulo State); to observe some microscopical aspects of esporulation, germination and penetration in a susceptible maize genotype; and finally to assess morphological and genetic differences among a group of isolates collected in center-south Brazil. The results showed that the better culture media for esporulation was the V8 media and tomato juice, under 12-hours photoperiod. Concerning to genotype reaction to disease, it was possible to verify significant interaction between genotypes and environment, 
indicanting that environmental or pathogenic factors, distinct between locations, may have influenced the reactions of some genotypes. It was possible to identify highly level of resistance in 12 lines in both places, evidencing the existence of stable genotypes that can be used in breeding programs. Analysis of restriction fragments from ITS-5.8S of rDNA, 104 AFLP loci, and conidial measurements, showed the existence of two genetically divergent groups of $C$. zeae-maydis in Brazil. These groups are similar to the ones reported previously reported as I and II groups or siblings species. Both groups were detected in all sampled regions, except Goiás State where no isolates from group I were detected. Concerning to microscopic traits, it was possible to verify that the brazilian isolates of this pathogen have the ability for production of microconidia. Twenty six percent of the isolates of the group I produced microconidia, while none of the group II showed this trait. Thus, this is the first report with presence of MC in the group I but absence in the group II. The results showed that Brazilian isolates are very similar to isolates from USA and Africa, occurring both genetic groups. 


\section{INTRODUÇÃo}

No Brasil, a mancha de cercospora foi relatada pela primeira vez em 1953 (Chupp, 1953) e, durante longo período, foi considerada uma doença secundária, por sua ocorrência esporádica e baixa severidade. Este quadro foi revertido no final da década de 90 , quando foram relatadas severas epidemias em alguns campos de produção nos municípios de Rio Verde e Jataí (GO). Nas safras seguintes, os surtos epidêmicos alastraram-se para toda região centrosul brasileira

O sintoma da doença é caracterizado por lesões alongadas e irregulares que geralmente acompanham o sentido das nervuras. Essas manchas são de coloração cinza, bronze ou marrom, podendo apresentar bordas avermelhadas ou púrpuras. Infecções severas causam a seca e morte das folhas (Chupp \& Sherf, 1960), diminuindo a área fotossintética e, conseqüentemente, a produção.

A etiologia da doença é atribuída a duas espécies fúngicas: Cercospora zeae-maydis e Cercospora sorghi f. sp. maydis. Esta última, embora possa ser encontrada associada a várias lesões características da doença, é descrita como sendo menos agressiva que a primeira (Chupp 1953; Ward et al., 1999). C. zeae maydis tem sido relatada como a responsável por severas epidemias ao redor do mundo (Chupp, 1953; Latterell \& Rossi, 1983; Wang et al., 1998; Fantin et al., 2001), colonizando mais rapidamente o tecido foliar e provocando lesões mais alongadas e em maior número. Estudos com isolados americanos

e africanos de C. zeae-maydis, utilizando marcadores AFLPs e análise da 
região ITS do rDNA, demonstraram a existência de dois grupos geneticamente distintos (Wang et al., 1998; Dunkle \& Levy, 2000). Embora não haja trabalhos sobre a diversidade genética de $C$. zeae-maydis no Brasil, relatos sugerem diferenças de agressividade entre isolados provenientes de diferentes regiões produtoras, indicando, provavelmente, diversidade na população do fungo.

Diversos marcadores moleculares podem ser utilizados para avaliar a diversidade genética de fungos. Dentre estes estão os baseados na amplificação de polimorfismos de comprimento via reação em cadeia da polimerase (AFLP) e na análise, via digestão com enzimas de restrição, da região ITS do rDNA. Neste sentido, o objetivo geral deste trabalho foi a caracterização genética e morfológica de isolados de $C$. zeae-maydis coletados em diversos pontos das regiões Sul, Sudeste e Centro-Oeste do Brasil. Os objetivos específicos foram: i) determinar meio de cultura e regime luminoso que promovam adequada esporulação do fungo em condições controladas (capítulo 3); ii) avaliar um grupo de 118 linhagens quanto a resistência/suscetibilidade a mancha de cercospora em dois ambientes distintos (capítulo 4); iii) analisar, através da região ITS do rDNA, de marcadores AFLP e de estudos morfológicos a diversidade genética de um grupo de 69 isolados coletados na região centro-sul brasileira (capítulo 5); iv) estudar características microscópicas da germinação e penetração do fungo utilizando microscopia eletrônica de varredura (capítulo 6) e v) verificar a agressividades de isolados representantes dos grupos genéticos de C. zeae-maydis em linhagens de milho (capítulo 7). 


\section{REVISÃO DE LITERATURA}

\subsection{A cultura do milho no Brasil}

O agronegócio brasileiro correspondeu a cerca de um terço do PIB nacional no ano de 2003, quando movimentou mais de 420 bilhões de dólares (http:Ilwwww.cna.org.br). Dentro deste mercado, o milho destaca-se como um dos principais produtos agrícolas. A companhia Nacional de Abastecimento (Conab - http:Ilwww.conab.gov.br) estimou a produção da safra 2002/2003 em cerca de 47 milhões de toneladas, um volume $30 \%$ superior à safra passada. Este montante mantém o Brasil na terceira colocação entre os maiores produtores do cereal, ficando atrás apenas dos EUA e da China (Fonte: FAO url: http://apps.fao.org). A grande produção alcançada pelo Brasil nestes últimos anos deve-se, principalmente, ao incremento em área do plantio de segunda época (safrinha), cujo aumento na safra $2002 / 2003$ foi de $13,9 \%$, ou 400 mil ha (Santos et al., 2003), e pela adoção de híbridos mais produtivos e adaptados.

Atualmente, a importância econômica das doenças na cultura do milho é extremamente relevante. Isso se deve a um aumento na incidência e severidade das mesmas, o que tem comprometido o desempenho dos híbridos. Vários fatores têm contribuído para o aumento das doenças no campo, entre eles o aumento de inóculo proporcionado pela prática do plantio direto, pela sucessão de cultivos e pela manutenção da umidade por irrigações via pivô central (Silva, 1997). Assim, a identificação e introdução de genes de 
resistência em programas de melhoramento constitui medida fundamental para garantir híbridos competitivos comercialmente.

Muitas doenças foliares como o complexo das ferrugens (Puccinia polysora, P. sorghi e Physopella zeae), a mancha de Phaeosphaeria (Phaeosphaeria maydis) e, mais recentemente, a mancha de cercospora (Cercospora zeae-maydis, C. sorghi f. sp. maydis), são exemplos de patógenos capazes de comprometer a produtividade de híbridos.

\subsection{Importância da mancha de cercospora e sintomatologia}

A mancha de cercospora, ou cercosporiose, foi relatada pela primeira vez em 1924 por Tehon \& Daniels em espécimes coletadas ao sul de Illinois, nos EUA (Ward et al., 1999). No Brasil, o primeiro relato foi realizado por Chupp (1953) em sua monografia sobre espécies do gênero Cercospora. Nos últimos anos, sua incidência aumentou em várias partes do mundo, incluindo os maiores produtores mundiais como USA, África, Brasil e México (Latterel \& Rossi, 1983; Ward \& Novell, 1998; Ward et al., 1999, Fantin et al., 2001). A redução na produção de grãos em híbridos suscetíveis pode ser considerável. Donahue et al. (1991) estimaram perdas de até 25\% em regiões endêmicas dos EUA. Em agosto de 1995, o Wall Street Journal reportou que a doença reduziu a produção em 50\% em muitos campos de produção de milho dos EUA (Ward et al., 1999). Na Africa do Sul, foram constatadas perdas de $65 \%$ em híbridos suscetíveis (Ward \& Novell, 1998). Essa redução se dá pelo severo ataque do patógeno às folhas, diminuindo a área fotossintetizante. Os danos também ocorrem pelo enfraquecimento da planta, que por sua vez favorece podridões de colmo levando ao tombamento da mesma. No Brasil, dados acerca dos danos causados pelo patógeno são incipientes, mas teme-se que eles possam atingir patamares idênticos aos alcançados em outros países. Os danos, no entanto, não se restringem somente à redução causada diretamente pelo patógeno. Nas safras de 2000 e 2001, vários híbridos altamente produtivos 
tiveram de ser substituídos por outros com menor rendimento mas que apresentavam boa resistência, diminuindo a produtividade.

Os primeiros sintomas da mancha de cercospora são observados geralmente na fase de floração, principalmente nas folhas baixeiras (Lipps, 1987; Ward et al., 1999), onde o patógeno coloniza o limbo foliar, provocando extensas áreas necróticas. O sintoma típico da doença se caracteriza pelo aspecto linear-retangular das lesões que geralmente são delimitadas pelas nervuras (Latterel \& Rossi,1983). Estas manchas possuem coloração palha a verde-oliva e, sob condições de alta umidade relativa, tornam-se cobertas por esporos, conferindo-as uma coloração acinzentada (Chupp, 1953). Por esta característica, esta mancha é conhecida na língua inglesa como mancha foliar cinzenta (gray leaf spot).

Alguns híbridos menos suscetíveis podem apresentar sintomas mais atenuados que os relacionados acima. As manchas, neste caso, podem ser menores e menos retangulares, geralmente acompanhadas por bordos cloróticos ou avermelhados (Freppon et al., 1994). A esporulação neste tipo de lesão é diminuta, o que contribui para uma menor intensidade da epidemia.

\subsection{Etiologia e condições predisponentes}

A etiologia da doença é associada a duas espécies fúngicas: Cercospora zeae-maydis Tehon \& Daniels e Cercospora sorghi Ellis \& Everh $\mathrm{f}$. sp. maydis Ellis \& Everh (Chupp, 1953). Ambas têm sido relatadas em praticamente todas as regiões brasileiras onde o milho é cultivado (Fantin et al.; 2001). Observações em campo, no entanto, demonstram que $C$. sorghi f. sp. maydis é um patógeno pouco eficiente na colonização dos tecidos foliares, uma vez que as lesões produzidas por esta espécie são pequenas, sempre circundadas por halos cloróticos e com presença de pequena quantidade de esporos. A outra espécie, C. zeae-maydis, coloniza de forma mais eficiente a hospedeira, produzindo lesões retangulares, geralmente sem halo clorótico e 
com grande quantidade de conídios, sendo atribuída a esta espécie os recentes surtos epidêmicos da doença (Chupp, 1953; Latterell \& Rossi, 1983; Ward et al., 1999).

A diferenciação das duas espécies baseia-se na morfologia de seus conídios. C. zeae-maydis possui conídios mais curtos e largos, com dimensões variando de $40-165 \mu \mathrm{m}$ de comprimento por $4-9 \mu \mathrm{m}$ de largura, enquanto que em C. sorghi f. sp.maydis estes são mais estreitos, medindo $40-120 \mu \mathrm{m}$ de comprimento por $3-4,5 \mu \mathrm{m}$ de largura (Shurtleff, 1980; Dunkle \& Carson, 1998). Em ambas as espécies, os conídios são hialinos e produzidos em conidióforos pigmentados. Além destas características conidiais, o arranjo dos conidióforos também difere entre as espécies. A primeira possui estas células agregadas em fascículos (5 a 10 conidióforos) que emergem de cavidades do tecido epidermal, formando esporodóquios. Na segunda, esses agregados são menos evidentes, estando os conidióforos muitas vezes isolados uns dos outros, não caracterizando esporodóquios típicos (Fantin et al., 2001).

Cercospora zeae-maydis é um fungo mitospórico segundo a nona edição do dicionário dos fungos (http:Ilwww.indexfungorum.org), sendo sua fase perfeita atribuída ao ascomiceto Mycosphaerella. Embora algumas estruturas típicas deste gênero sejam encontradas em cultivos artificiais (Latterell \& Rossi, 1983), ainda não foi relatada a ocorrência do estádio sexual em lesões, sendo deste modo incerta a existência da fase teleomórfica (Dunkle \& Carson, 1998).

As temperaturas ótimas para o desenvolvimento da mancha de cercospora ocorrem entre 22 e $30^{\circ} \mathrm{C}$ (Shurtleff, 1980). Estudos realizados por Beckman \& Payne (1983) e Ringer \& Grybauskas (1995) indicam que longos períodos de umidade relativa do ar próxima a 100\%, mas na ausência de água livre sobre a folha, são importantes para o início da infecção. Mesmo sob condições favoráveis, o período latente de C. zeae-maydis é longo em comparação a outros patógenos foliares e pode variar de 14 a 28 dias (Ward et al., 1999). Há um consenso que esta espécie de Cercospora é um patógeno que infecta somente o milho (Shurtleff, 1980; Ward et al., 1999). C. zeae-maydis 
é considerado um fraco competidor frente a outros patógenos de solo, sendo sua sobrevivência garantida pela colonização do hospedeiro vivo ou dos restos de cultura presentes na superfície do solo (Latterell \& Rossi, 1983). No Brasil, as práticas da semeadura direta e do plantio de segunda época (safrinha), associadas ao uso de irrigação (pivô central), garantem o incremento e a manutenção do inóculo além da umidade adequada à infecção pelo patógeno, fatos que podem ter contribuído para o aumento da doença nos últimos anos (Fantin et al., 2001).

A disseminação ocorre através dos esporos produzidos pelo fungo na hospedeira ou no tecido estromático formado em restos culturais, os quais são levados pelo vento e/ou chuva para plantas dentro da mesma cultura ou para regiões afastadas do ponto inicial da epidemia (Latterell \& Rossi, 1983; Ringer \& Grybauskas, 1995; Ward et al., 1999). Restos culturais infestados compreendem a mais importante fonte de inóculo dentro de um campo (Latterell \& Rossi, 1983).

\subsection{Diversidade genética e morfológica de C. zeae-maydis - Os grupos genéticos I e II}

A taxonomia no gênero Cercospora é baseada na morfologia de conídios e conidióforos. Chupp (1953), em sua monografia sobre esse gênero, discorreu sobre a confiabilidade de utilizar as características dos conídios e conidióforos na distinção das espécies. De fato, essas características são as utilizadas para distinguir C. zeae-maydis de Cercospora sorghi (Latterell \& Rossi, 1983). As características do conidióforo são, em geral, menos confiáveis que as do conídio, isso porque as primeiras são mais influenciadas pela temperatura e umidade (Wang et al., 1998). Vários trabalhos identificaram diferenças na morfologia dos conídos e conidióforos entre isolados de $C$. zeaemaydis (Tehon, 1925; Chupp 1953; Latterell \& Rossi, 1983), mas estas não foram suficientes para separar os isolados em espécies. 
Quanto à diversidade genética, Carson et al. (1997), através de estudos com marcadores RAPD e rDNA RFLP, separaram isolados de $C$. zeae-maydis em três grupos. Além das diferenças genéticas obtidas por meio dos marcadores, os autores também observaram divergências bioquímicas entre os agrupamentos. Isolados pertencentes a um dos grupos produziram abundante quantidade do pigmento cercosporina em meio de cultura BDA, sendo que isolados dos outros dois grupos o fizeram em pequenas quantidades. Os grupos de Carson et al. (1997) foram confirmados pelas pesquisas de Wang et al. (1998) e Dunkle \& Levy (2000). Wang et al. (1998), utilizando caracterização molecular através da análise de 111 locos AFLP e seqüenciamento das regiões ITS e 5.8S do rDNA, classificaram mais de 100 isolados de C. zeae-maydis, provindos de diversas regiões produtoras de milho dos EUA, em dois grupos distintos. Utilizaram para comparações genéticas isolados de outras duas espécies de Cercospora: $C$. sorghi e C. kikuchii. O seqüenciamento da região ITS demostrou que os isolados do grupo I foram geneticamente mais próximos do isolado de $C$. sorghi (patógeno de sorgo), enquanto os isolados do grupo II se aproximaram de C. kikuchii (patógeno de soja). Esses autores classificaram os isolados somente como grupos e não como espécies, porque não observaram diferenças significativas em virulência e agressividade entre os dois grupos. Essa ausência de interação diferencial pode estar associada à baixa diversidade do patógeno nos EUA ou à utilização de genótipos de milho sem diferenças genéticas para resistência a este patógeno. Dunkle \& Levi (2000), estudando isolados africanos, encontraram evidências de que a população africana se aproxima geneticamente dos isolados do grupo II descritos por Wang et al. (1998), o que pode indicar que isolados deste grupo foram introduzidos nos EUA via importação de sementes da África. No Brasil, não existem trabalhos sobre a composição genética da população de C. zeaemaydis, nem sobre a existência de diferenças de agressividade e/ou virulência entre os isolados oriundos de diferentes regiões produtoras de milho. No 
entanto, tem-se observado que híbridos resistentes em uma região têm comportamento de suscetibilidade em outra.

\subsection{Produção de cercosporina}

Muitas espécies de Cercospora produzem uma fitotoxina não específica chamada cercosporina. Quando estes fungos são cultivados em meio de cultura e sob regime de alta luminosidade, há liberação da toxina no meio na forma de um pigmento de coloração vermelho-púrpura que pode ser facilmente observado. No tecido foliar, reações químicas ocorridas após a liberação desta substância a convertem em produtos capazes de danificar a integridade da membrana celular, desarranjar a estrutura citoplasmática e ocasionar a morte da célula (Fajola, 1978; Daub, 1982; Daub \& Ehrenshaft, 2000). Vários trabalhos sugerem que esta toxina age como um fator de virulência em doenças causadas por espécies de Cercospora (Callahan et al., 1999). Para algumas espécies produtoras de cercosporina, sugere-se que alta intensidade luminosa e produção da toxina são necessários para causar doença (Ehrenshaft et al, 1998; Daub \& Ehrenshaft, 2000; Upchurch et al., 1991), funcionado assim como um fator de patogenicidade.

Os efeitos fisiológicos da cercosporina em plantas hospedeiras são bem conhecidos, mas os mecanismos de biossíntese e as rotas de ação desta toxina na planta durante o estabelecimento da doença são muito pouco caracterizados (Daub \& Ehrenshaft, 2000). Ehrenshalft et al. (1998) e Callahan et al. (1999) isolaram dois genes potencialmente ligados à rota de síntese da cercosporina em C. nicotianae e C. kikuchii, respectivamente. Estudos mais avançados, porém, demostraram que o primeiro, descrito inicialmente como sor1 e posteriormente reclassificado como $p d x 1$, foi expresso também em isolados não produtores de cercosporina. O outro gene, o gfp, foi caracterizado como responsável pela expressão de uma proteína transportadora que facilita a 
liberação e exportação da toxina pela célula fúngica. Deste modo, nenhum dos dois genes estão diretamente ligados a síntese de cercosporina.

No caso de C. zeae-maydis, a falta do estádio sexual dificulta as análises genéticas, uma vez que estudos de segregação dos genes fica comprometido. Shim \& Dunkle (2002), utilizando uma biblioteca de subtração de genes de $C$. zeae-maydis, identificaram oito genes putativamente envolvidos na produção de cercosporina. Estes genes foram expressos apenas em meios indutores da toxina, indicando a provável ligação com sua produção. Comparações das seqüências destes genes mostraram alta identidade com genes envolvidos na síntese de ácidos graxos, de produtos do metabolismo secundário e de proteínas de transporte. As proteínas codificadas por estes genes podem não ter funções enzimáticas diretas na biossíntese de cercosporina, mas elas podem servir como indicadoras da expressão do(s) gene(s) envolvidos na produção da toxina.

Isolados do grupo I de C. zeae-maydis produzem consideravelmente mais cercosporina em meio de cultura que aqueles do grupo II. Esta diferença pode estar associada a baixa capacidade intrínseca dos patógenos do grupo II em produzi-la ou à necessidade de diferentes condições ambientais para a expressão dos seus genes (Jenns et al., 1989; Steinkamp et al., 1981). Trabalhos de quantificação in vivo desta toxina nos grupos I e II de C. zeaemaydis inexistem.

\subsection{O fenômeno da conidiação microcíclica}

O fenômeno da conidiação microcíclica é caracterizado pela formação de esporos secundários a partir da germinação de um conídio, sem fase vegetativa intermediária (Hanlin, 1994). Este processo de reprodução assexual foi descrito em mais de 100 espécies fúngicas (Hanlin, 1994), incluindo patógenos de plantas como Cercospora beticola (Rathaiah, 1977), C. kikuchii (Fernandez et al., 1991) e Claviceps sorghi (Bandyopadhyay et al., 1990). Este 
fenômeno é induzido geralmente por estresse ambiental, como temperaturas elevadas, ou por limitações nutricionais (Rossier et al., 1977; Stavely \& Nimmo, 1968). Anderson \& Smith (1971) observaram o fenômeno em Aspergillus niger depois de submeter os conídios a estresse por calor. Cortat \& Turian (1974) e Rossier et al. (1977) observaram a formação da conidiação secundária em Neurospora crassa depois de expor os conídios a constante agitação em meio líquido e pobre em nutrientes. Em C. zeae-maydis, este fenômeno foi relatado pela primeira vez por Lapaire \& Dunkle (2003). Estes autores verificaram a produção de esporos secundários aos quatro dias após os mesmos terem sido expostos a condições de estresse nutricional. A germinação dos mesmos ocorreu adequadamente até a quarta geração de microconídios, sendo reduzida significativamente a partir deste ponto. Deste modo, flutuações ambientais ou nutricionais ocorridas durante uma quinzena não implicarão em redução do potencial de inóculo e a epidemia poderá ser retomada se tais condições voltarem a ser ideais. Assim, este fenômeno é importante na sobrevivência do patógeno nas áreas de cultivo.

Apesar da importância na sobrevivência do patógeno, a produção de conídios secundários só terá importância epidemiológica se for acompanhada de mecanismos de liberação e dispersão eficientes. De fato, os conídios de espécies de Cercospora são formados em conidióforos eretos na superfície foliar e são facilmente dispersos pelo vento (Latterell \& Rossi, 1983). Assim, pequenas turbulências de ar podem destacar os conídios secundários de seus conidióforos e dispersá-los para ambientes ou hospedeiros mais favoráveis a infecção (Meredith, 1973), contribuindo sobremaneira para a manutenção do inóculo na área. 


\subsection{Controle da doença}

A resistência genética é a medida mais efetiva de controle da mancha de cercospora em milho. Estudos de herança indicam que a resistência é governada por um grande número de genes de pequeno efeito com prevalência de efeitos aditivos (Thompson et al., 1987; de Nazareno et al., 1992; Donahue et al., 1991; Bubeck et al., 1993; Coates \& White, 1994; Marrof et al., 1996). Em adição a isso, um gene conferindo resistência qualitativa e com prevalente ação dominante foi descrito em genótipos cultivados na África do Sul (Gevers et al., 1994). A resistência a doença, principalmente a quantitativa, atua sobre os componentes policíclicos da doença, como período latente e esporulação (Coates \& White, 1994; Freppon et al., 1994). Esses efeitos diminuem a produção de inóculo secundário, reduzindo sobremaneira a epidemia na área. Genótipos que apresentam apenas lesões cloróticas não esporulantes, uma forma de resistência geralmente controlada por interações alélicas dominantes, diminuem a taxa de progresso da doença, proporcionando efetivo controle da doença (Freppon et al., 1994; Freppon et al., 1996).

Em campos de produção, freqüentemente observa-se significativa interação entre genótipo x ambiente (híbrido x local) (Bair \& Ayres, 1986; Bubeck et al., 1993; Carson et al., 1997; Carson et al., 2002). A variação na severidade pode ser devido a instabilidade dos locos de resistência na interação com o ambiente e/ou a diferenças na população do patógeno entre os ambientes (Ward et al., 1999). Deste modo, as causas destas interações devem ser investigadas para proporcionar um controle mais efetivo da doença.

O uso de fungicidas no combate a cercosporiose pode se dar em campos de híbridos suscetíveis onde ocorrem condições ótimas ao desenvolvimento da doença (Ward et al., 1999). No Brasil, durante os surtos epidêmicos de 2000 e 2001, muitos produtores da região Centro-Oeste do país optaram pela aplicação de fungicida. Embora haja comprovada eficiência, a adoção desta prática não se justifica em campos comerciais do cereal, já que o 
preço da aplicação muitas vezes supera a expectativa de lucro dos produtores. Assim, mesmo havendo produtos químicos eficientes no controle da doença, como os benzimidazoles, os triazoles (Munkvold et al., 2001) e as estrobirulinas (Ward et al., 1997), a adoção desta prática só é justificada em campos com alto valor comercial, como campos de produção de sementes ou de milhos especiais (milho doce, pipoca, etc).

\subsection{Métodos moleculares para detecção de diversidade genética}

Marcadores moleculares são importantes ferramentas que podem ser usadas na caracterização genética de populações de fitopatógenos. Marcas moleculares podem ser usadas para avaliar os níveis de diversidade genética e relações filogenéticas entre e dentro de determinada espécie, sendo uma ferramenta auxiliar na determinação de raças ou patótipos (Majer et al., 1996). Alguns tipos de marcadores utilizados com esta finalidade, como aqueles baseados em isoenzimas, são fáceis de serem manipulados mas possuem baixo polimorfismo entre os fungos fitopatogênicos (Burdon \& Roelfs, 1985; Tooley et al., 1985). Marcadores fundamentados em diferenças na molécula de DNA são mais eficientes na detecção de diversidade genética. Mais recentemente, a técnica baseada na amplificação de polimorfismo de comprimento via reação em cadeia da polimerase (AFLP - Amplified fragment length polymorphisms) vem sendo utilizada para estudos desta natureza em diversos organismos (Müeller \& Wolfenbarger, 1999), entre eles os fungos fitopatogênicos (Majer et al., 1998; Wang et al., 1998; Dunkle \& Levy, 2000; Borie et al., 2002; Tooley et al., 2002; Saleh et al., 2003). Esta técnica combina a especificidade, a resolução e o poder de amostragem genômica das enzimas de restrição com a rapidez e praticidade da detecção de polimorfismos da PCR (Ferreira \& Grattapaglia, 1995). 
Nesta tecnologia, o DNA genômico é digerido simultaneamente com duas enzimas de restrição, sendo preferencialmente uma de corte raro e outra de corte freqüente. Posteriormente, adaptadores específicos com seqüências conhecidas são ligados às extremidades coesivas dos fragmentos produzidos pela digestão. As seqüências dos adaptadores são utilizadas como moldes para construção de iniciadores seletivos que serão utilizados para as amplificações. Numa primeira PCR, os iniciadores são sintetizados com a adição de uma base seletiva ao final da seqüência dos adaptadores. Numa segunda amplificação, duas, três ou quatro bases são adicionadas à seqüência original (Majer et al., 1996). Deste modo, o número de fragmentos é reduzido, sendo possível a separação e visualização dos mesmos em matriz de poliacrilamida de alta resolução. Resultados relatados na literatura permitem afirmar que os AFLPs são os mais eficientes entre os marcadores moleculares devido a capacidade de revelar um grande número de fragmentos numa única reação de PCR, superior em dez vezes o número de fragmentos obtidos por outros métodos moleculares (Pejic et al.; 1998).

Outra ferramenta utilizada para estudos filogenéticos é a análise da região espaçadora transcrita do DNA ribossomal (rDNA). A unidade do DNA ribossomal de organismos eucariotos é formada pelo arranjo em tandem de três regiões gênicas (18S, 5.8S e 28S) e duas não gênicas (ITS e IGS). O rDNA é considerado uma região conservada do genoma dos organismos, com poucas mutações ocorridas durante a evolução das espécies (Hillis \& Dixon, 1991; Apel \& Gordon, 1995). Exatamente por apresentar esta característica, o rDNA é atrativo para ser utilizado como marcador em estudos de sistemática (Miller et al., 1999). A região ITS apresenta relativamente maiores taxas de mutação quando comparada as outras regiões do rDNA. Assim, ela é indicada para investigação de diversidade entre populações de uma mesma espécie (Samuels \& Seifert, 1995).

A análise da região ITS pode ser feita através da sua amplificação e seqüenciamento ou pela digestão da mesma com enzimas de restrição, 
produzindo padrões RFLPs. Para a amplificação, são utilizados iniciadores específicos cujos moldes são seqüências finalizadoras e altamente conservadas das sub-unidades $18 S$ e $28 S$ do rDNA. Deste modo, toda a região espaçadora mais a pequena sub-unidade $5.8 \mathrm{~S}$ é amplificada e pode então ser analisada.

Vários trabalhos foram conduzidos utilizando seqüenciamento ou análises de marcas RFLP da região ITS (Wang et al., 1998; Miller et al., 1999; Dunkle \& Levy, 2000; Nielsen et al., 2001; Somai et al., 2002), demonstrando diferenças genéticas importantes em genótipos morfologicamente indistintos. Relações filogenéticas em isolados de Fusarium solani, por exemplo, investigadas pelo seqüenciamento da região ITS, sugeriram a existência de espécies distintas classificadas dentro deste complexo (O'Donnell \& Gray, 1995). Para C. zeae-maydis, Wang et al. (1998), analisando padrões RFLPs das regiões ITS e 5.8S digeridas por duas enzimas de restrição (Taql e Msel), confirmaram a diversidade genética de isolados americanos do fungo, anteriormente detectada por marcas AFLPs, demonstrando a divisão dos isolados em dois grupos geneticamente distintos. Deste modo, este tipo de marca molecular também é promissor em detectar diferenças genéticas em populações fitopatogênicas. 


\section{EFEITO DO MEIO DE CULTURA E DO REGIME DE LUZ NA ESPORULAÇÃO DE Cercospora zeae-maydis}

\section{Resumo}

Algumas espécies fúngicas não esporulam satisfatoriamente em meio de cultura, a exemplo de Cercospora zeae-maydis, agente causal da cercosporiose do milho. A esporulação deste patógeno foi avaliada em sete meios de cultura (V8, suco de tomate temperado, água de coco, aveia, BDA, extrato de folha de milho e extrato de folha de milho $+\mathrm{CaCO}_{3}$ ) e dois regimes luminosos (fotoperíodo de 12 horas e seqüencial -6 dias claro/3 dias escuro). $O$ ensaio foi conduzido em esquema fatorial $7 \times 2$, com os tratamentos dispostos em delineamento inteiramente casualizado com cinco repetições. A parcela experimental compreendeu uma placa de Petri Pyrex® contendo $20 \mathrm{~mL}$ de meio de cultura inoculada com $200 \mu \mathrm{L}$ de uma suspensão de $8 \times 10^{4}$ esporos $/ \mathrm{mL}$. As culturas foram posteriormente incubadas a $27^{\circ} \mathrm{C}$ durante nove dias. Os meios V8 e suco de tomate temperado (STT) sob regime de fotoperíodo $12 \mathrm{~h} / 12 \mathrm{~h}$, foram aqueles que apresentaram melhor indução de esporulação, resultando na produção de $22,4 \times 10^{4}$ conídios/ mL e 28,62 x 10 conídios/mL, respectivamente. 


\section{Effect of culture media and light exposure on the sporulation of Cercospora zeae-maydis.}

\section{Summary}

Some fungal species, like Cercospora zeae-maydis, causal agent of maize gray leaf spot, do not satisfactorily produce spores in artificial media. The conidial production of Cercospora zeae maydis was evaluated on seven culture media (V8, tomato juice, coconut water, oat, PDA, maize leaf extract and maize leaf extract plus $\mathrm{CaCO}_{3}$ ) under two light exposure regimens (12-hours photoperiod or six days under continuous light followed by three days of continuous darkness). The experiment was arranged as a $7 \times 2$ factorial design in a completely randomized design with five replicates. A single Pyrex ${ }^{\circledR}$ Petri dish containing $20 \mathrm{~mL}$ of culture media inoculated with $200 \mu \mathrm{L}$ of conidial suspension $\left(8 \times 10^{4}\right.$ conidia/mL) comprised the experimental unit. Plates were incubated at $27^{\circ} \mathrm{C}$ for nine days. The highest conidial production was obtained on V8 and tomato juice media under 12-hours photoperiod, resulting in the production of 22.4 and $28.62 \times 10^{4}$ conidia/mL respectively.

\subsection{Introdução}

Cercospora zeae-maydis Tehon \& Daniels é um importante patógeno da cultura do milho, causando a doença foliar conhecida como mancha de cercospora ou cercosporiose. Sob condições ambientais adequadas e hospedeiro suscetível, esta doença pode causar perdas de até 65\% na produção (Donahue et al., 1991; Ward \& Novell, 1998; Ward et al., 1999). Essa redução deve-se basicamente à indução precoce de senescência na planta 
causada pelo abundante número de lesões. No Brasil, esta doença causou sérias epidemias nas safras de 2000/2001, quando muitos dos híbridos mostraram-se suscetíveis. Nas safras de 2002/2003, a mancha de cercospora foi controlada, em parte, pelo emprego de híbridos resistentes. Porém, em algumas regiões de Goiás e Minas Gerais, o patógeno ainda causa danos significativos à produção. Como o controle da doença é realizado, prioritariamente, pelo uso de híbridos resistentes, a determinação de condições ótimas para a produção de esporos in vitro é importante para trabalhos que utilizam inoculação artificial para identificar genótipos resistentes ao patógeno.

Espécies do gênero Cercospora caracterizam-se pelo lento crescimento e pela reduzida esporulação em meios de cultura (Nagel, 1934). Agentes físicos são capazes de induzir ou inibir o desenvolvimento vegetativo e reprodutivo da maioria dos fungos, dentre eles os mais importantes são a temperatura e a luminosidade. A temperatura modula a produção de proteínas e enzimas responsáveis pela manutenção da célula fúngica (Griffin, 1994). Estudos envolvendo espécies de Cercospora demonstram que temperaturas entre 25 e $27^{\circ} \mathrm{C}$ são ideais para produção de esporos (Veiga, 1973; Beckman \& Payne, 1983; Queiroz \& Menezes, 1993). A luminosidade exerce efeito direto sobre a célula fúngica, induzindo ou inibindo a formação de estruturas de reprodução, embora haja algumas espécies que são indiferentes à quantidade e/ou qualidade da luz (Hawker, 1957; Coêlho et al., 1997).

Este trabalho teve por objetivo selecionar combinações de meios de cultura e regime luminoso que promovam abundante esporulação de $C$. zeaemaydis. 


\subsection{Material e Métodos}

Os meios de cultura utilizados foram: V8 $(200 \mathrm{~mL}$ de suco de vegetais V8 "Campbell Soup Co."; $16 \mathrm{~g}$ de agar; 3,2 g de $\mathrm{CaCO}_{3}$ e $800 \mathrm{~mL}$ de água destilada), STT (200 mL de suco de tomate temperado "Super Bom"; $16 \mathrm{~g}$ de agar; $3,2 \mathrm{~g}$ de $\mathrm{CaCO}_{3}$ e $800 \mathrm{~mL}$ de água destilada), AV (20 g de farinha de aveia "Otker"; 16 g de ágar e $1000 \mathrm{~mL}$ de água), CO (1000 mL de água de coco "Sokoko" e $16 \mathrm{~g}$ de ágar), FM (extrato de $80 \mathrm{~g}$ de folha de milho picada e levada ao fogo até levantar fervura, $16 \mathrm{~g}$ de ágar e água até completar $1000 \mathrm{~mL}$ ), FM$\mathrm{CaCO}_{3}\left(\mathrm{FM}+3,2 \mathrm{~g}\right.$ de $\left.\mathrm{CaCO}_{3}\right)$ e BDA (extrato de $200 \mathrm{~g}$ de batata, $20 \mathrm{~g}$ de dextrose e $16 \mathrm{~g}$ de ágar e água até completar o volume de $1000 \mathrm{~mL}$ ). Após o preparo, estes meios foram autoclavados a $121^{\circ} \mathrm{C}$ por 20 minutos e vertidos assepticamente em placas de Petri Pyrex®.

O isolado monospórico IN-5 utilizado neste ensaio foi obtido por isolamento direto a partir de folha com sintoma típico da doença coletada em campo de produção no município de Indianópolis (MG). Este isolado foi cultivado em meio V8 durante nove dias, sob fotoperíodo 12h/12h (12 horas de claro seguido de 12 horas de escuro), até a formação de esporos. Duzentos microlitros de uma suspensão de $8 \times 10^{4}$ esporos $/ \mathrm{mL}$ foram depositados em cada placa de Petri. Estas foram incubadas durante nove dias sob um dos regimes de luminosidade: fotoperíodo $12 \mathrm{~h} / 12 \mathrm{~h}$ ou seqüencial com seis dias de claro contínuo seguido por três dias de escuro. As colônias foram incubadas em câmaras de crescimento (Tecnal TE-400) a temperatura de $27^{\circ} \mathrm{C}$.

$O$ ensaio foi conduzido em esquema fatorial $7 \times 2$ (meios de cultura $x$ luminosidade), totalizando 14 tratamentos com cinco repetições, em delineamento inteiramente casualizado. As parcelas consistiram de uma placa de Petri Pyrex® contendo $20 \mathrm{~mL}$ de meio de cultura.

Decorrido o período de incubação, as placas receberam $10 \mathrm{~mL}$ de água destilada contendo $0,01 \%$ de Tween 20 e, com o auxílio de uma lâmina de vidro, as colônias foram delicadamente raspadas para liberação dos conídios. A 
suspensão foi filtrada em camada dupla de gaze para retenção dos fragmentos miceliais e restos de meio de cultura. O número de conídios de cada parcela foi determinado ao microscópio ótico com auxílio de hemacitômetro.

Os dados da contagem conidial de cada parcela foram transformados para $\sqrt{ }(x+1)$ e submetidos a análise de variância. As médias dos tratamentos foram comparadas entre si pelo teste de Tukey em nível de 1\% de significância, com o auxílio do programa estatístico SAS (versão 6.2 - SAS Institute, Cary, $\mathrm{NC})$.

\subsection{Resultados e Discussão}

Houve diferenças significativas entre tratamentos com relação a esporulação de $C$. zeae maydis (Tabela 1). As colônias fúngicas formadas nos meios V8, STT, AV e CO apresentaram grande quantidade de conidióforos, mas apenas os meios V8 e STT induziram abundante formação de esporos, tanto sob fotoperíodo quanto sob regime de luz seqüencial (Tabela 1). O meio BDA estimulou pequena quantidade de conidióforos. Já nos meios FM e FM$\mathrm{CaCO}_{3}$, praticamente não houve formação destas estruturas. Os meios V8 e STT são aqueles que apresentam maior riqueza nutricional e maior quantidade de carbohidratos complexos. Estas características são citadas por diversos autores como capazes de induzir a reprodução de muitos fungos mitospóricos (Lukens 1963; Moore-Landecker, 1972; Strandberg, 1987). O meio V8 é relatado como bom indutor de esporulação em várias espécies do gênero Cercospora (Veiga, 1973; Beckman \& Payne 1983; Queiroz \& Menezes, 1993; Hanada et al., 2002). Também o meio STT, uma variação do meio V8, foi indicado por Queiroz \& Menezes (1993) como capaz de induzir formação de esporos em Cercospora nicotianae. Comparando ambos os meios, STT mostrase mais vantajoso do ponto de vista prático, uma vez que o mesmo é composto por um produto nacional facilmente adquirido no país. 
Tabela 1. Produção de conídios de C. zeae-maydis submetido a sete meios de cultura e dois regimes luminosos

\begin{tabular}{cccc}
\hline & \multicolumn{2}{c}{ Esporulação $\left(10^{4} \text { conídios } / \mathrm{mL}\right)^{1}$} & \\
\cline { 2 - 3 } Meio de cultura & Fotoperíodo & Luz seqüencial & Média \\
\hline STT & 28,62 & 12,36 & $20,50 \mathrm{a}$ \\
V8 & 22,40 & 5,350 & $13,90 \mathrm{a}$ \\
AV & 0,225 & 0,850 & $0,54 \mathrm{~b}$ \\
BDA & 0,550 & 0,125 & $0,34 \mathrm{~b}$ \\
FM-CaCO & 0,275 & 0,025 & $0,15 \mathrm{~b}$ \\
FM & 0,425 & 0,025 & $0,22 \mathrm{~b}$ \\
Média & 0,850 & 0,00 & $0,42 \mathrm{~b}$ \\
\hline Médias de cinco repetições; Médias seguidas de mesma letra minúscula na coluna \\
e maiúscula na linha não diferem entre si pelo teste de Tukey (p=0,01).
\end{tabular}

Neste estudo, a luz não influenciou a morfologia da colônia, crescimento micelial ou o tempo de formação da colônia. Porém, a quantidade de conídios produzidos sob fotoperíodo foi significativamente superior (Tabela 1). A luminosidade pode exercer efeito indutor ou inibidor sobre a formação de estruturas reprodutivas. Trione \& Leach (1969) relataram que, para fungos cuja esporulação é induzida pela luz, este agente físico age diretamente na ativação de enzimas chaves envolvidas na esporogênese. Os mesmos autores afirmam ainda que a quantidade e qualidade da luz necessárias para induzir a formação de estruturas reprodutivas variam de acordo com a espécie fúngica. Beckman \& Paine (1983) já haviam relatado a maior produção de conídios quando 
submeteram um isolado de C. zeae-maydis a fotoperíodo 12/12. Estes verificaram que dez dias de claro contínuo seguido de três dias de escuro induziram a esporulação, embora em quantidade inferior aquela do fotoperíodo. A ausência de luz como fator de indução da esporulação já foi relatada para diversos fungos fitopatogênicos como Alternaria macrospora (Ansari et al.,1989), Alternaria brassicae (Rotem et al., 1989), Alternaria solani (Lukens, 1963), Fusarium solani (Assis et al., 1997) e Mycosphaerella fijensis (Hanada et al., 2002). Neste caso, a luz age como foto-inibidor da esporulação. Assim, o fornecimento de luz seguido por um período de escuro é necessário para a completa reprodução do patógeno. Estudos preliminares (dados não publicados) indicaram que a submissão de colônias de C. zeae-maydis a regime de luz contínua inibiram a formação de esporos, mas não a de conidióforos. Assim, infere-se que esta espécie fúngica necessita de alternância de regime luminoso para completar a reprodução.

Com base no exposto, a melhor condição de incubação visando a produção de conídios de C. zeae-maydis deu-se pela associação do regime de luz 12 horas claro/12 horas escuro e os meios de cultura V8 ou STT.

\subsection{Conclusões}

1. Os meios de cultura V8 e STT (suco de tomate temperado) foram aqueles que melhor promoveram a esporulação de $C$. zeae-maydis, sendo que o STT tem a vantagem de ser um produto nacional e de fácil aquisição.

2. Fotoperíodo $12 / 12 \mathrm{~h}$. (luz/escuro) foi o melhor regime luminoso para esporulação desta espécie fúngica em todos os meios de cultura testados. 


\section{REAÇÃO DE LINHAGENS ENDOGÂMICAS DE MILHO A Cercospora zeae-maydis}

\section{Resumo}

A avaliação dos níveis de resistência de linhagens de milho a patógenos é atividade fundamental de qualquer programa de melhoramento, uma vez que estas são utilizadas para a produção de híbridos comerciais. Este trabalho objetivou avaliar os níveis de resistência de 118 linhagens de milho a mancha de cercospora, causada pelo fungo Cercospora zeae-maydis, além de determinar qual o melhor estádio fenológico para avaliação da doença em campo. Os experimentos foram conduzidos nas estações experimentais da Dow AgroSciences nos municípios de Indianópolis (MG) e Jardinópolis (SP) em delineamento látice 11 × 11 com três repetições. A severidade foi avaliada nos estádios fenológicos cinco (florescimento), sete (milho verde) e oito (milho pamonha) e os dados foram utilizados para o cálculo da área abaixo da curva de progresso da doença (AACPD). As análises de variância individual e conjunta dos ensaios detectaram diferenças entre os genótipos e comportamento diferencial destes em função do ambiente. Doze linhagens foram altamente resistentes em ambos locais, não diferindo estatisticamente do híbrido C-333-B (padrão de resistência), ao passo que sete delas foram estatisticamente iguais ou mais suscetíveis que o padrão de suscetibilidade (DAS-8392), em ambos ambientes. Foi identificada alta correlação entre a 
AACPD e a severidade no estádio fenológico 7, demonstrando a possibilidade da realização de apenas uma avaliação neste estádio, tornado o trabalho de seleção de linhagens superiores mais rápido e eficiente.

\section{Reaction of maize endogamic lines to Cercospora zeae-maydis}

\section{Summary}

The use of genetically resistance maize hybrids is the preferred control strategy of gray leaf spot, caused by Cercospora zeae-maydis. The objectives of this study were to evaluate the levels of resistance of 118 maize lines and also to determine the best phenological stage to assess disease severity. Experiments were conducted at two locations (Jardinópolis-SP and Indianópolis$M G$ ) using an $11 \times 11$ latice experimental design with three replicates. Disease severity was evaluated at the flowering (fenological stage five), midsilk (seventh stage), and milk stage (eight stage). Disease severity data were used to calculate the Area Under Disease Progress Curve (AUDPC). There were significant differences among genotypes and significant genotype $\mathrm{x}$ environment interaction. Twelve lines displayed high levels of resistance in both environments comparable to that of the resistance hybrid control (C-333-B). Seven lines were as susceptible or more susceptible than the suscetible control (DAS-8392). There was a high correlation between AUDPC and the disease severity at the midsilk stage, indicating the possibility of using a single evaluation at this stage. 


\subsection{Introdução}

A mancha de cercospora, causada pelo fungo Cercospora zeae-maydis, é uma das principais doenças da cultura do milho (Zea mays L.) em vários países. No Brasil, o patógeno foi relatado pela primeira vez em 1953 (Chupp, 1953), mas a doença só adquiriu caráter epidêmico a partir de 2000 (Fantin et al., 2001). O impacto da doença na cultura se deve ao fato de o patógeno colonizar grande área do tecido foliar levando à senescência precoce e conseqüente redução da produtividade. Os danos causados pela doença podem ser significativos, ocasionando reduções na produção entre 25 a 65\%, de acordo com as observações realizadas nos EUA e África do Sul (Donahue et al.; 1991; Ward \& Novell, 1998; Ward et al., 1999). No Brasil os dados sobre os danos causados por esta doença são incipientes, mas acredita-se que eles sejam iguais àqueles já relatados naqueles países.

A doença pode ser controlada pelo uso de produtos químicos como propiconazoles e mancozeb (Munkvold et al.; 2001), mas o alto custo das aplicações o torna inviável. Assim, o uso de híbridos resistentes é a medida mais eficiente para seu controle, a exemplo das demais doenças da cultura. Deste modo, a identificação de linhagens com níveis satisfatórios de resistência é fundamental para o sucesso de programas de melhoramento.

Quantificações de doenças podem ser realizadas através de avaliações durante os estádios vegetativos e reprodutivos da planta com o auxílio de escalas diagramáticas. Estas avaliações podem ser utilizadas para o cálculo da área abaixo da curva de progresso da doença (AACPD) (Campbell \& Maden, 1990), que corresponde a integrações numéricas da proporção de doença versus tempo. Este método permite aferições mais estáveis sobre o progresso da doença, já que as flutuações ambientais ocorridas entre as diferentes avaliações são minimizadas com as integrações. Campbell \& Maden (1990) sugerem que a AACPD pode ser usada como um descritor de uma epidemia, resumindo curvas de progresso da doença em dados únicos que podem, 
através de análises estatísticas, subsidiar interpretações da resposta dos genótipos quanto a sua resistência ou suscetibilidade à doença no campo.

Este trabalho teve como objetivos a) avaliar um grupo de 118 linhagens de programas públicos e privados de melhoramento de milho quanto a resistência à mancha de cercospora em dois ambientes distintos (Jardinópolis, SP e Indianópolis, MG) e b) determinar qual a melhor época de avaliação da doença que permita obter informações mais próximas daquelas obtidas com a AACPD.

\subsection{Material e Métodos}

Os experimentos foram conduzidos nas estações experimentais da empresa Dow AgroSciences Ltda. situadas nos municípios de Jardinópolis (SP) e Indianópolis (MG). A área experimental de Jardinópolis está localizada a 20054'58" de latitude Sul, 47053'42"de longitude Oeste e 560m de altitude, enquanto a de Indianópolis está a 18055'31" de latitude Sul, 47051'12" de longitude Oeste e $975 \mathrm{~m}$ de altitude. As semeaduras foram realizadas nos dias 2 (Jardinópolis) e 3 (Indianópolis) de março de 2002. Foram utilizadas 118 linhagens, em avançado grau de endogamia, e três híbridos comerciais com conhecida reação de resistência/suscetibilidade a doença (C-3333-B - alto grau de resistência; Tork - moderada resistência e DAS-8392 - alto grau de suscetibilidade) como controles. As linhagens que compuseram este estudo possuem diferentes genealogias, sendo compostas por germoplasma tropical, subtropical e temperado (Tabela 2; Anexo).

Os experimentos foram conduzidos em delineamento látice $11 \times 11$, com três repetições. Cada parcela foi constituída de uma fileira de três metros de comprimento contendo cinco plantas por metro, com espaçamento entre fileiras de $0,9 \mathrm{~m}$. As áreas experimentais foram circundadas com um híbrido suscetível, semeado 30 dias antes da implantação dos ensaios. A bordadura do 
experimento conduzido em Jardinópolis recebeu três inoculações artificiais com propágulos infectivos do fungo cultivados em sementes de sorgo, sendo estas realizadas 40, 50 e 60 dias após a semeadura da mesma. Estas inoculações foram realizadas com um "pool" de isolados obtidos a partir de folhas contendo lesões esporulantes do fungo coletadas em diversos pontos da própria estação experimental. Em Indianópolis, não houve necessidade de inoculações artificiais na bordadura, uma vez que a região tem histórico de alta incidência da doença. Além disso, a presença de plantas de milho severamente infectadas em áreas adjacentes ao experimento, garantiu a presença de inóculo no experimento. Para manutenção das condições de umidade, foram realizadas irrigações suplementares, sempre que necessário. Os demais tratos culturais foram realizados de acordo com as normas adotadas na empresa, conforme as recomendações técnicas para a cultura.

Para avaliação da doença, adaptou-se uma escala de severidade de planta inteira desenvolvida para a ferrugem causada pelo fungo Puccinia sorghi (Agroceres, 1996). As notas de severidade desta escala variavam de 1 a 9 , onde $1=0 \%$ de doença; $2=1 \%$ de área lesionada, $3=2,5 \%, 4=5 \%, 5=10 \%$, $6=25 \%, 7=50 \%, 8=75 \%$ e 9 mais de $75 \%$ de área lesionada. Em ambos experimentos, as avaliações foram realizadas nos estádios fenológicos cinco (florescimento), sete (milho verde) e oito (milho pamonha) (Fancelli, 1986). Os dados de severidade foram utilizados para o cálculo da AACPD, conforme metodologia descrita por Campbell \& Maden (1990). De posse das medidas da AACPD foram realizadas ANOVAs individuais para cada experimento, seguido do teste Scot-Knott para comparação múltipla de médias. Posteriormente, realizou-se análise de variância conjunta entre os experimentos para determinação do efeito genótipo $x$ ambiente. Também foram obtidas estimativas de correlação classificatória de Pearson, entre as severidades da doença em cada avaliação e as estimativas da AACPD. As análises estatísticas foram realizadas com o auxílio do programa estatístico SAS (versão 6.2 - SAS 
Institute, Cary, NC), enquanto que a comparação de médias, com o programa Genes versão Windows (Cruz, 2001).

\subsection{Resultados e Discussão}

Os níveis de severidade da doença registrados em ambos experimentos foram suficientes para discriminar genótipos com diferentes níveis de resistência (Tabela 3). A análise de variância da AACPD detectou diferenças significativas $(p<0,01)$ entre genótipos para cada experimento (Tabela 3$)$. Com relação a resistência, doze linhagens mostraram-se altamente resistentes em ambos locais (ESALQ3, UFG88, DAS1, ESALQ17, GNS57, GNS68, ESALQ15, GNS64, ESALQ16, GNS55, GNS62, DAS4), não diferindo estatisticamente do híbrido C-333-B, utilizado como padrão de resistência (Figura 1). Estas linhagens parecem conter genes de resistência mais estáveis frente as variações ambientais existentes nestes locais, tornado-as adequadas fontes de resistência aos programas de melhoramento. Quanto as linhagens suscetíveis, sete (ESALQ52, ESALQ53, GNS71, GNS85 UFG104, UFG107, UFG110) demonstraram alta suscetibilidade em ambos locais. A linhagem GNS71 foi a mais suscetível, sendo que em Jardinópolis alcançou maior valor de AACPD $(209,7)$ quando comparado a Indianópolis $(188,4)$. Analisando as bases genéticas destas linhagens (Tabela 2; Anexo), averigua-se que tanto os genótipos suscetíveis quanto aqueles resistentes apresentam grande predomínio de germoplasma tropical. 
Tabela 3. Resumo da análise de variância individual para os ambientes de Jardinópolis e Indianópolis utilizando como medida de severidade a AACPD

\begin{tabular}{lcccccc}
\hline & \multicolumn{3}{c}{ Jardinópolis } & \multicolumn{3}{c}{ Indianópolis } \\
\cline { 2 - 7 } \multicolumn{1}{c}{ F.V. } & G.L. & Q.M. & Pr>F & G.L. & Q.M. & Pr>F \\
\hline Genótipo & 119 & 343258 & 0,0001 & 120 & 323595 & 0,0001 \\
Repetição & 2 & 1453 & 0,196 & 2 & 9294 & 0,0003 \\
Blocos/repetição & 30 & 87552 & 0,0001 & 30 & 51309 & 0,0001 \\
Resíduo & 208 & 91995 & & 209 & 113395 & 0,0001 \\
\hline Total & 359 & & & 361 & & \\
\hline Média & \multicolumn{7}{c}{115,6} & & & 117,6 & \\
CV (\%) & \multicolumn{7}{c}{18,2} & & & & \\
\hline
\end{tabular}



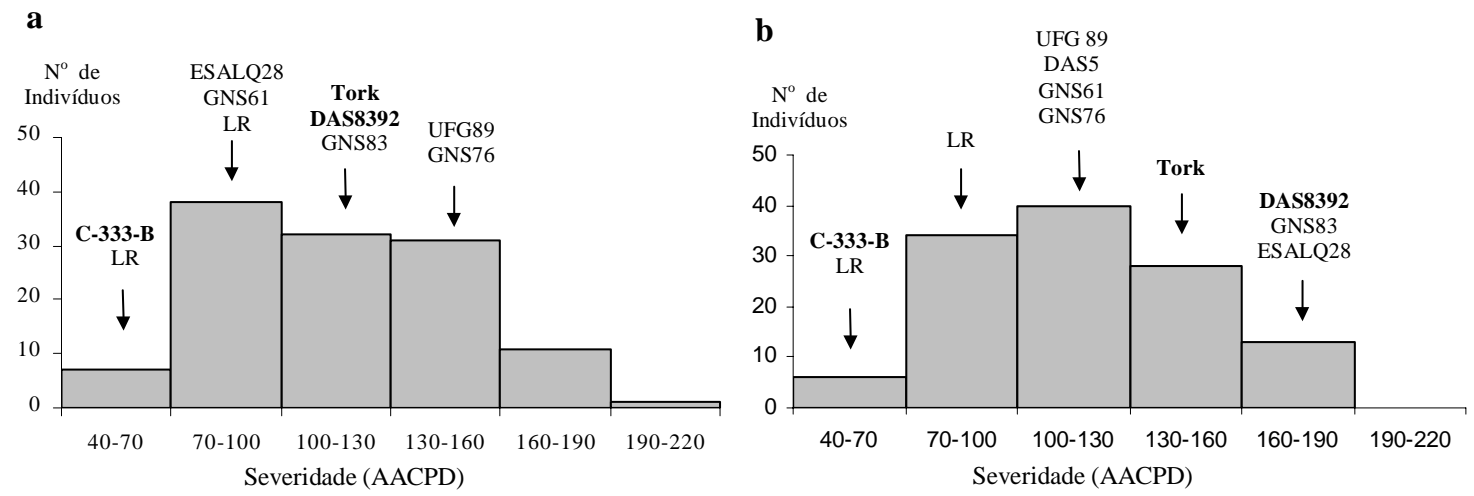

Figura 1 - Distribuição das freqüências para a severidade, medida através da AACPD, em a) Jardinópolis e b) Indianópolis. Em negrito estão os híbridos utilizados como padrões de resistência/suscetibilidade. LR indica a posição das doze linhagens mais resistentes (ESALQ3, UFG88, DAS1, ESALQ17, GNS57, GNS68, ESALQ15, GNS64, ESALQ16, GNS55, GNS62, DAS4). Note que as linhagens indicadas no gráfico são aquelas que apresentaram maiores interações diferenciais nos dois ambientes testados

$\mathrm{Na}$ análise de variância conjunta entre os experimentos, foi possível verificar diferenças significativas $(p<0,01)$ entre genótipos e interação entre genótipo $x$ ambiente (Tabela 4). A interação genótipo $x$ ambiente pode ser explicada por duas hipóteses. Na primeira, o local poderia influenciar a expressão dos genes que regulam a resistência nos genótipos estudados. Interferência do ambiente na expressão de genes é vastamente descrita na literatura. Em milho, Di Rienzo et al. (2002), estudando a resistência da planta ao Mal do Rio Quarto, verificaram baixa estabilidade de alguns genótipos frente à variações ambientais, inferindo que o ambiente e não o patógeno foi o responsável pela instabilidade. Numa segunda hipótese, a presença de populações geneticamente diferentes do patógeno estaria agindo em cada um 
dos locais estudados. Essas diferenças genéticas já foram relatadas no patossitema C. zeae-maydis x milho por vários autores (Carson et al., 1997; Wang et al.,1998; Dunkle \& Levy, 2000; Carson et al., 2002), embora ainda não tenha sido comprovada a existência de raças fisiológicas neste patossistema. Neste trabalho, os genótipos que apresentaram as maiores variações de resistência em função do local foram UFG89, UFG98, GNS61, GNS76, GNS83, ESALQ19, ESALQ28 e DAS5 (Figura 1). Também o híbrido DAS-8392, padrão de suscetibilidade, apresentou interação diferencial entre os locais testados. Em Indianópolis, este genótipo comportou-se como altamente suscetível, não diferindo estatisticamente das linhagens mais suscetíveis do experimento. Já em Jardinópolis, ele comportou-se como intermediário, sendo suplantado em severidade por 22 linhagens.

Tabela 4. Resumo da análise de variância conjunta utilizando como medida de severidade a AACPD

\begin{tabular}{lccc}
\hline \multicolumn{1}{c}{ F.V. } & GL & QM & Pr>F \\
\hline Repetição (Local) & 4 & 2710 & 0,0003 \\
Genótipo & 120 & 4161 & 0,0001 \\
Bloco (Local x Repetição) & 60 & 1004 & 0,0001 \\
Local & 1 & 595 & 0,2724 \\
Genótipo x Local & 119 & 1305 & 0,0001 \\
Resíduo & 417 & 492 & \\
\hline Total & 721 & & \\
\hline Média & & 116,6 & \\
CV (\%) & & 19 & \\
\hline
\end{tabular}


O uso da AACPD permite ao pesquisador obter informações acerca do comportamento dos genótipos durante o período em que a epidemia está ocorrendo no campo. Embora não haja questionamento quanto a eficiência desta medida, o seu uso em programas de melhoramento tem entrave prático, já que a utilização de um grande número de genótipos torna inviável mais de uma avaliação para uma mesma doença. Assim, a utilização de uma única época que seja representativa do comportamento dos genótipos durante uma epidemia no campo é desejada. Na tabela 5 são apresentados os coeficientes de correlação de Pearson entre as notas de severidade da doença nos estádios fenológicos 5 (florescimento), 7 (milho verde) e 8 (milho pamonha) e a AACPD, para ambos ambientes estudados. Todas as correlações foram positivas e significativas ( $P \leq 0,01)$, embora aquelas da primeira avaliação (estádio 5 ) tenham sido de menor magnitude. A alta correlação encontrada entre a severidade da doença no estádio fenológico sete e a AACPD para ambos locais (0,90 em Indianópolis e 0,94 em Jardinópolis) demonstra que uma única avaliação realizada neste estádio fenológico proporciona informações semelhantes as obtidas com a AACPD (Tabela 5). Razoáveis correlações também foram encontradas no estádio fenológico oito, embora numericamente inferior ao estádio anterior, provavelmente porque as plantas já se encontravam em avançada senescência natural, influenciando assim na diminuição dos coeficientes de correlação. Deste modo, uma única avaliação realizada tardiamente, próxima ao estádio de milho verde, pode fornecer informações semelhantes a AACPD, tornando o processo de seleção de genótipos superiores mais rápido, e por conseguinte mais eficiente. 
Tabela 5. Coeficientes de correlação de Pearson entre as notas de severidade da doença em cada época de avaliação a e AACPD

\begin{tabular}{ccc}
\hline \multirow{2}{*}{ Estádio fenológico } & \multicolumn{2}{c}{ AACPD } \\
\cline { 2 - 3 } & Jardinópolis & Indianópolis \\
\hline 5 - florescimento & $0,46^{\star \star}$ & $0,39^{\star \star}$ \\
7 - milho verde & $0,94^{\star \star}$ & $0,90^{\star \star}$ \\
8 - milho pamonha & $0,74^{\star \star}$ & $0,86^{\star \star}$ \\
\hline
\end{tabular}

** Significativamente diferente de zero a $1 \%$ de probabilidade

\subsection{Conclusões}

1. Foi possível identificar linhagens com satisfatórios níves de resistência a C. zeae-maydis.

2. Houve interação diferencial entre genótipo e ambiente, indicando que fatores ambientais ou relativos ao patógeno atuam nestes ambientes.

3. Constatou-se, através dos altos coeficientes de correlação entre a AACPD e a avaliação da severidade da doença no estádio fenológico sete (milho verde), que uma única avaliação neste estádio fornece dados semelhantes aqueles obtidos pela AACPD. 


\section{CARACTERIZAÇÃO MORFOLÓGICA E MOLECULAR DE ISOLADOS BRASILEIROS DE Cercospora zeae-maydis}

\section{Resumo}

Sessenta e nove isolados monospóricos de Cercospora zeae-maydis foram obtidos a partir de folhas com sintomas típicos de cercosporiose coletadas em campos de produção de milho (Zea mays L.), na região centro-sul brasileira, nos anos de 2001 e 2002. A diversidade genética entre isolados foi analisada através da digestão da região ITS-5.8S do DNA ribossomal com enzimas de restrição e da análise de 104 locos AFLP. Produção de cercosporina e comprimento, largura e número de septos de conídios foram mensurados para averiguar diferenças bioquímicas e morfológicas entre os isolados. Dois grupos (l e II) foram detectados com base nos padrões de fragmentos gerados por Taql, padrões estes similares aos relatados nos EUA. A distinção dos dois grupos foi confirmada através da análise fenética obtida a partir dos locos AFLP, sendo a similaridade genética entre eles de 35\%, segundo coeficiente de Dice. Os isolados foram geneticamente homogêneos dentro dos grupos, com similaridade média de 93,5\% e 92\%, respectivamente dentro dos grupos I e II. Houve baixa similaridade genética entre estes e um terceiro grupo, formado por dois isolados de C. sorghi f. sp. maydis, utilizados como controle, sendo de $45 \%$ para o grupo I e $35 \%$ para o II. Somente isolados do grupo I produziram cercosporina em meio de cultura. Foram detectadas 
diferenças significativas para a variável comprimento de conídios entre os grupos, sendo este o primeiro relato de tal fato. Isolados do grupo I apresentaram comprimento médio de $50,23 \mu \mathrm{m}$, ao passo que o grupo II, de 47,12 $\mu \mathrm{m}$. Os resultados indicaram que a população brasileira de C. zeaemaydis é semelhante àquela existente nos Estados Unidos e na África.

\section{Morphological and molecular variability of Brazilian isolates of Cercospora zeae-maydis}

\section{Summary}

Sixty-nine monoconidial isolates of Cercospora zeae-maydis were isolated from diseased leaves displaying typical gray leaf spot symptoms, collected in maize producing areas of center-south Brazil in 2001 and 2002. The genetic variability among isolates was analyzed by digesting the ITS (internally transcribed spacer) region of the ribossomal DNA with restriction enzymes and also by analysing 104 AFLP loci. Cercosporin production and length, width and number of septa per conidia were also analyzed. The restriction patterns of Taql enzyme detected the presence of two groups (I and II ) of C. zeae-maydis in Brazil. That have previously been described occurring in the United States. AFLP cluster analysis also confirmed the genetic separation of C. zeae-maydis isolates in two distinct groups. The similarity between groups was $35 \%$. Within groups, the similarity levels were high, averaging 93\% and 92\%, respectively among isolates of group I and II. The genetic similarity between group I and II and two isolates of C. sorghi f. sp. maydis, was $45 \%$ and $35 \%$, respectively. Differences in conidium length were found between groups. The average length of conidia in group I was $50.23 \mu \mathrm{m}$ in contrast to 47.12 in group II. This study showed that Brazilian populations of $C$. zeae-maydis are similar to populations of United States and Africa. 


\subsection{Introdução}

No Brasil, o milho (Zea mays L.) é cultivado principalmente no Sul, Sudeste e Centro-Oeste. Nos últimos dez anos, a produção brasileira experimentou aumento de 50\%, passando de 30 milhões de toneladas na safra 1992/1993 para mais de 47 milhões na safra 2002/2003 (Fao http:Ilwww.fao.org). O aumento da produção deve-se ao desenvolvimento de híbridos mais produtivos e às mudanças nas práticas culturais, como o aumento do plantio de segunda época (safrinha), a expansão da cultura para as regiões de cerrado e a prática do plantio direto. Estas mudanças, no entanto, foram acompanhadas de aumento na incidência de doenças. Em campos de produção dos EUA, vários autores observaram que a manutenção da palhada no campo associada a monocultura de milho favore a manutenção e o incremento de inóculo no campo, aumentando significativamente a incidência e a severidade de doenças (Roane et al., 1974; Latterel \& Rossi, 1983; Payne \& Waldron, 1983; Payne et al., 1987).

A mancha de cercospora sempre foi caracterizada como uma doença de pouca importância para o milho no Brasil, desde seu primeiro relato em 1953 (Chupp, 1953). Contudo, a ocorrência de severas epidemias nas safras de 2000 e 2001 levaram-na a ser considerada uma das mais importantes doenças foliares da cultura da atualidade (Fantin et al., 2001). A doença é causada por Cercospora zeae-maydis Tehon \& Daniels e Cercospora sorghi f. sp. maydis Ellis \& Everh (Chupp, 1953). Porém, observações realizadas em plantios comerciais indicaram que $C$. zeae-maydis é a espécie predominante (Fantin et al., 2001). Embora fatores ambientais e culturais possam ter contribuído para os surtos epidêmicos recentes, mudanças genéticas na população do fungo devem ser consideradas.

A diversidade genética de $C$. zeae-maydis tem sido alvo de estudo de diversos pesquisadores. Carson et al. (1997), utilizando marcadores RAPD, 
separaram isolados americanos de C. zeae-maydis em três grupos geneticamente distintos. Além disto, os autores também observaram variação com relação a produção do pigmento cercosporina em meio BDA. Isolados pertencentes a um dos grupos produziram o pigmento, ao passo que os isolados dos outros não produziram ou o fizeram em pequena quantidade. Estudos posteriores com isolados americanos e africanos realizados através de marcadores AFLP e da digestão da região ITS-5.8S do rDNA com enzimas de restrição, reclassificaram os isolados de C. zeae-maydis em dois grupos geneticamente distintos (Wang et al., 1998; Dunkle \& Levy, 2000). Estes estudos indicam que os dois grupos podem ser classificados como espécies afins ou "sibling", pois apesar de serem morfologicamente idênticos, são geneticamente distintos. As pesquisas realizadas por Wang et al. (1998) indicaram que a população americana de C. zeae-maydis é composta pelos dois grupos genéticos do patógeno. No entanto, isolados com padrão genético do grupo I foram encontrados em todas as regiões amostradas, enquanto aqueles do grupo II foram encontrados apenas ao leste do país. Estudos realizados por Dunkle \& Levy (2000) com isolados africanos, demonstraram que a população de C. zeae-maydis é composta unicamente por isolados do grupo II. Em ambos estudos, houve alta similaridade genética entre os isolados de cada agrupamento (sempre maior que 90\%), o que pode ser decorrência da baixa capacidade de recombinação e/ou mutação destes isolados. No Brasil, inexistem trabalhos sobre a composição genética da população de $C$. zeaemaydis.

Para culturas como a do milho, onde o controle de doenças faz-se basicamente através de resistência genética, o conhecimento da composição genética de populações de fitopatógenos é medida fundamental para a seleção de genes de resistência mais estáveis e duráveis. Deste modo, este trabalho objetivou determinar o grau de variabilidade morfológica e genética de um grupo de 69 isolados de C. zeae-maydis, coletados em diversas localidades da 
região centro-sul brasileira, e averiguar a presença e distribuição dos grupos descritos por Wang et al. (1998) nas áreas de amostragem.

\subsection{Material e Métodos}

\subsubsection{Isolamento e cultivo de C. zeae-maydis}

Uma coleção de 69 isolados monoconidiais de C. zeae-maydis (Tabela 6; Anexo) foi obtida a partir de isolamento direto de folhas de milho com sintomas da doença. Estas folhas foram coletadas de híbridos comerciais e experimentais de áreas produtoras da região centro-sul do Brasil (regiões Sul, Sudeste e Centro-Oeste). Para tanto, conídios foram retirados das lesões, transferidos para meio BDA e incubados por três a cinco dias a $27^{\circ} \mathrm{C}$ até a formação de colônias típicas. A partir destas colônias, frações de hifas foram repicadas para meio $\mathrm{V} 8$ e incubadas a mesma temperatura sob fotoperíodo de 12 horas por oito dias para esporulação e análises morfológicas. Para efeito de comparação genética, DNA de quatro isolados americanos e dois africanos de C. zeae-maydis, previamente classificados dentro dos grupos genéticos I e II descritos por Wang et al. (1998), e dois de C. sorghi f sp. maydis também foram adicionados ao estudo para efeitos comparativos (Tabela 6; Anexo).

\subsubsection{Isolamento do DNA}

Micélio fúngico foi obtido a partir de culturas incubadas em $200 \mathrm{~mL}$ de meio BD (batata-dextrose) sob luz contínua a temperatura de $27^{\circ} \mathrm{C}$ sem agitação por 14 dias. O micélio foi filtrado, lavado com água estéril, depositado sob papel de filtro para remoção do excesso de água e liofilizado em tubos do tipo Falcon $50 \mathrm{~mL}$ em aparelho Heto FD3 (Heto-Holten A/S - Dinamarca). O DNA foi extraído de aproximadamente 100 mg de micélio macerado em $600 \mu \mathrm{L}$ 
de solução tampão de extração (10mM de Tris- $\mathrm{HCl}$ pH 8,0, 100mM de EDTA e $0,5 \%$ de SDS) previamente aquecida a $60^{\circ} \mathrm{C}$, segundo Reader (1985). Essa suspensão foi incubada por 30 minutos a $65^{\circ} \mathrm{C}$ e o DNA extraído com três lavagens de fenol-clorofórmio-alcool isoamílico (25:24:1). A precipitação foi feita com $400 \mu \mathrm{L}$ de etanol absoluto. O DNA foi ressuspendido em $100 \mu \mathrm{L}$ de TE $\mathrm{pH}$ $8.0(10 \mathrm{mM}$ de Tris- $\mathrm{HCl}$ e $1 \mathrm{mM}$ de EDTA) e tratado com $1 \mathrm{mg} / \mathrm{mL}$ de RNAse por 4 horas a $35^{\circ} \mathrm{C}$. O DNA foi quantificado por eletroforese em gel de agarose 1,0\% corado com brometo de etídio $(0,5 \mu \mathrm{g} / \mathrm{mL})$ em tampão 1X TBE (100mM de Tris base, 100mM de ácido bórico e $2 \mathrm{mM}$ de EDTA pH 8,0), tendo como padrão fragmentos de DNA de fago $\lambda$ com concentrações conhecidas $(25,50$ e $100 \mathrm{ng} / \mu \mathrm{L})$.

\subsubsection{Digestão da região ITS-5.8S do rDNA com enzimas de restrição}

Os isolados foram analisados com base no polimorfismo de comprimento por restrição (RFLP) da região ITS-5.8S do rDNA após digestão com a enzima de restrição Taql (New England - Biolabs ), de acordo com Wang et al. (1998). Além desta, outras cinco enzimas (Msel, Bfal e Ddel - New England - Biolabs; Hhal e Haell - MBI Fermentas) foram utilizadas para averiguar a existência de padrões de restrição que diferenciasse os isolados em grupos ainda não descritos. Para tanto, o DNA foi amplificado via PCR com os iniciadores ITS4 (TCC TCC GCT TAT TGA TAT GC) e ITS5 (GGA AGT AAA AGT CGT AAC AAG G) (Dunkle \& Carson, 1998). A reação foi realizada em volume final de $50 \mu \mathrm{L}$ seguindo protocolo descrito por Miller et al. (1999). Dois microlitos do produto amplificado foram submetidos a eletroforese em gel de agarose $1 \%$ corado com brometo de etídio $(0,5 \mu \mathrm{g} / \mathrm{mL})$ em tampão 1X TBE para estimativa do peso molecular através do padrão $1 \mathrm{~kb}$ (Promega). As digestões enzimáticas foram realizadas em volume final de $20 \mu \mathrm{L}$ com cinco microlitros do

produto da PCR não purificado e oito unidades de cada endonuclease de restrição. Os fragmentos de restrição foram separados em gel de agarose 3\%, 
corados com brometo de etídeo $(0,5 \mu \mathrm{g} / \mathrm{mL}$ de gel) e fotografados em aparelho ImageMaster ${ }^{\circledR}$ VDS (Pharmacia Biotech) sob luz UV.

\subsubsection{Análise da variabidade genética através de marcadores AFLP}

Marcadores moleculares AFLP foram utilizados para determinar a variabilidade genética dos isolados, seguindo o protocolo adaptado de Vos et al. (1995). O DNA genômico foi digerido com as enzimas de restrição EcoRI (New England - Biolabs) e Msel (New England - Biolabs) e ligados na terminação 3' com os adaptadores específicos para cada enzima (EcoRI 5'CTCGTAGACTGCGTACC- 3' e 3'- CATCTGACFCATGGTTAA- 5' / Msel 5'GACGATGAGTCCTGAG- 3' e 3'- TACTCAGGACTCAT- 5') sob temperatura de $23^{\circ} \mathrm{C}$ por quatro horas. As amostras digeridas e ligadas foram préamplificadas com iniciadores EcoRI (5'- GACTGCGTACCAATTCA) + oligo seletivo A e Msel (5'- GATGAGTCCTGAGTAAC -3') + oligo seletivo A ou C, com as seguintes condições: $94^{\circ} \mathrm{C}$ por 2 minutos, 25 ciclos de $94^{\circ} \mathrm{C}$ por 1 minuto, $56^{\circ} \mathrm{C}$ por 1 minuto e $72^{\circ} \mathrm{C}$ por 1 minuto, seguido de um passo de extensão final de $72^{\circ} \mathrm{C}$ por 5 minutos. Este DNA pré-amplificado foi diluído na

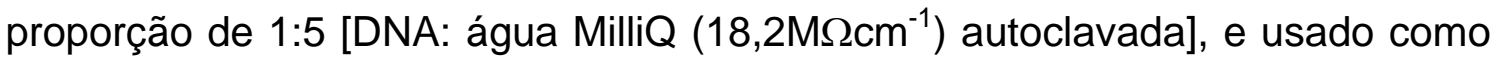
molde para as amplificações seletivas realizadas com iniciador EcoRI mais uma base $(E+A)$ combinado com iniciadores Msel com duas bases ( $M+A T$ ou $M+C A)$. Deste modo, os fragmentos produzidos foram resultados de duas combinações de iniciadores: $E+A / M+A T$ e $E+A / M+C A$, sendo estas as mesmas utilizadas por Wang et al. (1998). O programa de amplificação constou de $94^{\circ} \mathrm{C}$ por 2 minutos, 12 ciclos de $94^{\circ} \mathrm{C}$ por 30 segundos, $65^{\circ} \mathrm{C}$ por 30 segundos e $72^{\circ} \mathrm{C}$ por 1 minuto, mais 23 ciclos de $94^{\circ} \mathrm{C}$ por 30 segundos, $56^{\circ} \mathrm{C}$ por 30 segundos e $72^{\circ} \mathrm{C}$ por um minuto, seguido de extensão final de $72^{\circ} \mathrm{C}$ por 5 minutos.

Os produtos AFLP foram separados em gel desnaturante de poliacrilamida $6 \%$ com tampão $1 \mathrm{X}$ TBE. A eletroforese foi realizada em 
voltagem constante de $80 \mathrm{~W}$ e temperatura máxima de $50^{\circ} \mathrm{C}$ por quatro horas. $\mathrm{O}$ gel foi corado com solução de nitrato de prata e revelado em carbonato de sódio seguindo protocolo descrito por Creste et al. (2001).

Cada fragmento AFLP foi escorado visualmente quanto à presença ou ausência, sendo os padrões AFLP de cada isolado convertidos em dados binários ( $1=$ presença do fragmento e $0=$ ausência). A similaridade genética entre os isolados foi calculada com base na comparação pareada entre locos através do coeficiente de Dice como descrito por Levy et al. (1993). Um agrupamento fenético (dendrograma) foi obtido através do método aritmético não ponderado de determinação de grupos (UPGMA). As análise foram realizadas com o software estatístico NTSYSpc versão 1.8 (Exeter Software, Setauket, NY) e a construção do dendrograma com o programa MEGA II versão 2.1 (Kumaar et al., 2001).

\subsubsection{Análises morfométrica de conídios e de produção de cercosporina}

Fragmentos miceliais foram transferidos para meio BDA e incubados a $27^{\circ} \mathrm{C}$ por 14 dias sob luz contínua para avaliação da produção de cercosporina (Wang et al., 1998). Os isolados receberam notas de um a quatro, dependendo da quantidade aparente do pigmento lançado no meio de cultura. Nota um foi atribuída a isolados com nenhuma produção do pigmento, dois a isolados cujo pigmento apenas circundou a colônia, três a isolados cuja pigmentação tomava metade da placa e quatro para aqueles onde o meio de cultivo mostrava-se totalmente tomado pela coloração púrpura.

Para a análise morfológica, frações de hifas foram repicadas para placas de Petri Pyrex ${ }^{\circledR}$ contendo meio V8 e incubadas a $27^{\circ} \mathrm{C}$ sob fotoperíodo 12/12h (luz/escuro) por oito a dez dias para determinação da largura, comprimento e número de septos de 150 conídios/isolado. As mensurações foram realizadas com auxílio de um microscópio Zeiss Axioshop2 com aumento de 400x acoplado a um computador contendo o software AxioVision 2.0.5.3 
(Carl Zeiss Vision - GMbH). Para averiguação de diferenças morfométricas entre os grupos genéticos, foram calculadas as médias para largura, comprimento e número de septos para cada isolado e os dados submetidos a análise de variância através da função PROC GLM do programa estatístico SAS versão 8.0 (SAS Institute, Cary, NC).

\subsection{Resultados}

Todos os isolados foram obtidos de lesões típicas da mancha de cercospora. Os esporos foram coletados a partir de conidióforos organizados em esporodóquios, que emergiam da cavidade substromática da folha. Os conidióforos se mostraram não ramificados e de coloração verde oliva. Os conídios foram hialinos, de formato obclavados e com as medidas conidiais e números de septos característicos e consistentes com as descrições para $C$. zeae-maydis (item 5.3. 3).

\subsubsection{Análise das regiões ITS e 5.8S do rDNA por RFLP}

Em todos os isolados de Cercospora utilizados neste estudo, um único fragmento de aproximadamente $520 \mathrm{pb}$ foi amplificado com os iniciadores ITS4 e ITS5, tamanho que corresponde ao esperado para esta região do rDNA (duas regiões espaçadoras mais a sub-unidade 5.8S) quando acompanhada de pequenas porções de rDNA das subunidades 18s e 28s usadas para ancoragem dos iniciadores (Wang et al., 1998). A digestão dos fragmentos de DNA com a enzima de restrição Taql gerou três padrões diferentes (Figura 2). Estes correspondem aos dos grupos I e II de C. zeae-maydis e de C. sorhi, segundo Wang et al. (1998). No total, 41 isolados foram classificados como pertencentes ao grupo I, 28 ao grupo II e dois à espécie C. sorghi f. sp. maydis. Como esperado, os dois isolados africanos (5-34, 5-24) e um americano (19) 
apresentaram padrão de restrição típico do grupo II, enquanto os outros três americanos (1-5, 14B e 11B) apresentaram padrão típico do grupo I. Das outras cinco enzimas de restrição testadas, apenas Bfal não encontrou sítios de cortes no produto amplificado. Hhal produziu padrão RFLP idêntico para todos os isolados. A enzima Msel produziu perfil enzimático capaz de diferenciar os isolados dos dois grupos de C. zeae-maydis, mas incapaz de diferenciar o grupo II da espécie $C$. sorghi f. sp. maydis. Comportamento contrário foi observado pelos fragmentos produzidos por Haell e Ddel, onde o padrão RFLP destas enzimas distinguiu os dois grupos de C. zeae-maydis, mas não diferenciou o grupo I da espécie $C$. sorghi f. sp. maydis (Figura 2). 


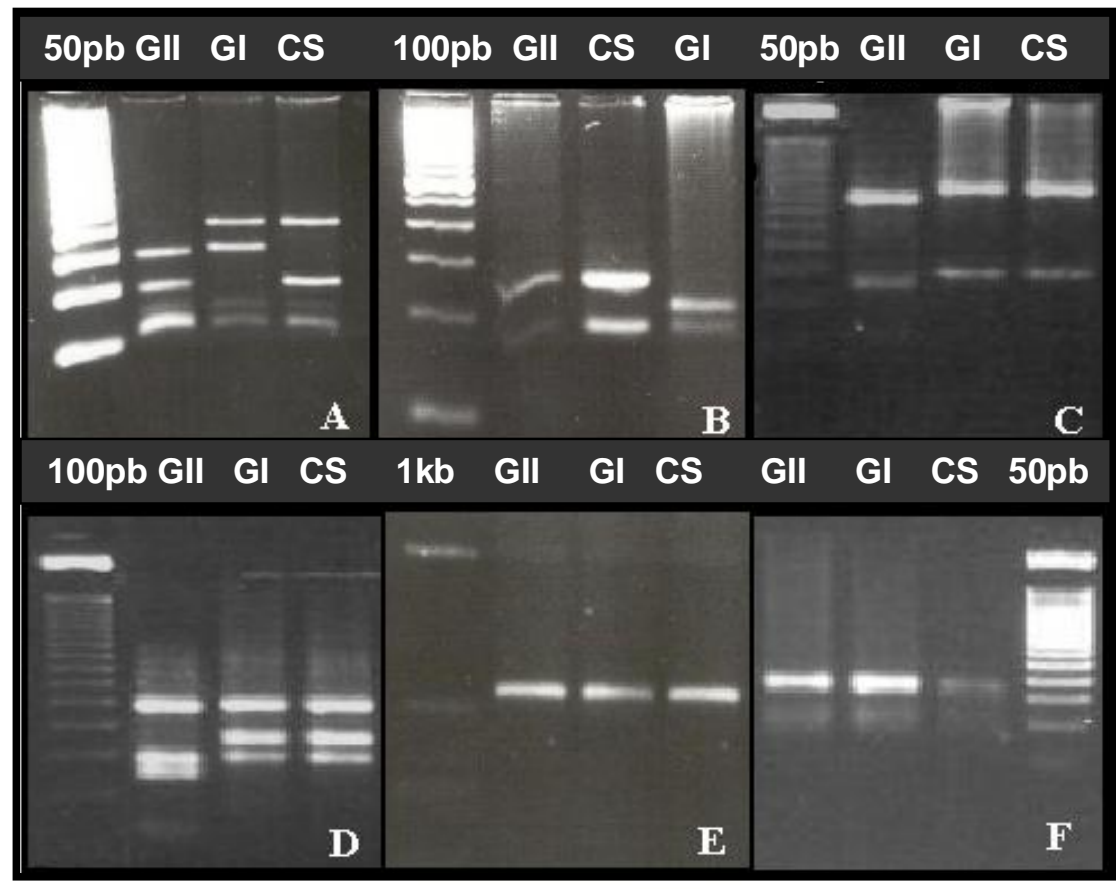

Figura 2 - Padrões de restrição obtidos com as seis enzimas para isolados de C. zeae-maydis do grupo II (GII), isolados de C. zeae-maydis do grupo I (GI) e para isolado de C. sorghi f. sp. maydis (C.S.). $\mathbf{A}=$ enzima Taql (note o padrão diferencial para os grupos e espécies); $\mathbf{B}=$ Msel; $\mathbf{C}=$ Ddel; $\mathbf{D}=$ Haell; $\mathbf{E}=$ Bfal (fragmento com 520pb enzima não encontrou sítio de corte na região ITS) e F = Hhal

\subsubsection{Análise da variação genética através de marcadores AFLP}

As duas combinações de iniciadores produziram um grande número de fragmentos. Para comparação dos isolados, foram selecionados 104 fragmentos considerados confiáveis por serem de fácil visualização, com pesos moleculares variando de 50 a 350 pb. Os isolados foram agrupados em dois grupos, com uma similaridade genética de 35\% em média entre eles, calculada pelo índice de Dice (Figura 3). No primeiro "cluster", foram agrupados apenas 
isolados que obtiveram padrão RFLP do grupo II de C. zeae-maydis, ao passo que no segundo, apenas isolados com padrão do grupo I. A média de similaridade entre isolados do grupo II foi de $92 \%$ e do grupo I de $93,5 \%$. Houve alta similaridade genética entre os isolados brasileiros e os americanos e africanos utilizados como controle. No grupo I, a identidade entre isolados do Brasil e dos Estados Unidos foi de 90\%. No grupo II, os isolados africanos foram $89 \%$ similares aos brasileiros, ao passo que o americano foi $90,2 \%$. Um terceiro grupo, composto pelos dois isolados de $C$. sorghi f. sp. maydis, apresentou similaridade média de $45 \%$ e $35 \%$, respectivamente, para isolados do grupo I e II. Isolados representantes de cada grupo estão presentes na Figura 4 com seus respectivos padrões eletroforéticos para as duas combinações de iniciadores. 


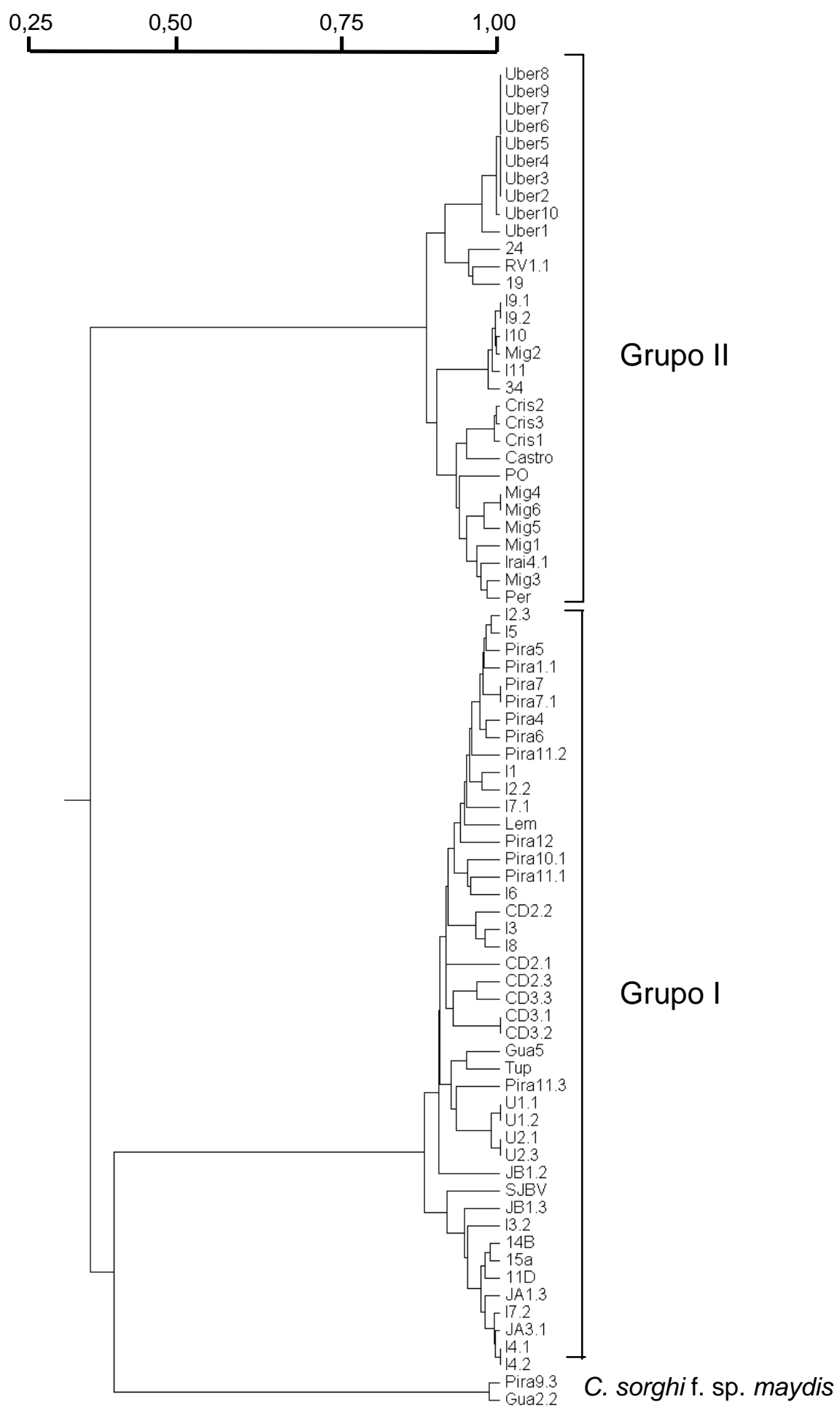

Figura 3 - Dendrograma dos isolados de C. zeae-maydis e C. sorghi f. sp. maydis analisados pelas marcas AFLP. A similaridade genética entre os isolados foi estimada pelo coeficiente de Dice e o agrupamento fenético pelo método UPGMA 


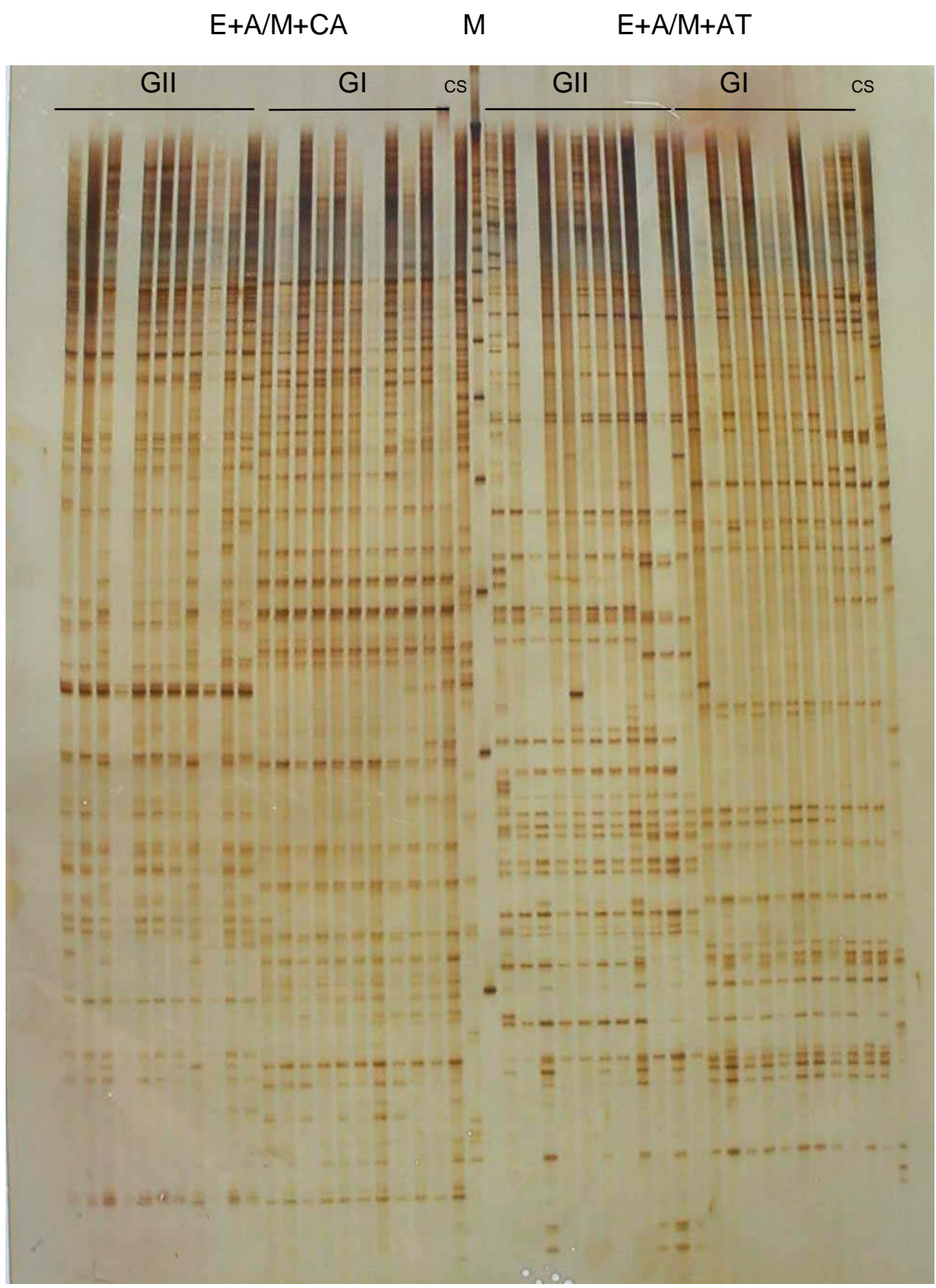

Figura 4 - Eletroforese de fragmentos AFLP amplificados com os iniciadores $\mathrm{E}+\mathrm{A} / \mathrm{M}+\mathrm{AT}$ e $\mathrm{E}+\mathrm{A} / \mathrm{M}+\mathrm{CA}$ de representantes dos isolados pertencentes aos grupos I (GI) e II (GII) de C. zeae-maydis e C. sorghi f. sp. maydis (CS) utilizados neste estudo. $\mathrm{M}=$ marcador molecular de 50pb (Promega) 


\subsubsection{Análise morfométrica de conídios e de produção de cercosporina}

Todos os 69 isolados tiveram adequado crescimento vegetativo em meio BDA, produzindo micélio cinza-esverdeado. Sob as condições de cultivo em meio BDA, foi possível verificar a presença de cercosporina em alguns isolados de C. zeae-maydis. Sessenta e três por cento, ou 26 dos 41 isolados pertencentes ao grupo I, produziram considerável quantidade do pigmento (Tabela 8; Anexo). Não foi observada formação do pigmento em nenhum dos 28 isolados do grupo II.

Quando subcultivados em meio V8, 64 dos 69 isolados de C. zeaemaydis produziram abundante número de conídios. Houve diferença significativa quanto ao comprimento de conídios entre os grupos genéticos I e II $(P \leq 0,05)$, não sendo observado o mesmo para largura de conídios e número de septos/conídios [Tabelas 7 e 8(anexo)].

Tabela 7. Resumo da análise de variância para comprimento e largura de conídios e número de septos/conídios avaliados em 64 isolados de C. zeae-maydis

\begin{tabular}{|c|c|c|c|c|c|c|}
\hline \multirow[b]{2}{*}{ Fonte } & \multicolumn{2}{|c|}{ Comprimento } & \multicolumn{2}{|c|}{ Largura } & \multicolumn{2}{|c|}{$\mathrm{N}^{0}$ de septo } \\
\hline & GL & $\mathrm{QM}$ & GL & QM & $\mathrm{GL}$ & QM \\
\hline Grupo & 1 & $146,85^{\star}$ & 1 & $0,52^{\mathrm{ns}}$ & 1 & $0,17^{\text {ns }}$ \\
\hline Resíduo & 62 & 30,80 & 62 & 0,66 & 62 & 0,40 \\
\hline Média geral & & 49,01 & & 5,95 & & 3,90 \\
\hline Média grupo I & & 50,23 & & 6,02 & & 3,99 \\
\hline grupo II & & 47,12 & & 5,84 & & 3,85 \\
\hline$C V(\%)$ & & 11,30 & & 13,64 & & 16,15 \\
\hline
\end{tabular}

* Significativo a $\mathrm{P} \leq 0,05$ 
5.3.4 Distribuição geográfica dos grupos de C. zeae-maydis no território brasileiro.

Foi possível verificar a presença dos dois grupos genéticos de C. zeaemaydis em todas as regiões de coleta, com exceção do estado de Goiás, onde somente isolados do grupo II foram identificados. Em Minas Gerais, observouse grande número de isolados do grupo II, sendo a relação grupo I/grupo II de 16/23. Em São Paulo, esta relação foi de 6/17 (Figura 5).

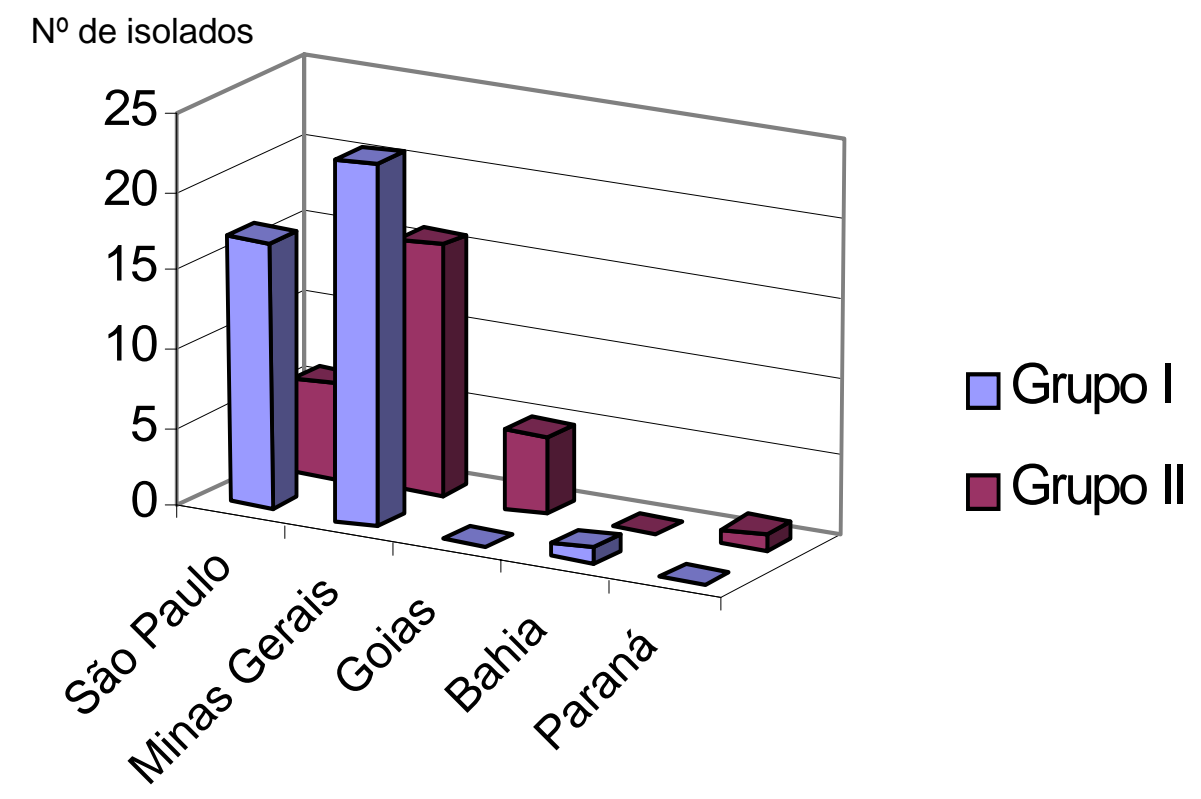

Figura 5 - Distribuição de freqüências dos isolados de C. zeae-maydis, por grupos genéticos, nas regiões brasileiras amostradas 


\subsection{Discussão}

Os isolados que compuseram este estudo foram amostrados em diversos Estados da região centro-sul, responsáveis por grande parte da produção de cereais do país. Com relação as medidas conidiais dos isolados, estas se mostraram compatíveis com as dimensões descritas para a espécie $C$. zeae-maydis. No gênero Cercospora, tamanho de conídios e número de septos podem variar dependendo do substrato e das condições a que os isolados são submetidos. Assim, neste trabalho, a esporulação foi induzida em meio de cultura (V8) e condições ambientais (temperatura de $27^{\circ} \mathrm{C}$ e fotoperíodo $12 / 12 \mathrm{~h}$ ) sugeridos por outros autores em estudos similares (Wang et al., 1998; Dunkle \& Levy, 2000). Nestas condições, foi possível verificar diferenças significativas quanto ao comprimento de conídios entre os grupos I e II de C. zeae-maydis, sendo este o primeiro relato sobre diferenças morfológicas entre os grupos. Embora este fato tenha sido comprovado estatisticamente, a proximidade entre

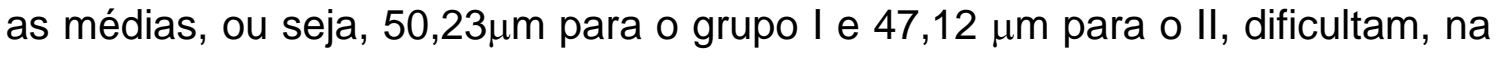
prática, a utilização desta variável para a separação dos grupos. Este resultado

reforça a já relatada divergência genética entre os grupos genéticos (Wang et al., 1998; Dunkle \& Levy, 2000).

Isolados do grupo I produziram abundante quantidade de cercosporina em meio BDA, enquanto nenhum isolado do grupo II o fez eficientemente. Esta característica já havia sido observada por Carson et al. (1998) e por Wang et al. (1998). Especula-se que este produto microbiano funcione como um fator de patogenicidade para aquelas espécies que o produzem (Daub \& Ehrenshaft, 2000), no entanto, nenhum estudo comprovando esta possibilidade foi realizado no patossitema C. zeae-maydis x milho.

Com base nos critérios genético-moleculares, foi possível determinar que a composição da população de C. zeae-maydis, ao menos na área abrangida por este estudo, é semelhante àquela existente nos Estados Unidos, 
verificando-se a presença dos dois grupos genéticos já descritos para a espécie (Wang et al., 1998; Dunkle \& Levy, 2000). Neste estudo, a similaridade genética entre eles, averiguada através de análise de marcas AFLPs, foi de 35\%. Wang et al. (1998) já haviam reportado grande distanciamento genético entre os dois grupos, levando-os a especular a provável divergência biológica entre eles e a considera-los espécies afins (sibling species).

Este estudo também demonstrou a alta similaridade genética entre os isolados brasileiros, americanos e africanos. A similaridade média entre isolados brasileiros e americanos dentro do grupo I foi de $90 \%$, e dentro do grupo II de $90,2 \%$ para o isolado americano e $89 \%$ para os outros dois africanos. Isto demonstra que há pouca variabilidade genética dentro dos grupos de C. zeae-maydis. Porém, a distribuição dos grupos em território brasileiro parece ser bem diferente daqueles encontrados nos EUA e na África. Os trabalhos realizados por Wang et al. (1998) identificaram o grupo II apenas ao Leste do país, enquanto o grupo I foi encontrado em todos os pontos de coleta da região produtora de milho dos Estados Unidos. Na África, por outro lado, Dunkle \& Levy (2000), em estudos posteriores, demonstraram que a população africana de C. zeae-maydis é composta unicamente por representantes do grupo II. No Brasil, isolados dos dois grupos foram encontrados em toda a área coberta pela pesquisa, ou seja, mais de $1500 \mathrm{~km}$ entre os pontos extremos de coleta, com exceção do Estado de Goiás, onde apenas isolados do grupo II foram identificados.

Diante da grande divergência genética entre os grupos genéticos de $C$. zeae-maydis, muitas especulações acerca da provável origem destas espécies afins foram realizadas. Ward et al. (1999) foram os primeiros a sugerir que o inóculo inicial para a pandemia ocorrida na África na década de 80 , foi proveniente de resíduos de milho importado dos Estados Unidos. Entretanto, com exceção da parte Leste dos EUA onde foram identificados isolados do grupo II, a população americana de C. zeae-maydis é composta basicamente por isolados do grupo I (Wang et al., 1998), enquanto as epidemias ocorridas na 
África foram reportadas ao grupo II (Dunkle \& Levi, 2000). Esta observação levou Dunkle \& Levi (2000) a sugerirem que a provável origem do grupo II tenha sido na África, e que a migração tenha ocorrido do continente Africano para os Estados Unidos. Deste modo, há um consenso (Wang et al., 1998; Dunkle \& Levi, 2000) entre os pesquisadores de que a origem do grupo I tenha sido o continente Americano, mas a origem do grupo II ainda é duvidosa. Os próprios Dunkle \& Levi (2000) sugerem que uma terceira, e ainda não identificada, rota migratória dos isolados do grupo II possa existir. Via de regra, os centros de origens das espécies têm maior diversidade genética em comparação aos outros locais para onde estas espécies migraram. Desta maneira, esta terceira possibilidade levantada por Dunkle \& Levi (2000) pode ser representada pelo Brasil. Aqui, ao contrário dos Estados Unidos e da África, a presença dos grupos genéticos deu-se em todas as regiões de coleta. Portanto, isolados do grupo II podem ter sido levados do Brasil para a África, e lá encontrado condições ambientais adequadas para seu estabelecimento. $\mathrm{O}$ mesmo pode ter acontecido entre o Sul e o Norte do continente americano.

Roane (1950) relata que maior severidade da mancha de cercospora é freqüentemente associada a ausência de outros patógenos foliares, pela maior disponibilidade de tecidos adequados a colonização. Deste modo, o desenvolvimento de híbridos com maior nível de resistência a patógenos capazes de ocupar grandes áreas de tecido foliar pode ter contribuído para o incremento da mancha de cercospora (Wang et al.,1998). Diante destes fatos, é provável que os surtos epidêmicos ocorridos no país a partir de 2000 sejam decorrência desta maior quantidade de tecido sadio associado ao incremento de inóculo promovido pelas práticas culturais de plantio direto, irrigação por pivô e pela safrinha. Muito provavelmente a elevação dos níveis de doença deu-se de forma gradual, mas só chamou a atenção dos produtores quando os níveis de doença chegaram a patamares alarmantes.

Embora a capacidade de recombinação genética, seja por via sexual ou parassexual, seja descrita como mínima para esta espécie (Dunkle \& Carson, 
1998), não se conhece ainda a habilidade destas duas espécies afins de gerar novos patótipos. Desta maneira, é justificável o contínuo monitoramento da população de $C$. zeae-maydis, para que se houver a presença de novos patótipos, estes sejam rapidamente identificados e genes de resistência a eles, incorporados nos programas de melhoramento

\subsection{Conclusões}

1. Foi possível verificar a existência dos grupos I e II de C. zeaemaydis em território brasileiro, através da análise de RFLP da região ITS do rDNA

2. Os dois grupos genéticos ocorreram em todas as regiões de coleta, com exceção do estado de Goiás, onde apenas isolados do Grupo II foram identificados.

3. Há pouca variabilidade genética dentro de cada uma das espécies afins (ou grupos genéticos) de C. zeae-maydis no Brasil, África e Estados Unidos.

4. Por haver presença generalizada de ambos grupos genéticos em todas as regiões de coleta do território brasileiro, diferentemente do que ocorre nos Estados Unidos e na África, é provável o grupo II seja originário do território brasileiro. 


\section{ANÁLISES MICROSCÓPICAS DA GERMINAÇÃO, PENETRAÇÃO E CONIDIAÇÃO MICROCÍCLICA DE Cercospora zeae-maydis}

\section{Resumo}

O sucesso no estabelecimento de uma relação parasitária entre fungos e plantas depende, em muitos casos, de eventos que antecedem a infecção. Neste trabalho, foram observados aspectos microscópicos de Cercospora zeaemaydis relacionados a fase de pré-penetração em folhas de milho e em meio de cultura. Plantas de um híbrido suscetível foram cultivadas em casa de vegetação e inoculadas com $300 \mu \mathrm{L}$ de uma suspensão de $10^{5}$ conídios $/ \mathrm{mL}$ ao atingirem seis folhas expandidas. Amostras de discos foliares foram coletadas 10, 13, e 16 horas após a inoculação e preparadas para análise ao microscópio eletrônico de varredura. Noventa e cinco por cento dos conídios germinaram 13 horas após a inoculação. Também foi observada formação de estruturas similares a apressórios, provavelmente envolvidas na fixação do fungo na hospedeira. Penetração via estômato foi observada 16 horas após a inoculação. Num segundo ensaio, 64 isolados do fungo, previamente classificados como pertencentes aos grupos genéticos I e II (Capítulo 5) foram cultivados em meio V8 a $27^{\circ} \mathrm{C}$ por oito dias e avaliados quanto a capacidade de produzir conídios secundários (microconídios) diretamente a partir da germinação do conídio primário sem fase vegetativa intermediária. Os conídios foram retirados das colônias com auxílio de fita adesiva e um mínimo de 150 conídios por isolado foi 
observado em microscópio de luz em aumento de 400x. Isolados que apresentaram conidiação microcíclica foram observados ao microscópio eletrônico de varredura. Vinte e seis por cento dos isolados pertencentes ao grupo I produziram microconídios, ao passo que nenhum do grupo II apresentou esta característica. Este é o primeiro relato de conidiação microcíclica no grupo I e ausência no grupo II.

\section{Microscopical investigation of germination, penetration and microcyclical conidiation of Cercospora zeae-maydis}

\section{Summary}

The successful establishment of plant-pathogen relationships depends on pre-infection events. In this work, aspects of pre-penetration of $C$. zeaemaydis in leaves of a susceptible hybrid maize were microscopically analysed. Plants of a susceptible hybrid were inoculated with $300 \mathrm{~mL}$ of conidial suspension adjusted to $10^{5}$ conidia/mL at the six leaf stage. Samples of leaf tissue were collected at 10,13, and 16 hours after inoculation and analysed in a scanning electron microscope. Ninety-five percent of the conidia germinated 13 hours after inoculation. Apressoria-like structures were observed at this time, which are probably involved in fungal adhesion to the host. Penetration through stomata was observed at 16 hours after inoculation. In a second experiment, sixty-four isolates of $C$. zeae-maydis, previous classified as either genetic group I or II (chapter 5), were cultivated on V8 media at $27^{\circ} \mathrm{C}$ for eight days and examined for their ability to produce secondary conidia (microconidia) directly from germinated primary conidia without an intervening vegetative phase. We observed 150 conidia/isolate under light microscope. Isolates that produced microconidia were further observed in the scanning electron microscope. 
Twenty-six percent of isolates from group I produced microconidia, while none of group II did. This is the first report of the occurrence of microcyclical conidiation in group I and absence in group II.

\subsection{Introdução}

Epidemias severas de mancha de cercospora, causada pelo fungo Cercospora zeae-maydis Tehon \& Daniels, foram observadas na cultura do milho nas safras de 2000 e 2001, causando impacto negativo na produtividade de importantes regiões agrícolas do Brasil (Fantin et al. 2001). Mesmo com o desenvolvimento de híbridos mais resistentes, ainda hoje essa doença causa danos à cultura na região Centro-Oeste. Os sintomas são caracterizados por manchas retangulares geralmente delimitadas pelas nervuras (Latterel \& Rossi, 1983) e com coloração palha a verde-oliva que, sob condições de alta umidade relativa, tornam-se cinzentas devido à intensa produção de esporos (Chupp, 1953). Sob condições favoráveis, o número de lesões cresce rapidamente e estas, ao coalescerem, causam extensas áreas necróticas no tecido foliar.

O ciclo da doença tem início a partir dos conídios produzidos em restos culturais contaminados. Esses esporos são disseminados pelo vento e alcançam as primeiras folhas da planta. Para germinar e penetrar na hospedeira, esporos de C. zeae-maydis necessitam de períodos relativamente longos de alta umidade, sem a presença de água livre na planta (Beckman \& Payne, 1983; Ringer \& Grybauskas, 1995). Sob condições ideais de temperatura e umidade, são necessários 14 a 28 dias para que o patógeno complete seu ciclo (Beckman \& Payne, 1982; Beckman \& Payne, 1983; Ward et al., 1999).

Quando condições ambientais adversas, como baixa umidade relativa ou aumento repentino na temperatura, ocorrem após a germinação, pode haver colapso dos esporos, das hifas infectivas e dos apressórios, o que pode impedir 
o estabelecimento da doença (Griffin, 1994). Esta é a fase mais crítica do ciclo do patógeno. Muitos estudos têm sido desenvolvidos utilizando microscopia eletrônica de varredura para estudar os eventos que ocorrem nesta fase (Shankar et al., 1998; Kropp et al., 1999; Hsieh et al., 2001; Van de Graaf et al., 2002; Kumar \& Gupta, 2002). No patossistema milho x C.zeae-maydis, Beckman \& Payne (1981) foram os primeiros a observar aspectos relacionados ao crescimento micelial do fungo na superfície da hospedeira utilizando esta metodologia.

Algumas espécies fúngicas possuem estratégias que aumentam seu tempo de sobrevivência durante períodos de estresse físico ou nutricional que ocorrem em momentos que antecedem a germinação (Anderson \& Smith, 1971). Umas destas estratégias é a conidiação microcíclica (Rossier et al., 1977; Stavely \& Nimmo, 1968), definida como produção de esporos secundários (microconídios) a partir da germinação conidial, sem a intermediação de fases vegetativas (hifas) (Hanlin, 1994), como normalmente ocorre no ciclo normal de vida. Tal processo de reprodução assexual foi descrito em muitas espécies de fungos, incluindo alguns patógenos de plantas como Aspergillus niger (Anderson \& Smith, 1971), Penicillium digitarum (Zeidler \& Margalith, 1973), Claviceps sorghi (Bandyopadhyay et al., 1990), Colletotrichum acutatum (Leandro et al., 2001), C. beticola (Rathaiah, 1977) e C. kikuchii (Fernandez et al., 1991). Em C. zeae-maydis, este fenômeno foi relatado pela primeira vez por Lapaire \& Dunkle (2003), que verificaram a produção de esporos secundários após terem submetidos conídios a estresse nutricional. Estes autores também relataram que a germinação de esporos originados da conidiação microcíclica ocorreu adequadamente até a quarta geração, sendo reduzida significativamente a partir deste ponto. Neste estudo, cada geração levou três a quatro dias para produzir novos microconídos. Deste modo, flutuações ambientais ou nutricionais que inibam a infecção, ocorridas durante uma quinzena de dias, não implicarão em redução do inóculo e a epidemia poderá ser retomada quando novamente houver condições ideais. 
Com base no exposto, este trabalho teve como objetivos (i) verificar o tempo de germinação, de formação de estruturas infectivas e de penetração de C. zeae-maydis em um híbrido suscetível, utilizando microscopia eletrônica de varredura e (ii) observar a formação de microconídios a partir de conidiação microcíclica em um grupo de 64 isolados brasileiros de C. zeae-maydis, caracterizados previamente como pertencentes aos grupos genéticos I e II (Capítulo 5).

\subsection{Material e Métodos}

\subsubsection{Germinação dos conídios e penetração de C. zeae-maydis em folhas de milho}

\subsubsection{Isolado}

O isolado monospórico utilizado neste estudo foi o Uber-6, proveniente do município de Uberlândia-MG. Este foi escolhido por apresentar abundante esporulação em meio de cultura e comprovada patogenicidade. Em estudo prévio, realizado através de análise de RFLP da região ITS do rDNA (Capítulo 5), este isolado foi classificado como pertencente ao grupo II de C. zeaemaydis. O mesmo foi cultivado em placas de Petri Pyrex® contendo meio V-8, durante oito dias, quando foi observada abundante produção de esporos. Os esporos foram retirados das colônias com o auxílio de uma lâmina de vidro e suspensos em água a uma concentração de $10^{5}$ conídios $/ \mathrm{mL}$ adicionada de $0,1 \%$ de espalhante adesivo Tween. 


\subsubsection{Material vegetal}

O híbrido utilizado foi o DAS-8432 (Dow Agrosciences), altamente suscetível a mancha de cercospora. Em avaliações prévias, este genótipo apresentou nota 7 em escala de notas de severidade variando de 1 (ausência de doença) a 9 (75\% dos tecidos afetados) (Agroceres, 1996). Este híbrido caracteriza-se por apresentar abundante número de lesões alongadas e típicas com produção de grande número de esporos.

Sementes deste híbrido foram semeadas em vasos de alumínio com capacidade para dois quilos de solo. As plantas foram mantidas em casa de vegetação, sob temperatura entre $28^{\circ}$ e $32^{\circ} \mathrm{C}$ e condições naturais de fotoperíodo por 40 dias, até atingirem o estádio vegetativo de seis folhas completamente expandidas.

\subsubsection{Inoculação, coleta das folhas e observação ao microscópio eletrônico de varredura.}

As plantas foram previamente preparadas de acordo com metodologia descrita por Brunelli et al. (2002), a qual constituiu na fixação de duas placas de acrílico, sendo uma na parte abaxial da folha contendo um orifício central de 0,7 $\mathrm{cm}$ de diâmetro, por onde foram injetados $300 \mu \mathrm{L}$ de uma suspensão de $10^{5}$ conídios $/ \mathrm{mL}$, e a outra na parte oposta, sem nenhuma perfuração, servindo apenas de apoio para fixação da primeira (Figura 6). As plantas foram mantidas sob as condições de cultivo descritas previamente durante todo o tempo de execução do experimento. 


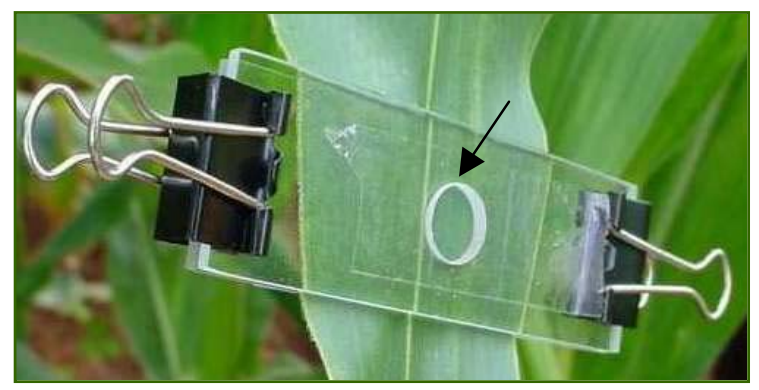

Figura 6 - Método de inoculação utilizado no estudo de microscopia eletrônica de varredura com o uso de gabaritos de acrílico e presilhas. O inóculo foi injetado no orifício central (seta). A parte da folha que ficou exposta ao inóculo compôs o campo amostral

O tecido foliar foi coletado às 10,13 e 16 horas após a inoculação, através do corte da área foliar que recebeu o inóculo (Figura 6). Após cada coleta, os fragmentos foliares foram imediatamente acondicionados em tubos eppendorf contendo uma solução de glutaraldeído-formaldeído $(2,5 \%$ de glutaraldeído, 2,0\% de formaldeído, 0,05M de cacodilato de sódio pH 7,2 e $0,001 \mathrm{M}$ de $\mathrm{CaCl}_{2}$ ) para conservação e fixação dos esporos e tecidos vegetais.

As amostras foram processadas de acordo com protocolo adaptado de Kitajima \& Leite (1999), que constou da fixação inicial por glutaraldeídoformaldeído, seguido de três passagens de 10 minutos em tampão cacodilato 0,05M e imersão numa solução de tetróxido de ósmio (1\% tetróxido de ósmio, 0,05M de cacodilato $\mathrm{pH} 7,2$ ). Em seguida, as amostras foram lavadas em água destilada e imersas em soluções de concentrações crescentes de acetona (30, 50, 70, 90 e 100\%) por 10 minutos cada, sendo a seguir secas ao ponto crítico por sucessivas lavagens com gás carbônico, em aparelho Balzers CPD 030. Logo após a secagem, as amostras foram fixadas e metalizadas com ouro em aparelho MED010-Balzers (gás argônio a 50 mA de corrente e 180 segundos). 
Todo o campo foliar que recebeu a suspensão de esporos foi observado em micróscópio eletrônico de varredura. Os aumentos variaram de 300 a 5.000 vezes, dependendo do grau de detalhamento exigido. Para definir o intervalo de tempo entre inoculação e germinação, 50 conídios foram amostrados aleatoriamente do campo foliar em cada tempo de coleta. Como esporo germinado, considerou-se aquele cujo comprimento do tubo germinativo foi igual ou superior à metade de seu próprio comprimento.

\subsubsection{Conidiação microcíclica em isolados de C. zeae-maydis}

\subsubsection{Isolados}

Sessenta e quatro isolados, coletados em diversas localidades das regiões Centro-Oeste, Sul e Sudeste brasileiras foram analisados quanto a capacidade de conidiação microcíclica. Estes isolados fazem parte da coleção de fungos do Departamento de Entomologia, Fitopatologia e Zoologia Agrícola da ESALQ-USP e foram previamente classificados dentro dos grupos genéticos I e II (Wang et al., 1998), por meio da análise de RFLP da região ITS do rDNA (Capítulo 5). O cultivo dos mesmos foi realizado em placa de Petri Pyrex ${ }^{\circledR}$ contendo meio V8 (100 $\mathrm{ml}$ de suco V8-Campbell; $1,2 \mathrm{~g}$ de $\mathrm{CaCO}_{2}, 8 \mathrm{~g}$ de ágar, $400 \mathrm{ml}$ de água) sob fotoperíodo (12h/12h) a $27^{\circ} \mathrm{C}$ por 8 a 10 dias (Capítulo 3).

\subsubsection{Análises microscópicas}

Os conídios foram retirados das colônias com o auxílio de fita adesiva, fixados em lactofenol e observados ao microscópio de luz em aumento de 400x. Pelo menos 150 conídios por isolado foram analisados nesta fase do trabalho.

Isolados que apresentaram conidiação microcíclica também foram observados ao microscópio eletrônico de varredura. Para tanto, frações de colônias contendo os esporos foram colocadas em fita adesiva de carbono e 
expostas ao vapor de ósmio (1\% tetróxido de ósmio, 0,05M de cacodilato $\mathrm{pH}$ $7,2)$ durante 10 horas. Após este período, as amostras foram metalizadas com ouro em aparelho MED010-Balzers (gás argônio a 50 mA de corrente por 180 segundos) e observadas em microscópio eletrônico de varredura de pressão variável (Leo-435 VP).

\subsection{Resultados}

\subsubsection{Germinação e penetração de $C$. zeae-maydis em folhas de milho}

Um dos primeiros passos para uma bem sucedida interação plantafungo é a germinação das estruturas infectivas deste último. Nas condições experimentais deste trabalho, $50 \%$ dos esporos germinaram 10 horas após a inoculação (Figura 7a). Com 13 horas de incubação, essa porcentagem subiu para 95\%. Ainda neste tempo, os conídios apresentaram considerável elongação dos tubos germinativos (Figura $7 \mathrm{~b}$ ), muitos dos quais mostraram ramificações laterais ou terminais, provavelmente produzidas para aumentar as chances de localização de sítios infectivos. Também foi observada a presença de pequenas estruturas semelhantes a apressórios ao longo dos tubos germinativos (Figuras 7c e 7d). Estas estruturas provavelmente estão associadas a fixação do mesmos à superfície do hospedeiro.

Com 16 horas após a inoculação, longos tubos germinativos foram observados em toda a superfície do tecido foliar. Um grande número de tubos germinativos apresentou crescimento direcionado aos estômatos (Figura 7e). Neste período, hifas infectivas de dois esporos mostraram-se inseridas dentro de estômatos da hospedeira (Figuras $8 \mathrm{a}$ e $8 \mathrm{~b}$ ). Isso representa $4 \%$ do total de esporos observados, mostrando que na presença de hospedeira suscetível e sob condições ideais de temperatura e umidade, a penetração pode ter início 16 horas após o contato com o tecido foliar. 


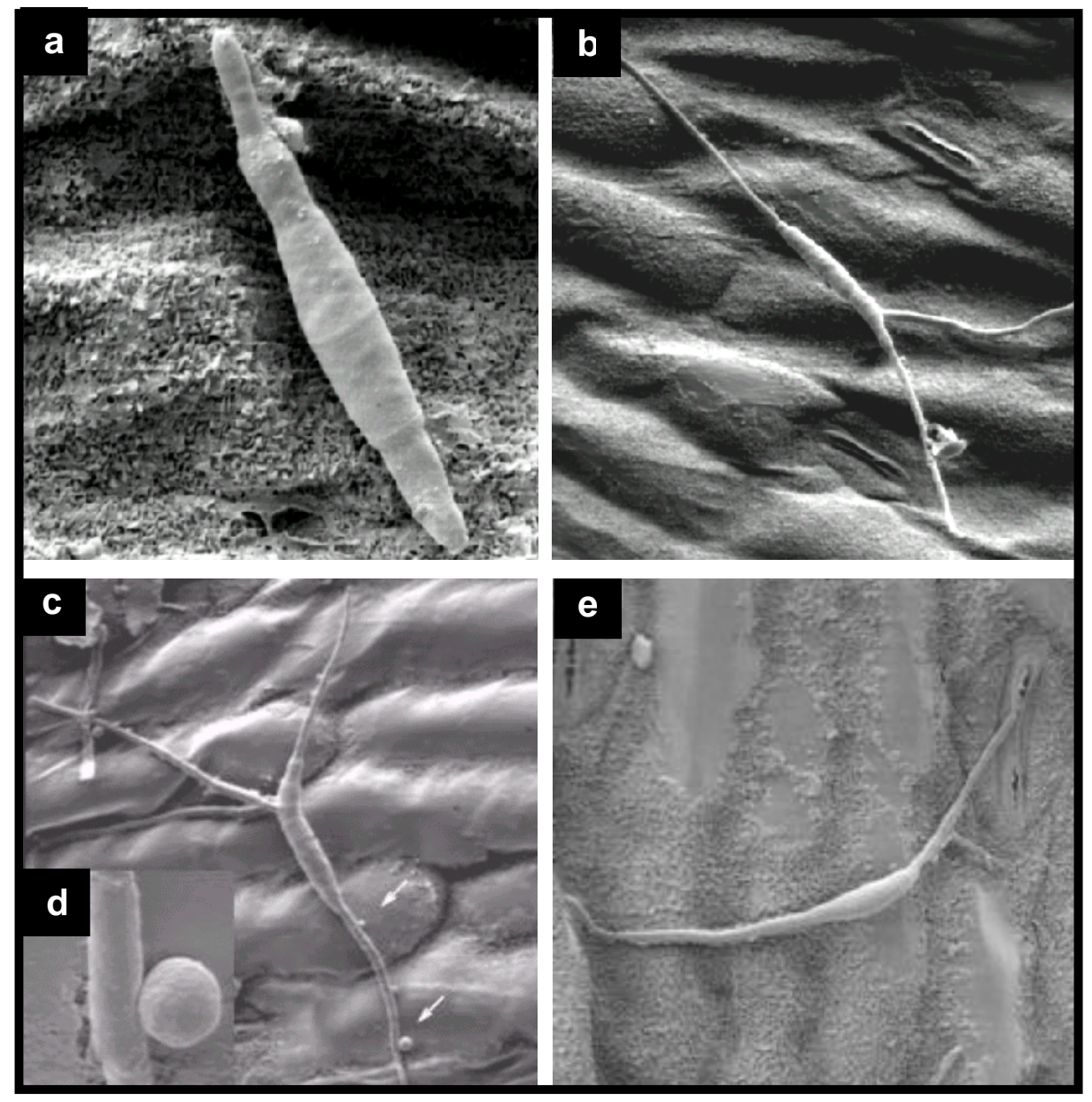

Figura 7 - Microscopia eletrônica de varredura da fase de pré-penetração de $C$. zeae-maydis em folhas do híbrido de milho suscetível DAS-8432: a) germinação conidial ocorrida 10 horas após a inoculação (aumento 2000x); b) elongação do tubo germinativo às 13 horas da inoculação (aumento 1000x); c) formação de estruturas similares a apressórios (seta) (aumento 750x), 13 horas após inoculação; d) detalhe destas estruturas (aumento 10.000x); e) Com 16 horas após a inoculação os tubos germinativos mostravam seu direcionamento em direção aos estômatos (aumento 1000x) 


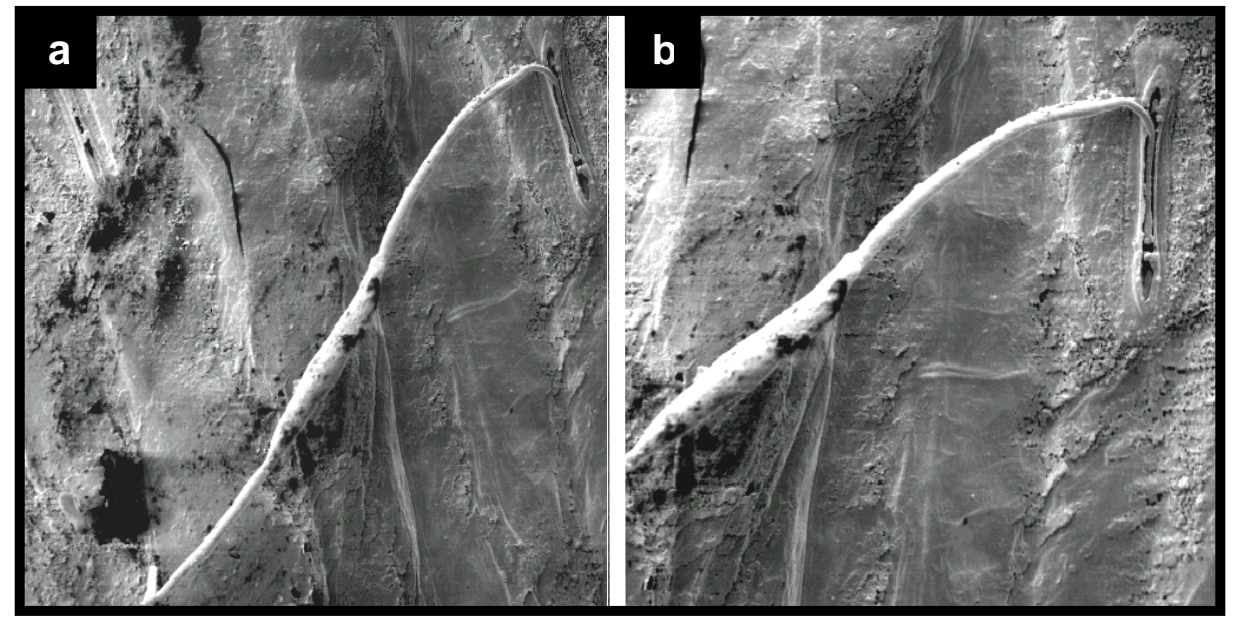

Figura 8 - a) Penetração via estômato de C. zeae-maydis no híbrido de milho suscetível DAS-8432 às 16 horas após a inoculação (aumento 1000x); b) detalhe (aumento 3000x)

\subsubsection{Conidiação microcíclica em isolados de C. zeae-maydis}

Todos os 64 isolados produziram grande quantidade de conídios hialinos e obclavados, típicos de C. zeae-maydis. Onze isolados apresentaram conidiação microcíclica (Figura 9), todos eles pertencentes ao grupo I. Isso representa $26 \%$ dos isolados deste grupo. Nenhum isolado do grupo II mostrou formação de estruturas típicas deste fenômeno. Sob microscopia de luz, foi possível verificar a produção de esporos secundários em células centrais e terminais dos conídios de C. zeae-maydis (Figura 10), demonstrando a capacidade de alguns isolados em produzir grande quantidade destes esporos. Na Figura 11 é possível visualizar, através da MEV, a presença do conídio primário, o conidióforo e a cicatriz deixada pelo conídio secundário. 


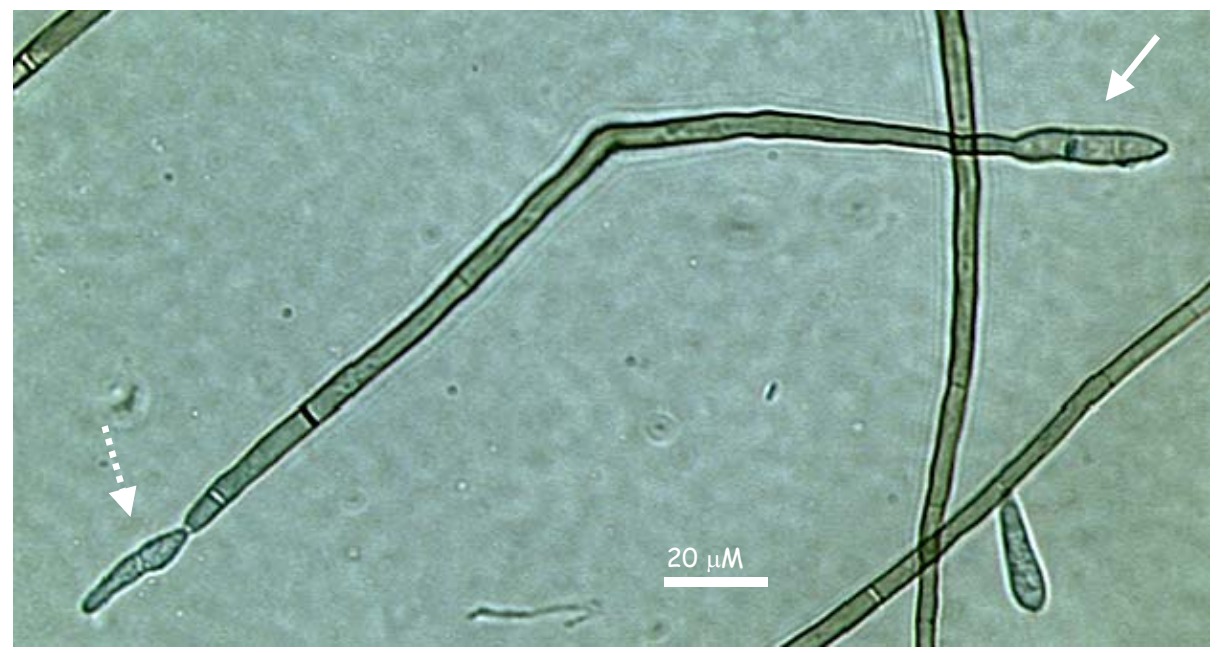

Figura 9 - Conidiação microcíclica em isolado do grupo I de C. zeae-maydis. Note, na seta cheia, o conídio primário; na pontilhada o secundário e, unindo os dois, o conidiofóro. Microscopia de luz - aumento 400x

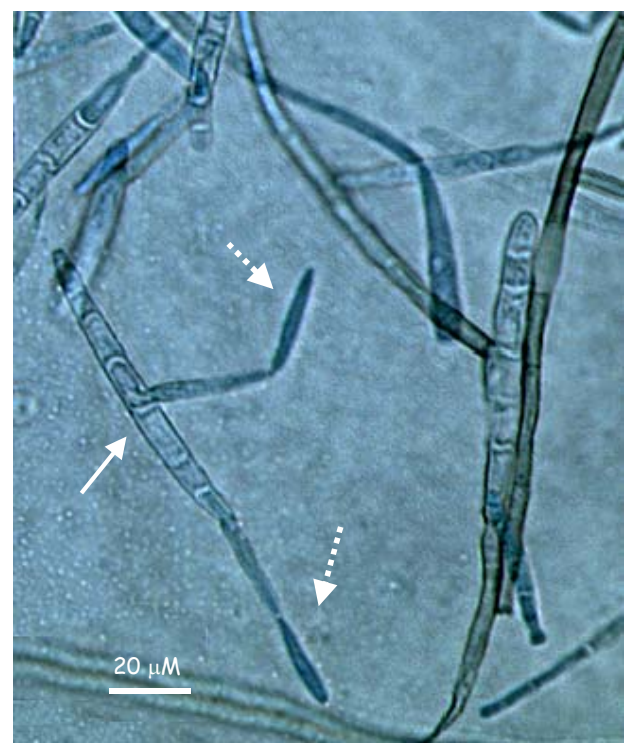

Figura 10 - Conidiação microciclica ocorrendo na célula central e terminal do conídio primário. Na seta cheia observa-se o conídio primário e nas pontilhadas os secundários. Microscopia de luz - aumento $400 x$ 


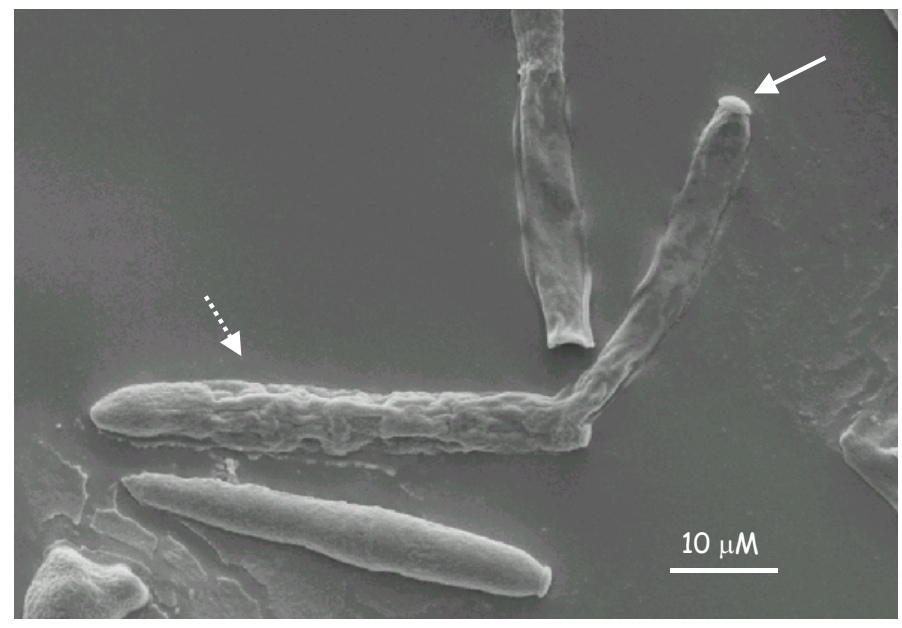

Figura 11 - Microscopia eletrônica de varredura. Note na seta pontilhada o conídio primário e na seta cheia a cicatriz no conidióforo onde esteve preso o conídio secundário

\subsection{Discussão}

Analisando os processos de pré-penetração nos tecidos foliares de milho por C. zeae-maydis, verificou-se que estes foram similares àqueles reportados para outras espécies do gênero Cercospora (Rathaiah, 1977; Beckman \& Payne, 1982). Neste estudo, foi possível observar que 95\% dos esporos germinaram até 13 horas após o contado destes com a superfície da hospedeira, dados corroborados pelos estudos de Beckman \& Payne (1982) que relataram período médio de germinação em torno de 12 horas para um isolado de C. zeae-maydis. A ramificação do tubo germinativo e o extenso crescimento vegetativo na superfície da hospedeira, observado claramente às 16 horas após a inoculação (Figura 6e), indicaram o tropismo do fungo em direção aos estômatos. Este vigoroso crescimento também pode ter sido induzido pela presença do filme de água formado na folha por ocasião da 
inoculação. Beckman \& Payne (1982) relatam que C. zeae-maydis necessita de umidade relativa do ar próxima de 98\% para que a infecção ocorra, mas a presença de água livre na superfície foliar pode diminuir a capacidade do fungo em localizar os estômatos, fazendo com que os tubos germinativos tornem-se mais alongados. Se durante o crescimento do tubo germinativo o filme d'água for removido, o tropismo volta a ser eficiente e a localização dos estômatos favorecida. Neste trabalho, foi possível verificar água livre na folha até 13 horas após a inoculação. Sendo assim, o fungo foi induzido a alongar o tubo germinativo logo após a germinação, encontrando em seguida condições ideais para a busca de sítios de penetração.

Muitas estruturas similares a apressórios foram observadas 13 horas após a inoculação (Figuras $6 c$ e $6 \mathrm{~d}$ ). O processo de penetração através dos estômatos foi observado 16 horas após a inoculação. Não houve indícios de penetração direta através da superfície intacta da folha, assim como já observado para várias espécies de Cercospora (Rathaiah, 1976; Whitney \& Duffus, 1986), incluindo C. zeae-maydis (Beckman \& Payne, 1982; Ward et al., 1999). Beckman \& Payne (1982) encontraram os primeiros indícios de penetração, via estômato, com 24 horas de incubação em ambiente com umidade relativa próximo à saturação. A diferença pode ser devida a diferenças de temperatura, da suscetibilidade da hospedeira, ou da agressividade dos isolados entre os experimentos. Quatro porcento dos esporos examinados haviam alcançado os estômatos 16 horas após a inoculação. Presume-se que as condições ambientais devem permanecer favoráveis por um longo período de tempo para que ocorra a infecção, como temperatura ao redor de $30^{\circ} \mathrm{C}$ e principalmente alta umidade relativa do ar. Testes realizados em genótipos suscetíveis de milho para determinação da patogenicidade de alguns isolados (Brunelli, KR, dados não publicados) indicaram que a manutenção por 36 horas de câmara úmida, após a inoculação, foi necessária para que o fungo causasse doença. Estes dados corroboram as observações a campo, onde a maior incidência da doença ocorre em regiões quentes e altas, nas quais há 
prevalência de orvalho nas primeiras horas da manhã ou em períodos do ano em que se verifica grande número de dias nublados.

Para muitos fungos, uma forma alternativa de sobrevivência no campo durante períodos de estresse ambiental ou nutricional se dá através do fenômeno conhecido como conidiação microcíclica. Geralmente estresse físico ou nutricional induzem o fenômeno (Anderson \& Smith, 1971). Neste trabalho, a conidiação microcíclica foi verificada oito dias após a transferência de conídios de C. zeae-maydis para meio de cultura V8 sob temperatura de $27^{\circ} \mathrm{C}$. Lapaire \& Dunkle (2003) também verificaram a produção deste fenômeno quando cultivaram conídios deste fungo a $25^{\circ} \mathrm{C}$ em diferentes substratos. Temperaturas na faixa de 25 a $28^{\circ} \mathrm{C}$ são tidas como ideais tanto para o crescimento vegetativo de C. zeae-maydis quanto para a sua reprodução (Ward et al, 1999; Laterell \& Rossi, 1983), não representando estresse físico ao patógeno. Uma vez que esporos secundários foram produzidos em temperaturas na faixa da ideal para o fungo, é possível inferir que a temperatura não foi a responsável pela indução da conidiação microcíclica. Já quanto ao meio de cultura, o meio V8 é reconhecido como um dos melhores substratos para esporulação nesta espécie de Cercospora (Capítulo 3), sendo também um meio adequado ao crescimento vegetativo. Isso sugere que $C$. zeae-maydis pode produzir esporos secundários sem a presença de fatores físicos ou nutricionais estressantes.

Para as condições utilizadas neste experimento, não foi verificada a conidiação microcíclica em nenhum isolado pertencente ao grupo II de C. zeaemaydis. Isso pode ser devido a diferenças genéticas já relatada entre estes dois grupos (Wang et al., 1998; Dunkle \& Levy, 2000). Este é o primeiro relato da presença deste fenômeno no grupo I e ausência no grupo II, sendo mais uma evidência da divisão da espécie C. zeae-maydis em duas espécies afins (sibling species).

Lapaire \& Dunkle (2003) encontraram considerável produção de conídios secundários quando inocularam esporos de C. zeae-maydis em tricomas de soja. Nas áreas brasileiras de cultivos de grãos, é comum a rotação da cultura 
de milho com a da soja, sob semeadura direta na palhada. Assim, os conídios primários podem ser dispersos dos resíduos do milho para tricomas da soja ou até mesmo de outras espécies cultivadas ou invasoras. Depois de consecutivos ciclos de conidiação microcíclica nos tricomas, os conídios secundários podem ser dispersos para a superfície de plantas de milho de campos vizinhos. Encontrando condições ambientais e nutricionais adequadas, tanto os conídios primários quanto aqueles resultantes da conidiação microcíclica podem germinar, penetrar e colonizar sua hospedeira. Desta forma, este fenômeno representa uma alternativa de permanência do inóculo na área, mesmo sem a presença de seu hospedeiro.

\subsection{Conclusões}

1. Sob condições ambientais favoráveis e hospedeiro suscetível, C. zeae-maydis requer cerca de 13 horas para que 95\% dos esporos depositados sobre a hospedeira germinem e 16 horas para iniciar a infecção.

2. O processo de microconidiação foi observado apenas em isolados do grupo I de C. zeae-maydis. 


\section{AGRESSIVIDADE DE ISOLADOS DE Cercospora zeae-maydis A LINHAGENS DE MILHO.}

\section{Resumo}

Inoculações artificiais são comumente usadas para selecionar genótipos de milho resistentes a patógenos. Este trabalho teve por objetivo avaliar a agressividade de três isolados de C. zeae-maydis, agente causal da mancha de cercospora, em quatro linhagens homozigotas de milho. Os isolados utilizados são provenientes de Cristalina-GO, Indianópolis-MG e Guaíra-SP. O experimento foi conduzido em casa de vegetação no delineamento de blocos ao acaso com tratamentos dispostos em esquema fatorial 3 (isolados) $\times 4$ (linhagens), com quatro repetições. A unidade experimental foi composta por um vaso com quatro plantas. A inoculação foi realizada quando as plantas apresentavam seis folhas completamente expandidas, através da adição de quatro sementes de sorgo colonizadas pelo patógeno no cartucho e aspersão de uma suspensão de $4 \times 10^{4}$ conídios $/ \mathrm{mL}$. Após a inoculação, as plantas permaneceram sob câmara úmida durante 48 horas. A avaliação dos sintomas foi realizada na folha inoculada, 35 dias após a inoculação, através de escala de notas que variou de 1 - folha sem doença a 4 - folha com mais de 20 lesões cloróticas estriadas, sendo algumas esporulantes. Houve diferenças significativas em resistência das linhagens e agressividade dos isolados. Os isolados de Cristalina e Indianópolis, ambos com nota média de severidade de 
1,94, foram os mais agressivos. Não houve interação entre isolado e linhagem a $1 \%$ de probabilidade pelo teste $\mathrm{F}$.

\section{Aggressiveness of cercospora zeae-maydis isolates in maize lines.}

\section{Summary}

Artificial inoculation are commonly used to select genotypes of maize resistant to pathogens. This work evaluated disease symptoms of three different isolates of C. zeae-maydis, the causal agent of gray leaf spot, in four distinct lines of maize lines. The isolates were collect in Cristalina-GO (Cris-3), Indianópolis-MG (I-5), and Guaíra-SP (Gua-5). The trial was carried out in a greenhouse under a randomized blocks experimental design with treatments arranged as a 3 (isolate) $\times 4$ (lines) factorial scheme with four replicates. The experimental unit consisted of one vase with four plants. Plants with six expanded leaves were inoculated in the worhl with four sorghum seeds colonized with the pathogen and also in the leaves by spraying a spore suspension of $4 \times 10^{4}$ conidia/mL. Plants were maintained in conditions of high humidity for 48 hours to guarantee infection and penetration. Disease symptoms were evaluate in leaves, 35 days after the inoculation, with a diagrammatic scale (1 - leaf with no symptoms to 4 - leaf with more 20 clorotical lesions and sporulating in some cases). Significant differences in aggressiveness of isolates and in the degree of resistance of hibrid lines were detected. Isolates Cris-3 e I5 were the most agressive, with an average of 1.94 using the diagrammatic scale. No significant interaction between isolate $\mathrm{x}$ lines was observed in test $\mathrm{F}$. 


\subsection{Introdução}

A mancha de cercospora é considerada uma das mais importantes doenças foliares do milho em várias regiões do mundo onde este cereal é cultivado. No Brasil, esta mancha foi relatada pela primeira vez em 1953 (Chupp, 1953), mas só se tornou importante a partir de 2000 (Fantin et al., 2001). O aumento de incidência e severidade desta doença tem sido associado à continuidade temporal do plantio, a adoção do plantio direto, e a utilização de irrigação via pivô-central, que garantem ambiente ideal para aumento e manutenção do inóculo (Latterel \& Rossi,1983; Payne \& Waldron , 1983; Payne et al. ,1987) .

Esta doença é causada pelo fungo imperfeito Cercospora zeae-maydis Tehon \& Daniels. Uma outra espécie, C. sorghi f. sp. maydis, também pode ser encontrada nas lesões características da doença, mas colonizando com menor eficiência os tecidos foliares do milho (Chupp, 1953; Latterell \& Rossi, 1983; Ward et al., 1999). Em estudos recentes, foi demonstrado que a população de C. zeae-maydis é composta por dois grupos geneticamente distintos, mas morfologicamente semelhantes (Carson, et al., 1997; Wang et al., 1998; Dunkle \& Levy, 2000). Variabilidade em agressividade, taxas de crescimento em meio de cultura e morfologia da colônia também têm sido descritos para esta espécie (Latterel \& Rossi, 1983, Dunkle \& Carson, 1998). Entretanto, nenhuma destas evidências têm sido suficientes para separar os isolados em raças fisiológicas, como confirmam os trabalhos realizados por Bayers \& Ayers (1986).

Embora a mancha de cercospora possa ser controlada quimicamente (Munkvold et al., 2001), a resistência genética é a principal medida de controle para esta doença no Brasil. Genes de resistência foram descritos em germoplasma tropical e temperado (Donahue et al., 1991; Bubeck et al., 1993; Coates \& White, 1998; Clements et al., 2000) e incorporados a híbridos comerciais. Entretanto, um problema enfrentado de maneira recorrente pelos melhoristas ,é mudança de comportamento de resistência dos híbridos, tanto ao 
longo dos anos quanto entre as áreas de cultivo (Carson et al., 2002; Bubeck et al., 1993). Esse comportamento pode estar relacionado, em parte, à diferenças em agressividade dos isolados presentes nos diferentes ambientes. Assim, Dunkle \& Carson (1998) e Carson et al. (2002) sugerem a seleção e utilização de isolados mais agressivos do patógeno em programas de seleção de genótipos superiores para resistência, na tentativa de minimizar a interação entre genótipo e ambiente. Diante disto, o objetivo deste trabalho foi verificar a agressividade de três isolados geneticamente distintos de C. zeae-maydis (Capítulo 5) em quatro linhagens homozigotas de milho.

\subsection{Material e Métodos}

Os isolados utilizados são provenientes de Cristalina-GO (Cris-3), Indianópolis-MG (I-5) e Guaíra-SP (Gua-5). Estes foram previamente classificados como geneticamente divergentes com base em estudos com marcadores AFLP e análise de restrição da região ITS do rDNA (Capítulo 5). Através deste último método, os mesmos foram separados de acordo com os grupos genéticos descritos para esta espécie (Wang et al., 1998). Gua-5 e I-5 pertencem ao Grupo I, enquanto Cris-3 ao Grupo II. A produção de inóculo foi realizada de duas formas: meio de cultura e sementes de sorgo. Para a esporulação em meio de cultura, os isolados foram cultivado em meio V8, sob fotoperíodo de 12 horas por oito dias a temperatura de $27^{\circ} \mathrm{C}$ (Capítulo 3). Para a esporulação em sementes de sorgo, os isolados foram repicados para erlenmeyers contendo sementes de sorgo/água na proporção 100/85 (p/v), previamente tindalizadas.

As linhagens de milho pertencem a programas de melhoramento da ESALQ-USP (ELQ-28); UFG (UFG-89) e UFLA (GNS-61, GNS-76) e foram gentilmente cedidas para a realização deste trabalho. Em experimentos anteriores realizados em dois ambientes distintos (Capítulo 4), estas 
demonstraram alta interação genótipo $\mathrm{x}$ ambiente, tendo comportamentos discrepantes quanto a resistência nos dois locais.

O experimento foi conduzido em casa de vegetação no delineamento de blocos ao acaso com tratamentos dispostos em esquema fatorial 3 (isolados) $\mathrm{x}$ 4 (linhagens), com quatro repetições. A unidade experimental foi composta por um vaso com quatro plantas. A inoculação foi realizada quando as plantas apresentavam seis folhas completamente expandidas, através da adição de quatro sementes de sorgo colonizadas pelo patógeno no cartucho e aspersão de uma suspensão de $4 \times 10^{4}$ esporos $/ \mathrm{mL}$. As folhas que receberam o sorgo e a aspersão de esporos foram identificadas no momento da inoculação. As plantas permaneceram sob câmara úmida durante 48 horas para garantir a germinação dos esporos e a penetração na hospedeira. Os sintomas foram avaliados na folha inoculada, 35 dias após a inoculação, através de escala de notas que variou de 1 a 4 , onde 1 - folha sem sintoma; 2 - folha com menos de 10 pontuações cloróticas; 3 - folha com mais de 10 lesões cloróticas e estriadas, algumas com pontos de esporulação e 4 - folha com mais de 20 lesões cloróticas e estriadas, algumas esporulantes (Figura 12). 


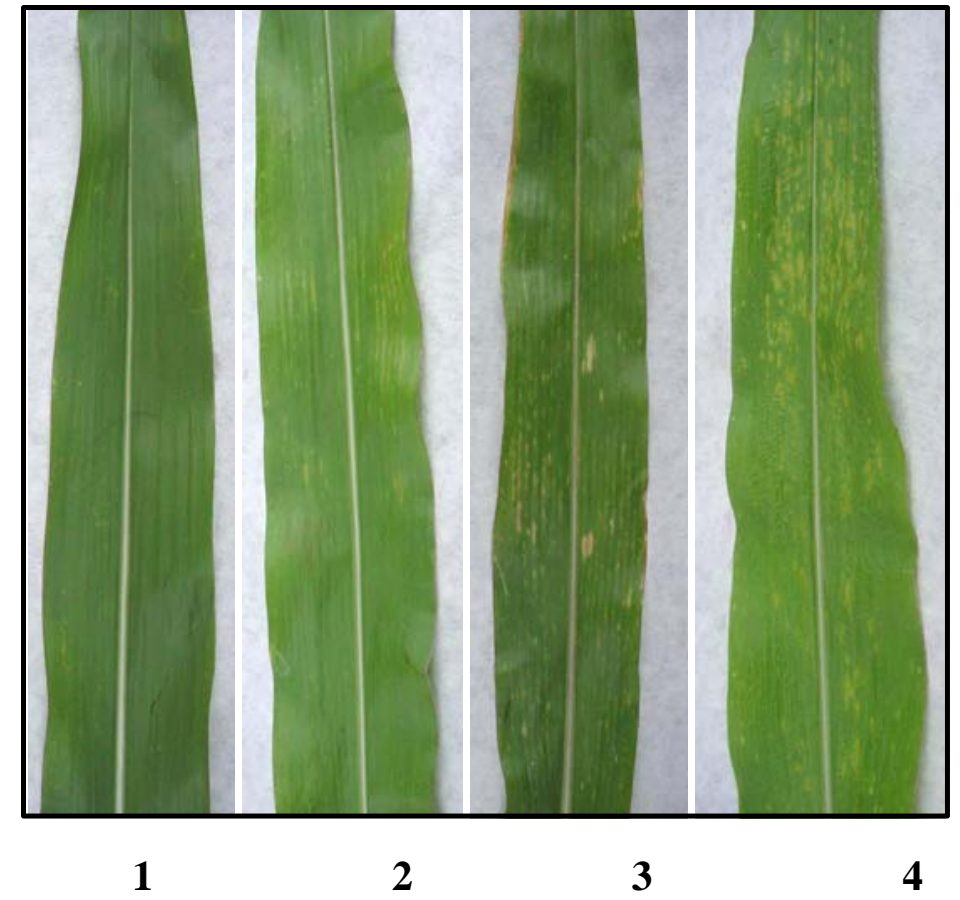

Figura 12 - Escala diagramática utilizada para avaliação dos níveis da mancha de cercospora nas linhagens de milho. 1 - sem sintoma; 2 - menos de 10 pontuações cloróticas; 3 - mais de 10 lesões cloróticas e estriadas, algumas com pontos de esporulação; 4 - mais de 20 lesões cloróticas e estriadas, algumas esporulantes

Os resultados foram submetidos a ANOVA para averiguação de diferenças de agressividade entre isolados e/ou interação entre isolado $x$ linhagem, seguido de teste Tukey de comparação múltipla de médias. As análises foram realizadas com o auxílio do programa estatístico SAS (versão 8,0 - SAS Institute, Cary, NC). 


\subsection{Resultados e Discussão}

Durante a condução do experimento foi possível observar a ocorrência de sintomas típicos da doença em todas as parcelas do experimento, demonstrando que a inoculação foi eficiente e que o ambiente foi propício à infecção e colonização do fungo na hospedeira. Foi possível verificar diferenças significativas quanto a suscetibilidade/resistência das linhagens e agressividade dos isolados (Tabela 9). Quanto às linhagens, estas demonstraram diferentes níveis de resistência, corroborando dados anteriores (Capítulo 4). GNS-61 e UFG-89 foram as mais resistentes, com notas médias de 1,18 e 1,42, respectivamente, enquanto ELQ-28 foi a mais suscetível, com média 2,58. Isso demonstra a existência de variabilidade genética para resistência entre os genótipos testados (Tabela 10).

Tabela 9. Resumo da análise de variância da avaliação de agressividade de três isolados de $C$. zeae-maydis em quatro linhagens de milho

\begin{tabular}{lcrll}
\hline \multicolumn{1}{c}{ Fonte de variação } & G.L. & S.Q. & Q.M. & F \\
\hline Isolado & 2 & 2,503 & 1,25 & $6,71^{\text {** }}$ \\
Linhagem & 3 & 13,764 & 4,588 & $24,59^{* *}$ \\
Repetição (bloco) & 3 & 0,514 & 0,171 & $0,92^{\mathrm{ns}}$ \\
Isolado vs Linhagem & 6 & 4,216 & 1,251 & $3,77^{\mathrm{ns}}$ \\
Resíduo & 33 & 6,157 & 0,186 & \\
\hline Total & 47 & & \\
${ }^{n \text { ns }}$ não significativo e " significativo a 1\% de probabilidade &
\end{tabular}


Tabela 10. Severidade da mancha de cercospora nas quatro linhagens de milho causada por três isolados de $C$. zeae-maydis, medida através de escala de notas de severidade de 1 (sem sintoma) a 4 (mais de 20 lesões cloróticas e estriadas, algumas esporulantes)

\begin{tabular}{|c|c|c|c|c|}
\hline \multirow[b]{2}{*}{ Linhagem ${ }^{*}$} & \multicolumn{4}{|c|}{ Isolado* } \\
\hline & Cris-3 & $1-5$ & Gua-5 & Média $^{* *}$ \\
\hline ESALQ-28 & 2,94 & 3,25 & 1,56 & $2,58 \mathrm{a}$ \\
\hline GNS-76 & 2,00 & 1,87 & 1,87 & $1,92 \mathrm{~b}$ \\
\hline UFG-89 & 1,56 & 1,44 & 1,25 & $1,42 \mathrm{c}$ \\
\hline GNS-61 & 1,25 & 1,18 & 1,12 & $1,18 \mathrm{c}$ \\
\hline Média ${ }^{* *}$ & $1,94 \mathrm{~A}$ & $1,94 \mathrm{~A}$ & $1,45 \mathrm{~B}$ & \\
\hline
\end{tabular}

Para a análise da agressividade entre isolados, aqueles provenientes da região de Cristalina (Cris-3) e de Indianópolis (I-5) foram mais agressivos que o de Guaíra (Gua-5). I-5 e Gua-5 pertencem ao grupo I de C. zeae-maydis, ao passo que Cris-3 ao grupos II. Vanderplank (1984) descreve agressividade como sendo a capacidade diferencial dos isolados em causar doença num mesmo cultivar ou em um grupo deste. Assim, um isolado representante do grupo I e outro do grupo II foram estatisticamente iguais quanto a maior capacidade em causar doença nas linhagens de milho, enquanto um outro do grupo I foi menos agressivo. Estes resultados contrastam com os dados obtidos por Carson et al. (2002), um isolado representante do grupo II foi o menos agressivo de um total de seis isolados testados. Comparando os resultados do estudo de Carson et al. (2002) com aqueles aqui obtidos, verifica-se que a diferença de agressividade encontrada entre os isolados de C. zeae-maydis 
parece não estar relacionada aos grupos genéticos, assim como sugerido por Dunkle \& Carson (1999). Os isolados mais agressivos deste estudo (Cris-3 e I5) provieram de regiões com altas incidência e severidade da mancha, ao passo que o menos agressivo (Gua-5) foi coletado em área com moderada severidade da doença. Esta observação pode indicar que a maior severidade observada nas áreas de Cristalina e Indianópolis pode ser devido a uma associação entre ambiente altamente favorável para o estabelecimento do patógeno e maior agressividade dos isolados presentes nestas regiões. Porém, novos estudos com um número maior de isolados são necessários para comprovar tal observação. Este trabalho é o primeiro relato da existência de diferenças em agressividades entre isolados brasileiros de C. zeae-maydis.

Não houve interação significativa entre isolados vs. linhagens em nível de 1\% de significância pelo teste $\mathrm{F}$ (Tabela 9), fato já observado em outros. Carson et al. (2002) verificaram interação significativa entre híbridos vs. isolados, mas como os ensaios foram realizados a campo, os autores sugerem que esta significância seja mais uma conseqüência das interações entre híbrido vs. locais do que especializações do patógeno. Deste modo, assim como ocorreu em outros trabalhos, não foi possível comprovar a existência de raças fisiológicas de C. zeae-maydis.

Finalmente, Carson et al. (2002) afirmam que a agressividade de C. zeae-maydis é um caracter com alta reproducibilidade e de fácil seleção. Assim, os programas de melhoramento devem expor seus genótipos a isolados mais agressivos e em ambientes favoráveis ao estabelecimento da doença para, desta forma, produzirem híbridos com níveis satisfatórios e duráveis de resistência a esta importante doença. 


\subsection{Conclusões}

1. Foi possível verificar diferenças significativas em agressividade entre isolados brasileiros, sendo este o primeiro relato de tal fato.

2. A agressividade observada entre os isolados não foi relacionada aos grupos genéticos a que estes pertencem, mas ao local de coleta dos mesmos. 


\section{CONCLUSÕES GERAIS}

1. As melhores taxas de esporulação foram conseguidas quando o fungo C. zeae-maydis foi submetido aos meios de cultura V8 e STT (suco de tomate temperado) sob fotoperíodo 12/12 h (luz/escuro).

2. No estudo de reação de genótipos de milho a doença, foi possível verificar interação significativa entre genótipo e ambiente, indicando que fatores ambientais ou patogênicos atuam nestes ambientes influenciando o comportamento dos genótipos. Doze linhagens apresentaram alta resistência a doença em ambos os ambientes testados, indicando a possibilidade de utilização dos seus genes de resistência em programas de melhoramento genético da cultura.

3. Uma única avaliação da doença no estádio fenológico sete (milho verde) é suficiente para determinar a resistência/suscetibilidade dos genótipos de milho a este patógeno.

4. A composição genética da população brasileira de C. zeaemaydis é semelhante àquelas encontradas nos Estados Unidos e na África, sendo composta pelos dois grupos genéticos (I e II) já descritos para a espécie. Foi verdificada alta similaridade genética dentro de cada agrupamento, tanto entre os isolados brasileiros, quanto entre estes e os americanos e africanos 
(utilizados para efeitos comparativos), evidenciando a baixa diversidade genética do fungo.

5. Sob condições ambientais favoráveis, C. zeae-maydis inicia seu processo de infecção com 16 horas após a deposição de estruturas reprodutivas na superfície hospedeira.

6. O fenômeno da conidiação microcíclica está apresente apenas em isolados do grupo I, estando ausente naqueles do grupo II.

7. A agressividade do patógeno não está relacionada ao grupo genético a que pertence, mas a região de coleta dos isolados. Em áreas onde a doença se mostra mais severa, encontram-se os isolados mais agressivos, independentemente do grupo a que pertencem. 


\section{ANEXOS}


Tabela 2. Linhagens de milho utilizadas no estudo de reação de resistência à C. zeae-maydis, suas denominações originais e respectivas bases genéticas

\begin{tabular}{|c|c|c|}
\hline $\begin{array}{c}\text { Denominação/ } \\
\text { trabalho }\end{array}$ & Denominação original & Base genética \\
\hline ESALQ1 & 16-2-S6 16-02D & Tropical \\
\hline ESALQ2 & 16-2-S6 25-04D & Tropical \\
\hline ESALQ3 & 16-2-S6 27-01D & Tropical \\
\hline ESALQ4 & 16-2-S6 39-05D & Tropical \\
\hline ESALQ5 & 16-2-S6 55-02D & Tropical \\
\hline ESALQ6 & $16-2-S 6$ 66-08D & Tropical \\
\hline ESALQ7 & 16-2-S6 94-02D & Tropical \\
\hline ESALQ8 & 16-2-S6 102-02D & Tropical \\
\hline ESALQ9 & 16-2-S6 120-04D & Tropical \\
\hline ESALQ10 & 16-2-S6 149-05D & Tropical \\
\hline ESALQ11 & 16-2-S6 168D & Tropical \\
\hline ESALQ12 & L04 HS1 S6 03-01D & Tropical \\
\hline ESALQ13 & L04 HS1 S6 2002R & Tropical \\
\hline ESALQ14 & L04 HS1 S6 3007F & Tropical \\
\hline ESALQ15 & L04 HS1 S6 3101F & Tropical \\
\hline ESALQ16 & L04 HS1 S6 3304D & Tropical \\
\hline ESALQ17 & L04 HS1 S6 3607F & Tropical \\
\hline ESALQ18 & I6-1-S7 0405F & Tropical \\
\hline ESALQ19 & I6-1-S7 0805F & Tropical \\
\hline ESALQ20 & I6-1-S7 8805F & Tropical \\
\hline ESALQ21 & I6-1-S7 9005F & Tropical \\
\hline ESALQ22 & L06XL 560 S6-08F & Tropical \\
\hline ESALQ24 & 1404 & Tropical \\
\hline ESALQ25 & L06XL 560 S6 56D & Tropical \\
\hline ESALQ26 & L06XL 560 S6 128D & Tropical \\
\hline ESALQ27 & Top cross S5 14-01F & Tropical \\
\hline ESALQ28 & Top cross S5 45-03D & Tropical \\
\hline ESALQ29 & Top cross S5 49-02D & Tropical \\
\hline ESALQ30 & Top cross S5 53-01F & Tropical \\
\hline ESALQ31 & Top cross S5 82-01D & Tropical \\
\hline ESALQ32 & Top cross S5 13-01F & Tropical \\
\hline ESALQ33 & Top cross S5 148-03F & Tropical \\
\hline ESALQ34 & L03 BR201-S6-1604R & Tropical \\
\hline ESALQ35 & L03 BR201-S6-1607F & Tropical \\
\hline ESALQ36 & L03 BR201-S6-2202D & Tropical \\
\hline ESALQ37 & L03 BR201-S6-2305D & Tropical \\
\hline ESALQ38 & L03 BR201-S6-2403R & Tropical \\
\hline ESALQ39 & L03 BR201-S6-2903D & Tropical \\
\hline ESALQ40 & L03 BR201-S6-3504F & Tropical \\
\hline ESALQ41 & L03 BR201-S6-4401F & Tropical \\
\hline ESALQ42 & L03 BR201-S6-4610D & Tropical \\
\hline ESALQ43 & L03 BR201-S6-4803D & Tropical \\
\hline
\end{tabular}


Tabela 2. Linhagens de milho utilizadas no estudo de reação de resistência à C. zeae-maydis, suas denominações originais e respectivas bases genéticas

\begin{tabular}{|c|c|c|}
\hline $\begin{array}{c}\text { Denominação/ } \\
\text { trabalho }\end{array}$ & Denominação original & Base genética \\
\hline ESALQ44 & CMS 05 S6 18-08AF & Tropical \\
\hline ESALQ45 & CMS 05 S6 37-02BD & Tropical \\
\hline ESALQ46 & CMS 05 S6 37-03BF & Tropical \\
\hline ESALQ47 & CMS 05 S6 37-04BF & Tropical \\
\hline ESALQ48 & CMS 05 S6 37-07BD & Tropical \\
\hline ESALQ49 & L05-606-S6-31F & Tropical \\
\hline ESALQ50 & L05-606-S6-53F & Tropical \\
\hline ESALQ51 & L02-601-S6 06-05D & Tropical \\
\hline ESALQ52 & Top cross S5 61-02F & Tropical \\
\hline ESALQ53 & Top cross S5 8403F & Tropical \\
\hline ESALQ54 & CHS 05 S5 0804BD & Tropical \\
\hline GNS55 & PopGNS3-24-1 & Tropical/subtropical \\
\hline GNS56 & PopGNS3-62-1 & Tropical/subtropical \\
\hline GNS57 & PopGNS3-92-1 & Tropical/subtropical \\
\hline GNS58 & GNS3-107-1 & Tropical/subtropical \\
\hline GNS59 & GNS1-398-1 & Tropical \\
\hline GNS60 & GNS1-435-1 & Tropical \\
\hline GNS61 & 559-1 GNS1 & Tropical \\
\hline GNS62 & GNS1-545-1 & Tropical \\
\hline GNS63 & GNS1-579-1 & Tropical \\
\hline GNS64 & GNS1-761-1 & Tropical \\
\hline GNS65 & GNS6206-1264-1 & Temperado \\
\hline GNS66 & $6206-1222-1$ & Temperado \\
\hline GNS68 & GNS10-280-1 & Tropical \\
\hline GNS69 & GNS10-262-1 & Tropical \\
\hline GNS70 & GNS10-323-1 & Tropical \\
\hline GNS71 & GNS10-369-1 & Tropical \\
\hline GNS72 & GNS6-1064-1 & Tropical \\
\hline GNS73 & GNS6-1058-1 & Tropical \\
\hline GNS74 & GNS5-999-1 & Tropical \\
\hline GNS75 & GNS5-1012-1 & Tropical \\
\hline GNS76 & GNS5-1035-1 & Tropical \\
\hline GNS77 & GNS9-1178-1 & Tropical \\
\hline GNS78 & GNS9-1183-1 & Tropical \\
\hline GNS79 & GNS7-1109-1 & Subtropical \\
\hline GNS80 & GNS7-1074-1 & Subtropical \\
\hline GNS81 & GNS8-1127-1 & Tropical/subtropical \\
\hline GNS82 & GNS8-1137-1 & Tropical/subtropical \\
\hline GNS83 & GNS4-941-1 & Tropical/subtropical \\
\hline GNS85 & GNS4-920-1 & Tropical/subtropical \\
\hline
\end{tabular}


Tabela 2. Linhagens de milho utilizadas no estudo de reação de resistência à C. zeae-maydis, suas denominações originais e respectivas bases genéticas

\begin{tabular}{|c|c|c|}
\hline $\begin{array}{c}\text { Denominação/ } \\
\text { trabalho }\end{array}$ & Denominação original & Base genética \\
\hline UFG86 & 43.493 & Mista - predominância de temperado \\
\hline UFG87 & 42.276 & Mista - predominância de temperado \\
\hline UFG88 & 45.244 & Mista com predominância de tropical \\
\hline UFG89 & 18.104 & Tropical (BR 105 Flint do caribe) \\
\hline UFG90 & 45.262 & Mista - predominância de tropical \\
\hline UFG91 & 42.276 & Mista - predominância de temperado \\
\hline UFG92 & 19.124 & Tropical (BR 106 Tuxpeño) \\
\hline UFG93 & 40.422 & Mista com predominância de tropical \\
\hline UFG94 & 43.429 & Mista - predominância de temperado \\
\hline UFG95 & 45.105 & Mista - predominância de tropical \\
\hline UFG96 & $19-90$ & Tropical (BR 106 Tuxpeño) \\
\hline UFG97 & 40.412 & Mista - predominância de tropical \\
\hline UFG98 & 41.005 & Mista - predominância de temperado \\
\hline UFG99 & PR94A 419-27 & Tropical (CIMMYT) \\
\hline UFG100 & $42-85$ & Mista - predominância de temperado \\
\hline UFG101 & 40.426 & Mista - predominância de tropical \\
\hline UFG102 & 45.110 & Mista - predominância de tropical \\
\hline UFG103 & 45.235 & Mista - predominância de tropical \\
\hline UFG104 & 48.597 & Mista - predominância de temperado \\
\hline UFG105 & 43.438 & Mista - predominância de temperado \\
\hline UFG106 & 48.598 & Mista - predominância de temperado \\
\hline UFG107 & 48.588 & Mista - predominância de temperado \\
\hline UFG109 & 48.584 & Mista - predominância de temperado \\
\hline UFG110 & 48.589 & Mista - predominância de temperado \\
\hline DAS-1 & Dow AgroScience & Tropical \\
\hline DAS-2 & Dow AgroScience & Tropical \\
\hline DAS-3 & Dow AgroScience & Tropical \\
\hline DAS-4 & Dow AgroScience & Tropical \\
\hline DAS-5 & Dow AgroScience & Tropical \\
\hline DAS-6 & Dow AgroScience & Tropical \\
\hline DAS-7 & Dow AgroScience & Tropical \\
\hline DAS-8 & Dow AgroScience & Tropical \\
\hline DAS-9 & Dow AgroScience & Tropical \\
\hline DAS-10 & Dow AgroScience & Tropical \\
\hline
\end{tabular}


Tabela 6. Designação e origem dos 77 isolados de Cercospora utilizados no estudo de diversidade morfo-genética

\begin{tabular}{|c|c|c|c|}
\hline Isolado & Origem & Isolado & Origem \\
\hline Uber-1 & Uberlândia, MG & $1-6$ & Indianópolis, MG \\
\hline Uber-2 & Uberlândia, MG & $\mathrm{I}-7.1$ & Indianópolis, MG \\
\hline Uber-3 & Uberlândia, MG & $\mathrm{I}-7.2$ & Indianópolis, MG \\
\hline Uber-4 & Uberlândia, MG & $\mathrm{I}-8$ & Indianópolis, MG \\
\hline Uber-5 & Uberlândia, MG & I-9.1 & Indianópolis, MG \\
\hline Uber-6 & Uberlândia, MG & $\mathrm{I}-9.2$ & Indianópolis, MG \\
\hline Uber-7 & Uberlândia, MG & $\mathrm{I}-10$ & Indianópolis, MG \\
\hline Uber-8 & Uberlândia, MG & $\mathrm{I}-11$ & Indianópolis, MG \\
\hline Uber-9 & Uberlândia, MG & $\mathrm{PO}$ & Presidente Olegário, MG \\
\hline Uber-10 & Uberlândia, MG & Tup & Tupaciguara, MG \\
\hline U-1.1 & Unaí, MG & Irai-4.1 & Iraí de Minas, MG \\
\hline$U-1.2$ & Unaí, MG & Ja-1.3 & Jardinópolis, SP \\
\hline$U-2.1$ & Unaí, MG & Ja-3.1 & Jardinópolis, SP \\
\hline$U-2.3$ & Unaí, MG & JB-1.2 & José Bonifácio, SP \\
\hline CD-2.1 & Cachoeira Dourada, MG & JB-1.3 & José Bonifácio, SP \\
\hline CD-2.2 & Cachoeira Dourada, MG & Pira-1.1 & Piracicaba, SP \\
\hline CD-2.3 & Cachoeira Dourada, MG & Pira-4 & Piracicaba, SP \\
\hline CD-3.1 & Cachoeira Dourada, MG & Pira-5 & Piracicaba, SP \\
\hline CD-3.2 & Cachoeira Dourada, MG & Pira-6 & Piracicaba, SP \\
\hline CD-3.3 & Cachoeira Dourada, MG & Pira-7 & Piracicaba, SP \\
\hline I-1 & Indianópolis, MG & Pira-7.1 & Piracicaba, SP \\
\hline $\mathrm{I}-2.2$ & Indianópolis, MG & Pira-9.3 * & Piracicaba, SP \\
\hline I-2.3 & Indianópolis, MG & Pira-10.1 & Piracicaba, SP \\
\hline I-3 & Indianópolis, MG & Pira-11.1 & Piracicaba, SP \\
\hline I-3.2 & Indianópolis, MG & Pira-11.2 & Piracicaba, SP \\
\hline I-4.1 & Indianópolis, MG & Pira-11.3 & Piracicaba, SP \\
\hline $1-4.2$ & Indianópolis, MG & Pira-12 & Piracicaba, SP \\
\hline $1-5$ & Indianópolis, MG & Gua-2.2 * & Guaíra, SP \\
\hline
\end{tabular}


Tabela 6. Designação e origem dos 77 isolados de Cercospora utilizados no estudo de diversidade morfo-genética

\begin{tabular}{llll}
\hline Isolado & \multicolumn{1}{c}{ Origem } & Isolado & \multicolumn{1}{c}{ Origem } \\
\hline Gua-5 & Guaíra, SP & RV-1 & Rio Verde, GO \\
SJBV & São João da Boa Vista, SP & Cris-1 & Cristalina, GO \\
Mig-1 & Miguelópolis, SP & Cris-2 & Cristalina, GO \\
Mig-2 & Miguelópolis, SP & Cris-3 & Cristalina, GO \\
Mig-3 & Miguelópolis, SP & $5-34^{\star *}$ & Iganga, Uganda - África \\
Mig-4 & Miguelópolis, SP & $5-24^{\star *}$ & Iganga, Uganda - África \\
Mig-5 & Miguelópolis, SP & $19^{\star \star}$ & Oley, Pennsylvania - USA \\
Mig-6 & Miguelópolis, SP & $1-5^{\star *}$ & South Charleston, Ohio - USA \\
Lem & Luis Eduardo Magalhães, BA & $14 B^{\star *}$ & Sharidan, Illinois - USA \\
Castro & Castro, PR & $11 B^{\star *}$ & Sharidan, Illinois - USA \\
Per & Perolândia, GO & & \\
\hline
\end{tabular}

* Isolados de C. sorghi f. sp. maydis

** DNA gentilmente cedidos pelo Prof. Dr. Larry L. Dunkley - Purdue University 
Tabela 8. Produção de cercosporina em meio BDA e média das medidas conidias dos isolados brasileiros de C. zeae-maydis

\begin{tabular}{|c|c|c|c|c|c|}
\hline Isolado & Grupo & Cercosporina $^{1}$ & $\begin{array}{c}\text { Comprimento } \\
(\mu \mathrm{m})^{*}\end{array}$ & $\begin{array}{c}\text { Largura } \\
(\mu \mathrm{m})^{\star}\end{array}$ & $\begin{array}{c}\text { Número de } \\
\text { septos }^{*}\end{array}$ \\
\hline Tup & 1 & 1 & 66,85 & 5,32 & 6,37 \\
\hline U-2.3 & 1 & 2 & 63,73 & 6,58 & 5,23 \\
\hline I-7.1 & 1 & 1 & 60,67 & 6,66 & 5,67 \\
\hline Pira-4 & 1 & 3 & 59,13 & 6,16 & 5,08 \\
\hline U-2.1 & 1 & 2 & 58,51 & 6,58 & 5,08 \\
\hline Pira11.1 & 1 & 3 & 56,12 & 6,32 & 4,05 \\
\hline I-3.2 & 1 & 3 & 55,79 & 5,35 & 3,57 \\
\hline Uber-1 & II & 1 & 55,58 & 6,37 & 4,11 \\
\hline |-4.1 & 1 & 2 & 54,59 & 6,19 & 4,12 \\
\hline $\mathrm{PO}$ & II & 1 & 54,27 & 6,65 & 3,60 \\
\hline I-11 & II & 1 & 53,77 & 1,17 & 4,37 \\
\hline CD-2.2 & 1 & 2 & 53,30 & 5,65 & 3,61 \\
\hline Cris-1 & II & 1 & 53,18 & 6,68 & 4,77 \\
\hline Uber-5 & II & 1 & 52,62 & 5,08 & 4,94 \\
\hline JB-1.3 & 1 & 3 & 52,13 & 5,51 & 3,39 \\
\hline Ja-3.1 & 1 & 1 & 51,93 & 6,07 & 4,43 \\
\hline Pira-1.1 & 1 & 3 & 51,71 & 6,61 & 4,25 \\
\hline Ja-1.3 & I & 2 & 50,67 & 6,53 & 3,95 \\
\hline Cris-3 & II & 1 & 50,48 & 6,39 & 4,45 \\
\hline I-2.2 & 1 & 1 & 50,35 & 6,28 & 4,02 \\
\hline CD-2.3 & 1 & 2 & 50,22 & 5,87 & 3,65 \\
\hline Mig-2 & II & 1 & 50,20 & 6,31 & 3,40 \\
\hline Gua-5 & 1 & 3 & 49,94 & 5,75 & 4,15 \\
\hline I-1 & I & 1 & 49,79 & 6,86 & 3,85 \\
\hline JB-1.2 & I & 4 & 49,16 & 5,34 & 3,50 \\
\hline
\end{tabular}


Tabela 8. Produção de cercosporina em meio BDA e média das medidas conidias dos isolados brasileiros de $C$. zeae-maydis

\begin{tabular}{|c|c|c|c|c|c|}
\hline Isolado & Grupo & Cercosporina $^{1}$ & $\begin{array}{c}\text { Comprimento } \\
(\mu \mathrm{m})^{\star}\end{array}$ & $\begin{array}{l}\text { Largura } \\
\qquad(\mu \mathrm{m})^{\star}\end{array}$ & $\begin{array}{l}\text { Número de } \\
\text { septos* }\end{array}$ \\
\hline$\overline{\text { Per }}$ & II & 1 & 49,14 & 6,93 & 3,35 \\
\hline Pira-12 & I & 3 & 49,10 & 5,74 & 3,88 \\
\hline Castro & II & 1 & 49,06 & 5,74 & 4,41 \\
\hline $1-5$ & I & 1 & 48,94 & 6,08 & 3,83 \\
\hline CD-3.2 & I & 1 & 48,90 & 5,91 & 3,85 \\
\hline Pira-7 & 1 & 1 & 48,87 & 5,77 & 4,00 \\
\hline $\mid-10$ & II & 1 & 48,76 & 7,00 & 3,74 \\
\hline Uber-3 & I & 1 & 48,74 & 5,65 & 3,71 \\
\hline Mig-6 & II & 1 & 48,58 & 6,92 & 4,19 \\
\hline $1-3$ & I & 1 & 48,53 & 6,04 & 3,82 \\
\hline Irai-4.1 & II & 1 & 48,41 & 5,21 & 3,77 \\
\hline Pira-5 & I & 2 & 48,39 & 5,88 & 3,62 \\
\hline Uber-8 & II & 1 & 47,89 & 6,56 & 3,83 \\
\hline CD-3.1 & I & 2 & 47,67 & 5,30 & 3,27 \\
\hline Pira-7.1 & I & 1 & 47,65 & 5,84 & 3,61 \\
\hline Lem & I & 3 & 47,29 & 5,30 & 3,70 \\
\hline Cris-2 & II & 1 & 47,27 & 6,79 & 4,23 \\
\hline U-1.1 & I & 3 & 47,22 & 5,55 & 4,29 \\
\hline Pira-6 & I & 2 & 47,21 & 6,46 & 3,36 \\
\hline Pira-10.1 & I & 3 & 47,17 & 6,95 & 3,45 \\
\hline Pira-11.3 & I & 1 & 47,05 & 6,80 & 3,46 \\
\hline $\mathrm{I}-6$ & I & 1 & 47,04 & 6,41 & 3,95 \\
\hline Mig-4 & II & 1 & 46,82 & 5,26 & 3,43 \\
\hline I-7.2 & I & 1 & 46,08 & 6,15 & 3,58 \\
\hline I-2.3 & I & 2 & 45,88 & 6,17 & 3,53 \\
\hline I-9.2 & II & 1 & 44,63 & 5,85 & 3,64 \\
\hline Uber-10 & II & 1 & 44,55 & 5,62 & 3,30 \\
\hline
\end{tabular}


Tabela 8. Produção de cercosporina em meio BDA e média das medidas conidias dos isolados brasileiros de $C$. zeae-maydis

\begin{tabular}{lccccc}
\hline Isolado & Grupo Cercosporina & $\begin{array}{c}\text { Comprimento } \\
(\mu \mathrm{m})^{*}\end{array}$ & $\begin{array}{c}\text { Largura } \\
(\mu \mathrm{m})^{*}\end{array}$ & $\begin{array}{c}\text { Número de } \\
\text { septos* }^{*}\end{array}$ \\
\hline I-8 & I & 1 & 44,06 & 5,17 & 3,63 \\
Uber-7 & II & 1 & 43,68 & 5,30 & 3,19 \\
Pira-11.2 & I & 3 & 43,13 & 5,57 & 3,32 \\
Uber-9 & II & 1 & 42,94 & 6,13 & 4,04 \\
Uber-2 & II & 1 & 42,03 & 6,12 & 3,77 \\
Uber-4 & II & 1 & 41,84 & 5,40 & 3,68 \\
I-9.1 & II & 1 & 41,78 & 5,94 & 4,10 \\
Uber-6 & II & 1 & 41,51 & 5,49 & 4,21 \\
IN-4.2 & I & 3 & 41,40 & 6,73 & 3,38 \\
Mig-3 & II & 1 & 40,62 & 5,48 & 2,87 \\
Mig-1 & II & 1 & 38,52 & 5,55 & 2,90 \\
U-1.2 & I & 2 & 34,06 & 5,75 & 3,16 \\
\hline
\end{tabular}

* Média de 150 conídios

${ }^{1}$ Produção de cercosporina em meio BDA: 1 = nenhuma pigmentação; 2 = pouca produção com a coloração do meio apenas ao redor da colônia fúngica; 3 = produção considerável da toxina com coloração do meio atingindo metade da extensão da placa; 4 = grande produção de cercosporina com a placa completamente colorida pelo pigmento. 


\section{REFERÊNCIAS BIBLIOGRÁFICAS}

AGROCERES. Guia Agroceres de sanidade. São Paulo: Sementes Agroceres, 1996. 72p.

ANDERSON, J.G.; SMITH, J.E. The production of conidiophores and conidia by newly germinated conida of Aspergillus niger (microcycle conidiation). Journal of General Microbiology, v.69, p.185-197, 1971.

ANSARI, N.A.; KHAN, M.W.; MUHEET, A. Effect of some factors on growth and sporulation of Alternaria brassicae causing Alternaria blight of rapeseed and mustard. Acta Botanica Indica, v.17, p.49-53, 1989.

APPEL, D.M.; GORDON, T.R. Intraspecific variation within populations of Fusarium oxysporum based on RFLP analysis of the intergenic spacer region of the rDNA. Experimental Mycology, v.19, p.120-128,1995

BAIR, W.; AYRES, J.E. Variability in isolates of Cercospora zeae-maydis. Phytopathology, v.76, p.129-132, 1986. 
BANDYOPADHYAY, R.; MUGHOGHO, L.K.; MANOHAR, S.K.; SATYANARAYANA, M.V. Stroma development, honeydew formation, and conidial production in Claviceps sorghi. Phytopathology, v.80, p.812-818, 1990.

BAYERS, W.; AYERS, J.E. Variability in isolates of Cercospora zeae-maydis. Phytopathology, v.76, p.129-132, 1986.

BECKMAN, P.M.; PAYNE, G.A. Eternal growth, penetration, and development of Cercospora zeae-maydis in corn leaves. Phytopatology, v.72, p.810-815, 1982.

BECKMAN, P.M.; PAYNE, G.A. Cultural techniques and conditions influencing growth and sporulation of Cercospora zeae-maydis and lesion development in corn. Phytopathology, v.73, p.286-289, 1983.

BORIE, B.; JACQUIOT, L.; JAMAUX-DESPRÉAUX, LARIGNON, P.; PÉROS, J.P. Genetic diversity in populations of the fungi Phaeomoniella chlamydospora and Phaeoacremonium aleophilum on grapevine in France. Plant Pathology, v.51, p.85-96, 2002.

BRUNELLI, K.R.; ATHAYDE SOBRINHO, C.; CAVALCANTI, L.S.; FERREIRA, P.T.O. Análises microscópicas da germinação de Diplodia macrospora. Fitopatologia Brasileira, v.27, p.88, 2002. Suplemento. Apresentado ao XXXIV Congresso Brasileiro de Fitopatologia, Recife, 2002 - Resumo.

BRUNELLI, K.R.; KIMATI, H.; FOGAÇA, J.; CAMARGO, L.E.A. Procedimentos para isolamento e esporulação de Cercospora zeae-maydis. Fitopatologia Brasileira, v.26, p.323, 2001. Apresentado ao XXXIII Congresso Brasileiro de Fitopatologia, São Pedro, 2001 - Resumo. 
BUBECK, D.M.; GOODMAN, M.M.; BEAVIS, W.D.; GRANT, D. Quantitative trait loci controlling resistance to gray leaf spot in maize. Crop Science, v.33, p.838-847, 1993.

BURDON, J.J.; ROELFS, A.P. Isozyme and virulance variation in assexually reproducing population of Puccinia graminis and $P$. recondita on wheat. Phytopathology, v.75, p.907-913, 1985.

CALLAHAN, T.M.; ROSE, M.S; MEADE, M.J.; EHRENSHAFT, M.; UPCHURCH, R.G. CFP, the putative cercosporin transporter of Cercospora kikuchii, is required for wild type cercosporin production, resistance, and virulence on soybean. Molecular Plant Microbe Interections, v. 12, p.901-910, 1999.

CAMPBELL, C.L.; MADDEN, L.V. Introduction to plant disease epidemiology. New York: John Willey, 1990. 532p.

CARSON, M.L.; GOODMAN, M.M.; WILLIAMSON, S.M.; HARALAMBOUS, V.; NYANAPAH, J.O. Pathogen variability as a potencial cause of genotype $x$ environment interaction in maize gray leaf spot trials. Phytopathology, v.87, p.S15, 1997. Suplemento. Apresentado ao Annual Meeting of Americal Phytopatological Society, San Diego, 1997 - Abstract.

CARSON, M.L.; GOODMAN, M.M.; WILLIAMSON, S.M. Variation in aggressiveness among isolates of Cercospora from maize as a potential cause of genotype-environment interaction in gray leaf spot trials. Plant Disease, v.86, p.1089-1093, 2002.

CHUPP, C. A monograph of the fungus genus Cercospora. New York: The Ronald Press, 1953. 667p. 
CHUPP, C.; SHERF, A.F. Vegetable disease and their control. New York: The Ronald Press, 1960. 232p.

CLEMENTS, M.J.; DUDLEY, J.W.; WHITE, D.G. Quantitative trait loci associated with resistance to gray leaf spot of corn. Phytopatology, v.90, p.1018-1025, 2000.

COATES, S.T.; WHITE, D.G. Sources of resistance to gray leaf spot of corn. Plant Disease, v.78, p.1153-1155, 1994.

COATES, S.T.; WHITE, D.G. Inheritance of resistance to gray leaf spot in crosses involving selected resistance inbred lines of corn. Phytopathology, v.88. p.972-982, 1998.

COÊLHO, R.M.S.; CASTRO, H.A.; MENEZES, M. Esporulação de Phomopsis e Phoma em diferentes meios de cultura e condições de temperatura e luminosidade. Summa Phytopathologica, v.23, p.176-180, 1997.

CORTAT, M.; TURIAN, G. Conidiation of Neurospora crassa in submerged culture without mycelial phase. Archives of Microbiology, v.95, p.305-309, 1974.

CRESTE, S.; TULMANN NETO, A.; FIGUEIRA, A. Detection of single sequence repeat polymorfisms in denaturing polyacrylamide sequencing gels by silver staining. Plant Molecular Biology Reporter, v.19, p.299-306, 2001. 
CRUZ, C.D. Programa Genes versão Windows: Aplicativo computacional em genética e estatística. Viçosa: Editora UFV, 2001. 648p.

DAUB, M.E. Cercosporin, a photosensitizing toxin from Cercospora species. Phytopathology, v.72, p.370-374, 1982.

DAUB, M.E.; EHRENSHAFT, M. The photoactivated Cercospora toxin cercosporin: contribution to plant disease and fundamental biology. Annual Review of Phytopathology, v.38, p.461-490, 2000.

DE NAZARENO, N.R.X.; LIPPS P.E.; MADDEN, L.V. Survival of cercospora zeae-maydis in corn residue in Ohio. Plant Disease, v.76, p.560-563, 1992.

DI RIENZO, M.A.; BONAMICO, N.C.; SALERNO, J.C.; IBANEZ, M.M.; GESUMARIA, J.J. Inheritance of resistance to Mal de rio Cuarto (MRC) disease in Zea mays (L.). Journal of Agricultural Science, v.139, p.47-53, 2002.

DONAHUE, P.J; STROMBERG, E.L.; MYERS, S.L. Inheritance of reaction gray leaf spot in a diallel cross of 14 maize inbreds. Crop Science, v.31, p.926931, 1991.

DUNKLE, L.D.; CARSON, M.L. Genetic variation in Cercospora and the potential impact on selecting for resistance to gray leaf spot of corn. In: $53^{\text {rd }}$ annual corn \& sorghum research conference, Chicago, 1998. Anais. Chicago: Amercian seed trade association, 1998, p.30-35. 
DUNKLE, L.D.; LEVY, M. Genetic relatedness of African na United States populations of Cercospora zeae-maydis. Phytopathology, v.90, p.486-490, 2000.

EHRENSHAFT, M.; JENNS, A.E.; CHUNG, K.R.; DAUB, M.E. SOR1, a gene required for photosensitizer and singlet oxygen resistance in Cercospora fungi, is highly conserved in divergent organisms. Molecular Cell, v.1, p.603609, 1998.

FAJOLA, A.O. Cercosporin, a phytotoxin from Cercospora spp. Physiology Plant Pathology, v.13, p.157-164, 1978.

FANCELLI, A.L. Plantas alimentícias: guia prático para aulas, estudos e discussões. Piracicaba: Centro Acadêmico "Luiz de Queiroz",1986. 131p.

FANTIN, G.M.; BRUNELLI, K.R.; RESENDE, I.C.; DUARTE, A.P. A mancha de cercospora do milho. IAC. Boletim Técnico, 192. Campinas: IAC, 201. 19p.

FERNANDEZ, F.A.; GLAWE, D.A.; SINCLAIR, J.B. Microcycle conidiation and nuclear behavior during conidiogenesis in Cercospora kikuchii. Mycologia, v.83, p.752-757, 1991.

FERREIRA, M.E.; GRATTAPAGLIA, D. Introdução ao uso de marcadores RAPD e RFLP em análises genéticas. Brasília: EMBRAPA, CENARGEN, 1995. 220p.

FREPPON, J.T.; LIPPS, P.E.; PRATT, R.C. Characterization of the chlorotic lesion response by maize to Cercospora zeae-maydis. Plant Disease, v.78, p.945-949, 1994. 
FREPPON, J.T.; PRATT, R.C.; LIPPS, P.E. Chlorotic lesion response of maize to Cercospora zeae-maydis and its effect on gray leaf spot disease. Phytopathology, v.86, p.733-738, 1996.

GEVERS, H.O; LAKE, J.K. HOHLS, T. Diallel cross analysis of resistance to gray spot in maize. Plant Disease, v.78, p.379-383, 1994.

GRIFFIN, D. H. Fungal physiology. New York: Wiley-Liss. 1994. 458p.

HANADA, R.E.; GASPAROTTO, L.; PEREIRA, J.C.R. Esporulação de Mycosphaerella fijiensis em diferentes meios de cultura. Fitopatologia Brasileira, v.27, p.170-173, 2002.

HANLIN, R.T. Microcycle conidiation - a rewiew. Mycoscience, v.35, p.113-123, 1994.

HAWKER, L.E. The physiology of reproduction in fungi. Cambridge: Cambridge University Press, 1957. 128p.

HILLIS, D.M.; DIXON, M.T. Ribossomal DNA: Molecular evolution and phylogenetic inference. Quarterly Review of Biology, v.66, p.441-453, 1991.

HSIEH, T.F.; HUANG, J.W.; HSIANG, T. Light and scanning electron microscopy studies on the infection of oriental lily leaves by Botritis elliptica. European Journal of Phytopatology, v.107, p.571-581, 2001.

JENNS, A.E.; DAUB, M.E.; UPCHURCH, R.G. Regulation of cercosporin accumulation in culture by medium and temperature manipulation. Phytopatology, v.79, p.213-219, 1989. 
KITAJIMA, E.W.; LEITE, B. Curso introdutório de microscopia eletrônica de varredura. Piracicaba: NAP/MEPA, 1997. 46p. (Apostila do $25^{\circ}$ curso de microscopia eletrônica de varredura).

KROPP, B.R.; HOOPER, G.R.; HANSEN, T.R.; BINNS, M.; THOMSON, S.V. Initial events in the colonization of dryer's woad by Puccinia thlaspeos. Canadian Journal of Botany, v.77, p.843-849, 1999.

KUMAAR, S.; TAMURA, K.; JAKOBSER, I; NEI, M. MEGA II: Molecular Evolutionary Genetic Analysis. Wisconsin. Bioinformatic, v.17, p.1244-1245, 2001.

KUMAR, V.; GUPTA, V.P. Scanning electron microscopy of ingress and infection of Helminthosporium tetramera in mulberry. Indian Phytopathology, v.55, p.306-307, 2002.

LAPAIRE, C.L.; DUNKLE, L.D. Microcycle conidiation in Cercospora zeaemaydis. Phytopathology, v.93, p.193-199, 2003

LATTERELL, F.M.; ROSSI, A. Gray leaf spot of corn: a disease on the move. Plant Disease, v.67, n.8, p.842-847, 1983.

LEANDRO, L.F.S.; GLEASON, M.L; NUTTER, F.W.; WEGULO, S.N.; DIXON, P.M. Germination and esporulation of Colletotrichum acutatum on symptomless strawberry leaves. Phytopathology, v.91, p.659-664, 2001.

LEVY, M.; CORREA-VICTORIA, F.J.; ZEIGLER, R.S.; XU, S.; HAMER, J.E. Genetic diversity of the rice blast fungus in a disease nursey in Colombia. Phytopathology, 83, p.1427-1433, 1993. 
LIPPS, P.E. Gray leaf spot epiphytotic in Ohio corn. Plant Disease, v.71, p.281, 1987.

LUKENS, R.J. Photo-inhibition of sporulation in Alternaria solani. American Journal of Botany, p.50, p.721-724, 1963.

MARROF, M.A.S.; ZUE, Y.G.; XIANG, Z.X.; STROMBERG, E.L.; RUFENER, G.K. Identification of quantitative trait loci contolling resistance to gray leaf spot disease in maize. Theoretical and Applied Genetics, v.93, p.539-546, 1996.

MAJER, D.; LEWIS, B.G.; MITHEN, R. Genetic variation among field isolates of Pyrenopeziza brassicae. Plant Pathology, v.47, p.22-28, 1998.

MAJER, D.; MITHEN, R.; LEWIS, B.G.; VOS, P.; OLIVER, R.P. The use of AFLP fingerprinting for the detection of genetic variation in fungi. Mycological Research, v.100, p.1107-1111, 1996.

MEREDITH, D.S. Significance of spore release and dispersal mechanisms in plant disease epidemiology. Annual Review of Phytopatholgy, v.11, p.313343, 1973.

MILLER, R.N.; QUEZADO-SOARES, A.M.; LOPES, C.A. Molecular comparison of Fusarium population causing eumartii wilt and dry rot of potato in Brasil. Fitopatologia Brasileira, v.24, p.149-155, 1999.

MOORE-LANDECKER, E. Fundamentals of the fungi. New Jersey: PrenticeHall, Inc. 1972. 158p. 
MUELLER, U.G.; WOLFENBARGER, L.L. AFLP genotyping and fingerprinting. Tree, v.14, p.389-394, 1999.

MUNKVOLD, G.P.; MARTINSON, C.A.; SHRIVER, J.M.; DIXON, P.M. Probabilities for profitable fungicide use against gray leaf spot in hybrid maize. Phytopathology, v.91, p.477-484, 2001

NAGEL, C.M. Conidial production in species of Cercospora in pure culture. Phytopathology, v.24, p.1101-1110, 1934.

NIELSEN, K.; JUSTESEN, A.F.; JENSEN, D.F.; YOHALEM, D.S. Universally primed polymerase chain reaction alleles and internal transcribed spacer restriction fragment length polymorphisms distinguish two subgroups in Botritis aclada distinct from B. byssoidea. Phytopathology, v.91, p.527-533, 2001.

O'DONNEL, K.; GRAY, L.E. Phylogenetic relationships of the soybean sudden death syndrome pathogen Fusarium solani f. sp. phaseoli inferred from rDNA sequence data and PCR primers for its identification. Molecular Plant Microbe Interactions, v.8, p.709-716.

PEJIC, I.; AJMONE-MARSAN, P.; MORGANTE, M.; KOZUMPLICK, V.; CASTIGLIONI, P.; TARAMINO, G.; MOTTO, M. Comparative analysis of genetic similarity among maize inbred lines detected by RFLPS, RAPDs, SSRs, and AFLPs. Theoretical and Applied Genetics, v.97, p.1248-1255, 1998.

QUEIROZ, F.M.; MENEZES, M. Efeito de meios de cultura e do regime de luz na esporulação de Cercospora nicotianae. Fitopatologia Brasileira, v.18, p.545-547, 1993. 
RATHAIAH, Y. Stomatal tropism of Cercospora beticola in sugarbeet. Phytopathology, v.67, p.358-362, 1977.

READER, U.E.; BRODA, P. RAPD preparation of DNA from filamentous fungi. Letters in Applied Microbiology, v.1, p.17-20, 1985.

RINGER, C.E.; GRYBAUSKAS, A.P.; Infection cycle components and disease progress of gray leaf spot on field corn. Plant Disease, v.79, p.24-28, 1995.

ROANE, C.W. observations on corn disease in Virginia from 1947 to 1950. Plant Disease Report, v.34, p.394-396, 1950.

ROSSIER, C.; TON-THAT, T.C.; TURIAN, G. Microcyclic microconidiation in Neurospora crassa. Experimental Mycology, v.1, p.52-62, 1977.

ROTEM, J.; BICKLE, W.; KRANZ, J. Effect on environment and host on sporulation of Alternaria macrospora in cotton. Phytopathology, v.79, p.263266, 1989.

SALEH, A.A.; ZELLER, K.A.; ISMAEL, A.S.M; FAHMY, Z.M.; EL-ASSIUTY, E.M.; LESLIE, J.F. Amplified fragment length polymorphism diversity in Cephalosporium maydis from Egypt. Phytopathology, v.93, p.853-859, 2003

SAMUELS, G.J.; SEIFERT, K.A. The impact of molecular characters on systematics of filamentous ascomycetes. Annual Review of Phytopathology, v.33, p.37-67, 1995.

SANTOS, C.; REETZ, E.; CORRÊA, S.; BELING, R.R.; KIST, B.B. Anuário brasileiro do milho 2003. Santa Cruz: Gazeta Santa Cruz, 2003. 136p. 
SAS INSTITUTE. SAS System. Cary, 1993. 18v.

SHANKAR, M.; COWLING, W.A.; SWEETINGHAM, M.W. Histological observation of latent infection and tissue colonization by Diaporthe toxica in resistant and susceptible narrow-leafed lupins. Canadian Journal of Botany, v.76, p.1305-1316, 1998.

SHIM, W.B.; DUNKLE, L.D. Identification of genes expressed during cercosporin biosynthesis in Cercospora zeae-maydis. Physiological and Molecular Plant Pathology, v.61, p.237-248, 2002.

SHURTLEFF, M.C. Compendium of corn disease. 2. ed. Urbana: American Phytopathological Society, 1980. 105p.

SILVA, H.P. Incidência de doenças fúngicas na "safrinha". In IV seminário sobre a cultura do milho "Safrinha", Campinas, 1997. Anais. Campinas: IAC/CDV, 1997. p. 81-86.

SOMAI, B.M.; DEAN, R.A.; FARNHAM, M.W.; ZITTER, T.A.; KEINATH, A. Internal transcribed spacer regions 1 and 2 and random amplified polymorphic DNA analysis of Didymella bryoniae and related Phoma species isolated from cucurbits. Phytopathology, v.92, p.997-1004, 2002.

STAVELY, J.R.; NIMMO, J.A. Relation of $\mathrm{pH}$ and nutrition to growth and sporulation of Cercospora nicotianae. Phytopathology, v.58, p.1372-1376, 1968. 
STEINKAMP, M.P.; MARTIN, S.S.; HOEFERT, L.L; RUPPEL, E.G. Ultrastructure of lesions produced in leaves of Beta vulgaris by cercosporin, a toxin from Cercospora beticola. Phytopathology, v.71, p.1272-1281, 1981

STRANDBERG, J.O. Isolation, storage, and inoculum production methods for Alternaria dauci. Phytopathology, v.77, p.1008-1012, 1987.

TEHON, L.R.; DANIELS, E. Notes on parasitic fungi of Illinois. Mycologia, v.17, p.240-249, 1925.

THOMPSON, R.B.; BERGQUIST, G.A.; PAYNE, G.A.; BOWMAN, D.T.; GOODMAN, M.M. Inheritance of resistance to gray leaf spot in maize. Crop Science, v.27, p.243-246, 1987.

TOOLEY, P.W.; GOLEY, E.D.; CARRAS, M.M.; O'NEILL, N.R. AFLP comparisions among Claviceps africana isolates from United States, Mexico, Africa, Australia, India, and Japan. Plant Disease, v.86, p.1247-1252, 2002.

TOOLEY, P.W.; FRY, W.E.; VILLAREAL GONZALEZ, M.J. Isozyme characterization of sexual and assexual Phytophthora infenstans populations. Journal of Heredity, v.76, p.431-435, 1985.

TRIONE, E.J.; LEACH, C.M. Light-induced sporulation and sporogenic substance in fungi. Phytopathology, v.59, p.1077-1083, 1969.

UPCHURCH, R.G.; WALKER, D.C.; ROLLINS, J.A; EHRENSHAFT, M.; DAUB, M.E. Mutants of Cercospora kikuchii altered in cercosporin synthesis and pathogenicity. Applied and Environmental Microbiology, v.57, p.29402945, 1991. 
VAN DE GRAAF, P.; JOSEPH, M.E.; CHARTIER-HOLLIS, J.M.; O'NEILL, T.M. Prepenetration stages in infection of clematis by Phoma clematidina. Plant Pathology, v.51, p.331-337, 2002.

VANDERPLANK, J.E. Disease resistance in plants. 2. ed. Gainesville: Academic Press, 1984. 194p.

VEIGA, P. Cercospora sojina Hara: Obtenção de inóculo, inoculação e avaliação da resistência em soja (Glicine max (L.) Merr.). Piracicaba, 1973. 98p. Dissertação (Mestrado) - Escola Superior de Agricultura "Luiz de Queiroz", Universidade de São Paulo.

VOS, P.; HOGERS, R.; BLEEKER, M.; REIJANS, M.; VAN DE LEE, T.; HORNES, M.; FRIJTERS, A.; POT, J.; PELEMAN, J.; KUIPER, M.; ZABEAU, M. AFLP: a new technique for DNA fingerprinting. Nucleic Acids Research, v.23, p.4407-4414, 1995.

WANG, J.; LEVY, M.; DUNKLE, L.D. Sibling species of Cercospora associated whith gray leaf spot of maize. Phytopathology, v.88, p.1269-1275, 1998.

WARD, J.M.J.; NOWELL, D.C. Integrated management for the control of maize gray leaf spot. Integrated Pest Management Reviews, v.3, p.1-12, 1998

WARD, J.M.J.; STROMBERG, E.L.; NOWELL, D.C.; NUTTER JR., F.W. Gray leaf spot - A disease of global importance in maize production. Plant Disease, v.83, n.10, p.884-895, 1999.

WHITNEY, E.D.; DUFFUS, J.E. Compendium of beet diseases and insects. Urbana: American Phytopathological Society, 1986, p.76. 
ZEIDLER, G.; MARGALITH, P. Modification of the sporulation cycle in Penicillium digitatum (Sacc.). Canadian Journal of Microbiology, v. 19, p.481-483, 1973. 